This is an Open Access version of the article: Vanmaercke $\mathrm{M}$, Poesen $\mathrm{J}$, Broeckx $\mathrm{J}$, Nyssen $\mathrm{J}$. (2014) Sediment Yield in Africa. Earth-Science Reviews 136: 350-368 (+ Appendix).

DOI: $10.1016 / j$.earscirev.2014.06.004

\title{
Sediment Yield in Africa
}

Matthias Vanmaercke ${ }^{1,2 *}$, Jean Poesen ${ }^{1}$, Jente Broeckx¹, Jan Nyssen ${ }^{3}$

\footnotetext{
${ }^{1}$ Division of Geography, Department of Earth and Environmental Sciences, KU Leuven, Heverlee, Belgium

${ }^{2}$ Research Foundation Flanders (FWO), Brussels, Belgium

${ }^{3}$ Department of Geography, Ghent University, Ghent, Belgium

*Corresponding Author: Matthias.Vanmaercke@ees.kuleuven.be; address: Division of Geography, Celestijnenlaan 200e - box 2409, 3001 Heverlee
}

\begin{abstract}
Several studies have compiled and analyzed measured contemporary catchment sediment yield (SY, $\left[\mathrm{t} \mathrm{km}^{-2} \mathrm{y}^{-1}\right]$ ) values for various regions of the world. Although this has significantly contributed to our understanding of SY, Africa remains severely underrepresented in these studies. The objective of this article is therefore: i) to review and compile available SY data for Africa; ii) to explore the spatial variability of these SY data; and iii) to examine which environmental factors explain this spatial variability.

A literature review resulted in a dataset of SY measurements for 682 African catchments from 84 publications and reports, representing more than 8,340 catchment-years of observations. These catchments span eight orders of magnitude in size and are relatively well spread across the continent. A description of this dataset and comparison with other SY datasets in terms of spatial and temporal distribution and measurement quality is provided.

SY values vary between 0.2 and 15,699 $\mathrm{t} \mathrm{km}^{-2} \mathrm{y}^{-1}$ (median: $160 \mathrm{t} \mathrm{km}^{-2} \mathrm{y}^{-1}$, average: $634 \mathrm{t} \mathrm{km}^{-2}$ $\left.\mathrm{y}^{-1}\right)$. The highest $S Y$ values occur in the Atlas region with $S Y$ values frequently exceeding $1,000 \mathrm{t} \mathrm{km}^{-2} \mathrm{y}^{-1}$. Also the Rift Region is generally characterized by relatively high $\mathrm{SY}$ values, while rivers in Western and Central Africa have generally low SY values.

Spatial variation in SY at the continental scale is mainly explained by differences in seismic activity, topography, vegetation cover and annual runoff depth. Other factors such as lithology, catchment area or reservoir impacts showed less clear correlations. The results of these analyses are discussed and compared with the findings from other studies. Based on our
\end{abstract}


results, we propose a simple regression model to simulate SY in Africa. Although this model has a relatively low predictive accuracy (40\%), it simulates the overall patterns of the observed SY values well. Potential explanations for the unexplained variance are discussed and suggestions for further research that may contribute to a better understanding of SY in Africa are made.

Keywords: data compilation; reservoir sedimentation; seismic activity; land use; climate; topography

\section{Table of Contents}

1. Introduction

2. A database of African sediment yield observations

2.1 Data collection and quality assessment

2.2 Data Availability

2.3 Measuring periods, length of records and data quality

2.4 Catchment sizes

3. Observed sediment yields in Africa

4. Explaining the spatial variability of sediment yield in Africa

4.1 Methodology

4.1.1 Delineating catchment boundaries

4.1.2 Parameter selection

4.1.3 Statistical analyses

4.2. Factors controlling sediment yield

4.2.1 Main results

4.2.2 Comparison with other studies

4.3 Simulation of spatial patterns of sediment yield in Africa

4.3.1 An African sediment yield model

4.3.2 Unexplained variance

4.3.3 Spatial patterns of sediment yield in Africa

5. Conclusions

\section{Introduction}

Understanding the factors and processes controlling contemporary catchment sediment yield $\left(\mathrm{SY},\left[\mathrm{t} \mathrm{km}^{-2} \mathrm{y}^{-1}\right]\right.$; i.e. the mass of sediment annually leaving a catchment per unit of catchment 
area) is crucial for our comprehension of global denudation rates, biogeochemical cycles, fluvial sedimentary archives and human impacts on sediment fluxes (e.g. Meybeck, 2003; Walling, 2006; Syvitski and Milliman, 2007). Several studies therefore compiled and analyzed worldwide SY observations (e.g. Jansen and Painter, 1974; Walling and Kleo, 1979; Dedkov and Mozzherin, 1984; Jansson, 1988; Milliman et al., 1995; FAO, 2008; Milliman and Farnsworth, 2011). Despite its size and physiographic variability (Goudie et al., 1996), Africa is clearly underrepresented in these compilations (table 1). So far, the FAO (2008) conducted the largest SY data compilation for Africa (table 1). However, almost half of the 205 African SY observations in this dataset are located in Algeria, Morocco or Lesotho while most other African countries are not or poorly represented (FAO, 2008). Moreover, the few African SY data included in these compilations are mainly for larger river systems $(>10,000$ $\left.\mathrm{km}^{2}\right)$. Smaller catchments $\left(<100 \mathrm{~km}^{2}\right)$ are even more underrepresented (table 1$)$.

The main reason for this under representation is the limited number of African SY observations available. This was already highlighted by Walling (1984). Nonetheless, a large number of SY measurements have been conducted in Africa but were often only published in internal reports, theses, conference proceedings or local research journals. This is illustrated by a few regional or country-wide SY compilations in Africa (e.g. Dunne, 1979; Rooseboom, 1978, Nyssen et al., 2004; Liénou et al., 2005; Balthazar et al., 2012). Whereas these compilation studies are an important step forward, a comprehensive continent-wide compilation of African SY data is currently lacking. As a result, our insight into the spatial patterns of SY in Africa is limited (e.g. Walling and Webb, 1983; Walling, 1984; Milliman and Farnsworth, 2011).

Also our ability to predict SY of African rivers is hampered by this lack of data. Some models have been proposed to predict SY for specific African regions, but they are mostly based on a relatively limited number of catchments and involve large uncertainties when applied to catchments in other regions (e.g. Picouet et al., 2001; Ning Ma, 2006; Haregeweyn et al., 2008; Meshesha et al., 2011; Schmengler, 2011; Balthazar et al., 2012). Furthermore, these studies focus on only a few specific African regions (e.g. the Ethiopian Highlands; Haregeweyn et al., 2008; Meshesha et al., 2011; Balthazar et al., 2012). Also earlier developed SY models remain poorly tested for African conditions, while studies aiming to apply existing SY models to African catchments often report poor model performances and/or high data requirements (e.g. Bouraoui et al., 2005; Syvitski and Milliman, 2007; Balthazar et al., 2012; Bossa et al., 2012; Pelletier, 2012; de Vente et al., 2013). 
It is generally accepted that SY is influenced by catchment area, lithology, topography, land use, reservoir impacts and climatic conditions (e.g. de Vente and Poesen, 2005; Syvitski and Milliman, 2007; Pelletier, 2012). However, the relative importance of these factors in explaining spatial variation in SY is not fully understood as this also depends on the catchments considered. This issue has been raised before and is evident from the fact that different studies often report different factors controlling SY (e.g. Jansen and Painter, 1974; Walling, 1983; Lane et al., 1997; de Vente et al., 2005; de Vente et al., 2006; Syvitski and Milliman, 2007; Haregeweyn et al. 2008; de Vente et al., 2013). Most studies dealing with factors controlling SY focus either on large river basins worldwide (e.g. Syvitski and Milliman, 2007; Pelletier, 2012) or on smaller catchments in a specific region (e.g. Dunne, 1979; Liénou et al., 2005; Haregeweyn et al., 2008). Very few studies consider a wide range of catchment sizes or on regional differences at a continental scale.

Furthermore, tectonic activity is generally not considered as a potential controlling factor of SY (e.g. Milliman and Syvitski, 1992; de Vente and Poesen, 2005; Syvitski and Milliman, 2007; Pelletier, 2012; de Vente et al., 2013) with the exception of some studies in highly tectonically active regions (e.g. Dadson et al., 2003; Hovius et al., 2011). Mostly, it is implicitly assumed that the effects of tectonic activity are either irrelevant or reflected in the catchment topography (e.g. Syvitski and Milliman, 2007). However, recent studies indicate that this is not always the case: spatial variation in soil erosion rates and SY can partly be attributed to spatial differences in seismic activity, even in regions where this activity is relatively limited (e.g. Cox et al., 2010; Portenga and Bierman, 2011; Vanmaercke et al., 2014a; 2014b). Nonetheless, the importance of seismic activity as an explaining factor of SY remains poorly understood. The large variation in land use and climatic conditions in combination with the overall low degree of seismic activity (e.g. Shedlock et al., 2000; ANSS, 2013) make the African continent an interesting case to further investigate the potential role of seismic activity as a controlling factor of SY.

However, understanding the factors controlling SY in Africa is not only of interest from a merely scientific point of view. The rapidly growing population (UN-ESA, 2011) and the projected climate changes (e.g. de Wit and Stankiewicz, 2006) will result in a larger need for dams and reservoirs to respond to the increasing energy and water demands in Africa (e.g. Bartle, 2002; Karekezi \& Kithyoma, 2002; Alhassan, 2009; Vanmaercke et al., 2011a; Wisser et al., 2013). Moreover, population growth and climatic changes have important impacts on the land cover changes of various African regions (e.g. Barnes, 1990; Nyssen et al., 2004; Zhang et al., 2006; Odada et al., 2009). These changes often pose significant threats to the 
sustainable use of available water resources (e.g. Ogutu-Ohwayo et al., 1997; Lewis, 2000; Bruijnzeel, 2004; Nyssen et al., 2004; Odada et al., 2004; Reichenstein et al., 2013). For example, numerous constructed or planned water reservoirs in Africa face important capacity losses due to high siltation rates (e.g. Kabell, 1984; Liebe et al., 2005; Haregeweyn et al., 2006; Adwubi et al., 2009; Amegashie et al., 2011; Baade et al., 2012). Also many of the Great African Lakes face important ecological problems, related to the input of sediments and sediment-fixed nutrients (e.g. Ogutu-Ohwayo et al., 1997; Odada et al., 2004). Reliable information on the expected SY and its sensitivity to land use or climate changes is therefore crucial for sustainable catchment management and water harvesting projects. However, the lack of SY measurements and our inability to make reliable predictions often impede the design of such projects (e.g. Haregeweyn et al., 2006).

A continent-wide compilation and analysis of SY measurements in Africa could strongly improve our understanding of the factors controlling SY and help addressing these challenges. The objectives of this study are therefore: i) to present and discuss a compilation of measured SY data in Africa, based on an extensive literature review (section 2); ii) to explore the spatial variability of SY (section 3); and iii) to examine which factors best explain the variability in observed SY (section 4).

\section{A database of African sediment yield observations}

\subsection{Data collection and quality assessment}

Based on an extensive literature review of scientific publications, conference proceedings, MSc. and PhD. theses and reports from hydrological and environmental institutes, a database was constructed with measured catchment SY data for African rivers. Only SY data that were derived from measurements at a gauging station or from reservoir siltation rates over a measuring period of at least one year were considered. Each entry in the database corresponds to one catchment for which SY has been measured and contains the original source of the data, the catchment and/or location name, the location of the catchment outlet, the measured SY value, the type of measurement (observation at a gauging station ('GS') or derived from a reservoir sedimentation rate ('R')), the originally reported catchment area, and if available the measuring period. For several entries, the measuring period was not reported but known to be longer than one year. In these cases, the measuring period was indicated as unknown. If available, the coordinates of the catchment outlets were based on the originally reported coordinates. If not, an assessment was made based on information provided in the publication 
and Google ${ }^{\mathrm{TM}}$ Earth. SY observations for which the measuring location could not be estimated were not included in the database.

The compiled SY data was measured and calculated using various techniques and procedures. This has important implications for the analyses of these data. Especially the difference between SY values derived from reservoir siltation and those obtained from gauging station measurements impedes the comparability of SY observations. Earlier studies have shown that SY-estimates based on low-frequency sampling (e.g. Phillips et al., 1999; Moatar et al., 2006) or short (< 5 yr) measuring periods (Vanmaercke et al., 2012) are more likely to underestimate the true sediment yield because they have a higher probability of excluding low-frequency but high-magnitude events. Especially short-term SY values derived from gauging station measurements are susceptible to such underestimations, while SY estimates based on long-term sedimentation rates in reservoirs with high trapping efficiencies often provide more reliable estimates of the average SY (Verstraeten and Poesen, 2002). Moreover, SY estimates derived from reservoir sedimentation rates include both the suspended and bedload, while almost all SY values measured at gauging stations only consider the suspended load. It is therefore likely that observed differences in SY can, for an important part, be attributed to methodological differences.

To account for this, we explicitly considered this difference in measuring method (GS or R) in our analyses. In addition, we assessed the reliability of each SY observation. Based on the (often limited) available information about the applied measuring procedure, the quality of each SY observation was labelled as 'good', 'acceptable', 'poor' or 'unknown'. GS entries classified as 'good' are typically observations for which runoff discharge and sediment concentrations (SC) were measured at least daily (e.g. Walling et al., 2001). 'Acceptable' entries mainly consist of SY values based on daily runoff measurements while SC was measured at least weekly. Also SY observations for which SC values were estimated based on rating curves with at least 50 observations are included in this category (e.g. Carré, 1972). GS-entries based on a lower sampling frequency or based on rating curves with less than 50 observations were classified as having a 'poor' data quality (e.g. Sichingabula, 2000). SY estimates based on sediment deposition rates in reservoirs with a high estimated trapping efficiency (> 90\%) for which the sediment dry bulk density was measured and for which a correction for the trapping efficiency was applied were classified as having a 'good' data quality (e.g. Haregeweyn et al., 2012). Trapping Efficiencies values were estimated using an empirical equation proposed by Brown (1943). SY estimates derived from sedimentation rates in reservoirs with a high trapping efficiency that were corrected for trapping efficiency but for 
which the dry bulk density was not measured were classified as 'acceptable' (e.g. Rooseboom et al., 1992). R-entries that did not meet these criteria or for which it was suspected that the estimated annual sedimentation volume was susceptible to considerable uncertainties were classified as having a 'poor' data quality (e.g. Ndomba, 2011). For 245 entries, no or insufficient information on the measuring method could be found in their source to allow a quality assessment. These entries were labelled as having an unknown data quality (e.g. Milliman and Farnsworth, 2011).

Evidently, also these quality assessments are subject to uncertainties, since also other sources or error can affect the reliability of the SY observations. Nonetheless, earlier studies clearly indicate that the reliability of sediment yield estimates based on measurements at gauging stations is mainly determined by the sediment concentration sampling frequency and/or the number of sediment concentration samples used to establish rating curves (e.g. Phillips et al., 1999; Moatar et al., 2006; Vanmaercke et al., 2010; Delmas et al., 2011). Likewise, the reliability of SY estimates based on reservoir sedimentation rates strongly depends on the trapping efficiency and the (often estimated) dry bulk density of the sediments (e.g. Verstraeten and Poesen, 2002). The criteria used in this study to assess data quality can therefore be expected to consider the most important sources of uncertainty on SYmeasurements.

For many catchments multiple alternative SY estimates exist. Therefore, the database was thoroughly checked for duplicate entries. Two entries were considered as duplicates if they had the same outlet and (hence) the same catchment area. In such case only the SY measurement that was deemed to be the most reliable was selected. When the estimated quality of both entries was equal or unknown, the entry with the longest measuring period was selected. This was done because average SY values based on a short $(<5$ years $)$ measuring period may be susceptible to large (> 100\%) uncertainties (e.g. Olive and Rieger, 1992; Vanmaercke et al., 2012). If also the measuring periods were equal or unknown, the source that provided the most detailed information on the catchment outlet and measuring technique was selected.

\subsection{Data Availability}

An overview of all collected sediment yield data per country and the original sources of the data is given in table 2. In total SY data for 682 catchments in Africa were collected. For 377 of these catchments, SY was measured at gauging stations. For the other 305 catchments, SY was derived from reservoir sedimentation rates. Several African countries have no or only few 
SY data (table 2). For some of these countries, more SY data most likely exists but could not be included because they were reported in documents that could not be retrieved (e.g. SY data for Kenya, reported by Dunne, 1979). The overview of SY data presented in this study therefore remains to some extent incomplete. Nevertheless, it is hitherto the largest SY compilation for Africa (table 1).

Dividing the area of African continent by the number of SY measurements (682) results roughly in one SY observation per $44,300 \mathrm{~km}^{2}$. This remains a relatively low density compared to other regions. A recent compilation of SY data using a similar approach as this study yielded SY measurements for 1,794 catchments in Europe, corresponding to about one observation per $5,700 \mathrm{~km}^{2}$ (Vanmaercke et al., 2011b). Likewise, the USA has at least 1,026 gauging stations where SY was monitored for at least one year (USGS, 2008) and 1,823 reservoirs with sedimentation rate data available (Ackerman et al., 2009). Assuming that a SY value can be calculated for each of these reservoirs, this yields a total of ca. one SY observation per $3,400 \mathrm{~km}^{2}$.

Figure 1 displays the outlet locations of all African catchments for which SY data were collected. This map illustrates clear regional differences in SY data availability. Northwestern, southern and large parts of eastern Africa are densely covered by SY observations, while no or only very few data are available for Central Africa and the Southwest of the continent. To a large extent, the lack of data in some regions can be easily explained by the presence of deserts (i.e. Sahara, Kalahari) or rainforest. Furthermore the availability of SY data (figure 1) closely corresponds to the availability of runoff discharge data (e.g. Hannah et al., 2011) and with the location of large dams and reservoirs in Africa (Lehner et al. 2011; Wisser et al., 2013). The spatial pattern shown in figure 1 therefore most likely reflects the true SY data availability in Africa.

\subsection{Measuring periods, length of records and data quality}

Assuming that SY values with an unknown measuring period are based on only one year of observations, the sum of all measuring periods for all compiled SY data yields a total of minimum 8,340 catchment-years of observations (table 2). A majority of the SY measurements at gauging stations has an unknown or relatively short ( $\leq 5$ years) measuring period (Figure 2). Excluding SY observations with an unknown measuring period, SY measurements at gauging station stations were on average conducted for 6.0 years (minimum: 1 year, median: 4 years, maximum: 54 years). This is considerably shorter than e.g. in Europe where SY at gauging stations were recorded for on average 13.2 years (Vanmaercke et al., 
2011b). SY observations derived from reservoir sedimentation rates generally cover longer periods (figure 2; average: 24.8 years, minimum: 1 year, median: 17 years, maximum: 98 years).

Figure 3 shows that SY measurements at gauging stations started around the 1930s but were mainly made between 1970 and 1990. After the 1990s, the number of GS observations dropped. The number of SY observations derived from reservoir sedimentation rates increases from the 1900s until the first half of the 1970s but then decreases over the next ten years. This sharp decrease can be partly attributed to two publications discussing reservoir sedimentation rates in South-Africa (table 2; Rooseboom, 1978; Rooseboom et al., 1992). Nonetheless, the overall pattern of figure 3 illustrates a strong decrease in SY data availability after the 1990s. Similar trends were observed for SY data in Europe (Vanmaercke et al., 2011b), the number of reservoir sedimentation surveys in the USA (Ackerman et al., 2009) and the number of runoff discharge data worldwide (Vörösmarty, 2002; Hannah et al., 2011) and have been attributed to a worldwide decreased interest in hydrological measurements (e.g. Hannah et al., 2011; Vanmaercke et al., 2011b).

Based on the criteria discussed in section 2.1, about half of the SY observations were evaluated to have a 'good' or 'acceptable' data quality (Figure 4). For 91 of the SY observations, the reliability was expected to be 'poor'. Especially the reliability of GS entries was mostly low or unknown (Figure 4). As discussed in section 2.1, uncertainties on these SY observations are often further increased by the corresponding short measuring period (e.g. Walling, 1984; Olive and Rieger, 1992; Vanmaercke et al., 2012; figure 2).

\subsection{Catchment areas}

Catchment areas for the collected SY data range between 0.02 and $3.8 \times 10^{6} \mathrm{~km}^{2}$ (median: 998 $\mathrm{km}^{2}$, average: $53,128 \mathrm{~km}^{2}$; Figure 5). Less than $22 \%$ of the catchments are smaller than 100 $\mathrm{km}^{2}$, while only $12 \%$ is smaller than $10 \mathrm{~km}^{2}$. Most of these SY observations for smaller catchments were derived from reservoir sedimentation rates (Figure 5). Also SY data compilations for other regions in the world show that smaller catchments are clearly less well represented (e.g. Dedkov and Mozzherin, 1984; Jansson, 1988; USGS, 2008; de Aráujo and Knight, 2005; Vanmaercke et al., 2011b). This is most likely explained by the fact that larger catchments $\left(>100 \mathrm{~km}^{2}\right)$ are more relevant for planning water management at national scales and are therefore better represented in gauging station networks.

Nonetheless, SY data from small catchments are also highly relevant for various purposes. For example, large numbers of micro-dams have been constructed throughout Africa in order 
to increase water availability (e.g. Rockström, 2000; Liebe et al., 2005; Haregeweyn et al., 2006; Adwubi et al., 2009). Reliable estimates of the expected sediment input into reservoirs are crucial when designing and implementing such projects. Smaller catchments are generally also more suitable than larger catchments to study impacts of various environmental conditions on sediment export, since larger catchments often have more heterogeneous characteristics and are commonly less sensitive to land use changes or specific climatic events (e.g. Walling, 1983; Trimble, 1999; Walling, 1999; Parkin et al., 1996; Phillips, 2003; Dearing et al., 2006).

\section{Observed sediment yields in Africa}

The compiled SY observations for African catchments range between 0.2 and $15,700 \mathrm{t} \mathrm{km}^{-2} \mathrm{y}^{-}$ ${ }^{1}$ (median: $160 \mathrm{t} \mathrm{km}^{-2} \mathrm{y}^{-1}$, average: $634 \mathrm{t} \mathrm{km}^{-2} \mathrm{y}^{-1}$ ). However, $\mathrm{SY}$ values derived from reservoir sedimentation rates (median: $256 \mathrm{t} \mathrm{km}^{-2} \mathrm{y}^{-1}$, average $808 \mathrm{t} \mathrm{km}^{-2} \mathrm{y}^{-1}$ ) are generally higher than those obtained from gauging station observations (median: $114 \mathrm{t} \mathrm{km}^{-2} \mathrm{y}^{-1}$, average $493 \mathrm{t} \mathrm{km}^{-2}$ $\mathrm{y}^{-1}$; figure 6). As discussed in section 2.1, SY measurements from gauging stations generally do not include bedload and have a higher probability of underestimating the true SY, which may partly explain this difference.

Nonetheless, this difference may also be attributed to specific catchment characteristics and environmental conditions. For example, SY observations derived from reservoirs are mainly for catchments $<10,000 \mathrm{~km}^{2}$, while most SY data for larger catchments $\left(>10,000 \mathrm{~km}^{2}\right)$ are based on gauging station measurements (Figure 5; Figure 6). In addition, figure 1 indicates important spatial differences in measuring method: most of the SY values derived from reservoir surveys were made in mountainous regions (i.e. the Rift Valley, Southern Africa and the Atlas region), while a majority of the gauging station observations were made in 'lowlands' (e.g. Western Africa). This pattern corresponds well with observed patterns in SY. When we classify all SY observations into three classes that contain each about one third of the SY observations, one can clearly notice that many of the lowest SY observations are located in Western Africa, while Southern and Eastern Africa are generally characterized by higher SY values (Figure 7). The largest SY values were mainly recorded in the Atlas region and in Ethiopia. It is therefore likely that the difference between SY values derived from gauging station observations and those derived from reservoir sedimentation rates (figure 6) to some extent reflect regional differences of SY in Africa. This will be further investigated in section 4 . 


\section{Explaining the spatial variability of sediment yield in Africa}

\subsection{Methodology}

\subsubsection{Delineating catchment boundaries}

For each of the catchments included in the database an attempt was made to delineate the catchment boundaries. This step was necessary to allow the extraction of various catchment properties that potentially explain the spatial variability of SY in Africa. Depending on the size of the catchment and local terrain conditions, catchment boundaries were (in order of preference) delineated from either SRTM 90m DEMs (CGIAR, 2008), the 30 arc-second HydroSHEDS dataset (Lehner et al., 2006) or the $0.5^{\circ}$ STN dataset (Vörösmarty et al., 2000). Catchment areas resulting from this delineation procedure did not always correspond to the catchment area reported in the original data source. These deviations can be attributed to several reasons: uncertainties on the estimated outlet location, errors and inaccuracies in the datasets used to delineate the watershed boundaries, and wrongly reported catchment areas in the original data source. Estimating the reliability of the obtained watershed boundaries therefore involved some expert judgement. However, as a general criterion, only catchments for which the delineated area deviated less than $20 \%$ from the originally reported catchment area and for which we were certain about the outlet location were considered for further analyses.

In total, catchment boundaries could be delineated for 507 of the 682 catchments (figure 8). The median deviation of the delineated area from the originally reported catchment area was 2.6\%. The spatial distribution of the catchments for which the catchment boundaries could be delineated corresponds closely to the overall availability of SY data in Africa (compare figure 8 and figure 1). The 175 catchments for which the boundaries could not be accurately delineated were not considered in our further analyses.

\subsubsection{Parameter selection}

Several catchment characteristics were derived for each catchment for which the catchment boundaries could be delineated (section 4.1.1). These characteristics describe the area, topography, lithology, seismic activity, climatic conditions and land use of the catchments (table 3). Most of these variables or similar ones have also been used in previous studies on spatial variation in SY or long-term erosion rates at the catchment scale (e.g. Montgomery and Brandon, 2002; Syvitski and Milliman, 2007; de Vente et al., 2011; Portenga and Bierman, 2011). In addition, we included variables to indicate whether a catchment is potentially influenced by large reservoirs (i.e. reservoirs included in the earlier published 
GranD database; Lehner et al., 2011) and whether the SY measurement corresponding to the catchment was derived from gauging station measurements or reservoir sedimentation rates (table 3). Although more variables can be included, the variables listed in table 3 were considered to be the most meaningful in the framework of this study. Several other variables (e.g. average height of the catchment, different measures to quantify land use) were initially included but yielded no different results.

A comparison of environmental characteristics between the 507 selected catchments (section 4.1.1) and the African continent shows that, although some differences in distribution exist, both cover the same range for most of the considered characteristics (figure 9). This indicates that the SY data used in this study are representative for the African continent.

\subsubsection{Statistical analyses}

The relevance of these variables in explaining differences in SY was explored by means of Pearson (partial) correlation coefficients. Partial correlation measures the degree of association between two variables, with the effect of other controlling variables removed (Fisher, 1924; Steel and Torrie, 1960). These (partial) correlation coefficients were calculated based on the log-transformed SY values. Where relevant, also log-transformed versions of the selected parameters (section 4.1.2) were considered in the analyses. A similar approach was followed in earlier studies aiming to identify the factors controlling SY or erosion rates (e.g. Aalto et al., 2006; de Vente et al., 2011; Portenga and Bierman, 2011).

In addition, the potential importance of the considered parameters (table 3) in explaining SY was explored by stepwise regressions, a commonly applied method where the selection of predictive variables is carried out by an automated procedure (Draper and Smith, 1998; Verstraeten and Poesen, 2001). The procedure works by generating an initial model and then evaluating (based on an F-statistic) if adding any of the potential variables would significantly increase the explanatory power of the model. If so, the variable is added. Likewise, it is checked if removing any of the included variables would result in a significant decrease of explanatory power. If not, the variable is removed again. The procedure ends when no single step further improves the model (Mathworks, 2013).

To obtain sufficiently robust results, this stepwise regression procedure was not applied to the entire dataset but to 10,000 randomly selected subsets containing between 30 and $70 \%$ of the original 507 catchments. This resulted in 10,000 different stepwise regression models. Evaluating the frequency with which variables were included in these models, allowed assessing the overall importance of these variables for explaining spatial differences in SY. 


\subsection{Factors controlling sediment yield}

\subsubsection{Main results}

Of all variables considered (table 3), PGA shows the strongest correlation with the natural logarithm (ln) of SY (table 4). PGA (i.e. the expected Peak Ground Acceleration with an exceedance probability of $10 \%$ in 50 years; Shedlock et al., 2000) relates to the probability that an earthquake causes ground movement in the catchment and is a proxy for the degree of seismic activity in a catchment. Based on figure 10a, one can argue that this correlation is mainly attributable to one observation with a high SY and a PGA-value of $3.1 \mathrm{~m} \mathrm{~s}^{-2}$ (i.e. the SY of the Allalah river near Sidi Akacha, Algeria; FAO, 2008). However, this catchment has very little influence on the regression (removing this observation from the regression yields the following equation: $\mathrm{SY}=54.4 \mathrm{e}^{1.67 \mathrm{PGA}} ; \mathrm{R}^{2}=0.16 ; \mathrm{p}<0.0001 ; \mathrm{n}=506$ ). Overall, the distribution of PGA values for the considered catchments agrees well with the distribution of PGA in Africa (figure 9; Shedlock et al., 2000).

Also the variables used to characterise topography generally show significantly positive correlations with $\ln (\mathrm{SY})$ (table 4). Of all topographic measures, the natural logarithm of MLR (Mean Local Relief, i.e. a robust proxy for catchment slope, see table 3) shows the strongest correlation with $\ln (\mathrm{SY})$ (figure 10b). Likewise, lithology (quantified by the scoring variable L; see table 3) show a significant and positive correlation with $\ln (\mathrm{SY})$ (table 4; figure 10c). Land use, expressed as the areal fraction of tree cover (TreeCover; Defries et al., 2000) shows a significantly negative correlation with the natural logarithm of SY (table 4; figure 10d). Since TreeCover represents a fraction and not an absolute value, this variable was not logarithmically transformed. Also catchment area correlates negatively with SY (figure 6), as do most of the considered climatic parameters (table 4; figure 10e and 10f). Variables that express the intra-annual variability in rainfall and runoff (i.e. VarP and VarRo) did not show significant correlations with $\ln (\mathrm{SY})$.

Evidently, all these correlations should be interpreted with care, since several of the considered catchment characteristics are also inter-correlated (table 4). For example, PGA shows significant correlations with L, MLR and several other topographic parameters. Likewise, rainfall and rainfall erosivity correlate negatively with many of the topographic measures. As earlier studies demonstrated, disentangling the importance of individual variables in explaining SY is often difficult (e.g. Verstraeten and Poesen, 2001; de Vente et al., 2011; Portenga and Bierman, 2011; Vanmaercke et al., 2014a and 2014b). Nonetheless, some insight can be obtained from the partial correlation coefficients, i.e. the correlation 
between two variables that remains after correcting for one or more controlling variables (see section 4.1.3). Table 5 lists the partial correlation coefficients of the considered variables after removing the effect of all other variables that relate to other factors (see table 3 ). These partial correlation coefficients show that seismic activity (expressed as PGA or $\ln (\mathrm{PGA})$ ) remains clearly correlated with $\ln (\mathrm{SY})$ after controlling for all variables that relate to factors other than tectonics (i.e. area, topography, lithology, climate, land use, reservoir impacts and measuring procedure). This strongly indicates that the observed correlations between SY and seismicity (figure 10a) are not merely a result of inter-correlations with other factors. Likewise, most of the topographic variables and tree cover show significant partial correlations with $\ln (\mathrm{SY})$ (table 5). Contrary to the normal Pearson correlations (table 4, figure 10f), ln (Ro) shows a highly significant positive partial correlation with $\ln (\mathrm{SY})$ after controlling for all variables related to non-climatic factors (table 5). This suggests that also the average annual runoff depth explains some of the observed variation in SY after the effect of other factors is taken into account. On the other hand, other climatic variables and variables related to lithology, catchment size, reservoir impact, measuring procedure and variability in land use only show a weak (often insignificant) partial correlation with $\ln (\mathrm{SY})$ (table 5).

These findings were confirmed by the stepwise regression models applied to 10,000 randomly selected subsets of catchments (see section 4.1.3). Of all considered variables, TreeCover and PGA were selected in more than $98 \%$ of all cases as an explanatory of SY (figure 11). $\ln (\mathrm{MLR})$ was selected in $87 \%$ of the cases, followed by the natural logarithm of the annual runoff depth (68\%) and the measuring method (64\%). All other variables were only selected for less than half of the models (figure 11).

\subsubsection{Comparison with other studies}

Most of these results concur with findings from other studies exploring the factors controlling SY and erosion rates. For example, the strong topographic control on SY has been identified in several studies (e.g. Milliman and Syvitski, 1992; Montgomery and Brandon, 2002; Aalto et al., 2006; Portenga and Bierman, 2011). Likewise, negative relationships between vegetation cover and SY or erosion rates have been reported before (e.g. Bednarczyk et al., 1996; Vanacker et al., 2007; Nadal-Romero et al., 2011; Portenga and Bierman, 2011).

While it is often expected that SY decreases with catchment area due to an increased probability of sediment deposition, previous studies pointed out that such relationships need to be interpreted with care as they are often, at least partly, spurious and a result of intercorrelations between A and other catchment properties (e.g. Walling, 1983; Verstraeten and 
Poesen, 2001; de Vente et al., 2007; Vanmaercke et al., 2011b). Also in this case, SY shows a significant negative correlation with A (figure 6), which becomes insignificant after controlling for the effects of other factors (table 5). Likewise, $\ln (\mathrm{A})$ was chosen as an explanatory variable of $\ln (\mathrm{SY})$ in less than half of the stepwise regression models (figure 11). This indicates that the negative trend between SY and A for African catchments can be mainly attributed to the overall lower topography and degree of seismic activity in larger catchments compared to smaller catchments (table 4) and that catchment area itself is of relatively limited importance for explaining spatial variability in SY.

Also the poor correlations between $\ln (\mathrm{SY})$ and the considered climatic variables concurs with findings of earlier studies. Although it can be expected that higher rainfall depth and erosivity would result in higher SY values, such trends are often not apparent for large datasets at the global or continental scale, due to the overriding effect of other parameters or interactions between rainfall and vegetation cover (e.g. Walling and Kleo, 1979; Jansson, 1988). Also Syvitski and Milliman (2007) did not detect any meaningful correlation between rainfall measures and the sediment load of rivers at a global scale and indicated that average air temperature might be a more meaningful measure of climatic impacts on SY. However, we observed no such effect (table 5). The fairly limited range of temperatures for our African dataset might explain this.

Also catchment runoff was found to have a significant but fairly limited impact on the spatial variability of SY (table 5; figure 11). Likewise, this is in line with other studies reporting that runoff has only a relatively limited impact on average SY at regional or global scales (e.g. Aalto et al., 2006; Syvitski and Milliman, 2007; Vanmaercke et al., 2014a). It has been argued that temporal variability in rainfall, runoff and (linked to this) seasonal changes in vegetation cover can have an important impact on the sediment load of rivers (Walling and Webb, 1982; Hudson, 2003; Morehead et al., 2003; Moliere et al., 2004; Markus and Demissie 2006; Alexandrov et al., 2007; Vanmaercke et al., 2010). However, none of the three considered variables expected to reflect seasonal changes in rainfall (VarP), runoff (VarRo) or vegetation cover (VarNDVI) showed a convincing correlation with SY (table 4 and 5; figure 11). This may be attributed to the large uncertainties associated with these measures, as these provide only a rudimentary estimate of the seasonal fluctuations and not necessarily of the occurrence of flood events. These measures might be insufficient to reflect the often complex feedbacks between changes in climate, vegetation cover and sediment dynamics (Morehead et al., 2003; Vanmaercke et al., 2012). It could also indicate that, while very relevant for understanding 
sediment dynamics at local scales, temporal variability in rainfall, runoff or vegetation is less important for understanding spatial patterns of average SY values at the continental scale.

The fact that we did not detect an impact of upstream reservoirs on the spatial variability of SY (table 4 and 5; figure 11) may be explained by the similar reasons. It is well known that upstream reservoirs can significantly reduce SY (e.g. Vörösmarty et al., 2003; Syvitski et al., 2005; Walling, 2006). The lack of a clear correlation in our study may therefore be a result of the oversimplified manner with which the influence of reservoirs was evaluated (table 3 ). Due to limitations in the available data, we only considered large reservoirs (Lehner et al., 2011) while also smaller ponds and reservoirs may have a significant impact on SY (e.g. Smith et al., 2002). Furthermore, our approach does not take into account the location of the reservoirs within the catchment, their trapping efficiency or the fact that some reservoirs were constructed after the SY measuring period. Nevertheless, it is also possible that the effects of reservoirs on SY is rather limited compared to other factors. Reservoir construction can easily lead to reductions in SY of a factor five (e.g. Walling, 2006). Nonetheless, such decreases remain relatively limited compared to the six orders of magnitude variation in SY for Africa (figure 6). Moreover, such reduction due to reservoir construction is often compensated for by a (re)activation of sediment sources, resulting in a quickly decreasing impact on SY downstream of the reservoir (e.g. Phillips, 2003).

Likewise, lithology explained little of the variation in SY (table 5; figure 10c; figure 11). This too might be attributed to the fact that the lithology scoring variable used provides only a rough estimate of the erodibility (table 3). Furthermore, the erodibility of rocks is also strongly controlled by the occurrence of fractures (e.g. Selby, 1980; Molnar et al., 2007; Koons et al., 2012), which are not considered by the scoring variable used. More detailed lithological descriptions and their degree of fracturing, as well as information on soil types and textures in the different catchments can be expected to explain more of the observed variability in SY. However, earlier studies also indicated that, compared to other factors such as topography and land use, lithology has often only a secondary control on SY (e.g. Bruijnzeel, 2004; Aalto et al., 2006; Syvitski and Milliman, 2007; Vanmaercke et al., 2014a). Finally, the strong control of seismic activity on seismic activity is noteworthy. PGA showed one of the strongest observed correlations with SY (table 4, Figure 10a) and remained one of the most important explanatory variables after controlling for other factors (table 5, figure 11). As discussed in the introduction, a growing number of studies shows that seismicity can have a hitherto often neglected control on SY (e.g. Dadson et al., 2003; Cox et al., 2010; Hovius et al., 2011; Portenga and Bierman, 2011; Vanmaercke et al., 2014). Nonetheless, 
Africa is one of the most stable continents in terms of seismic activity (e.g. Shedlock et al., 2000), while the variability in other factors (e.g. topography, climate, land use) is very large. The fact that regional differences in seismicity have such a clear impact on observed SY can therefore be considered surprising.

Seismic impacts on SY are often attributed to earthquake-triggered landslides (e.g. Dadson et al., 2004; Hovius et al., 2011; Vanmaercke et al., 2014b). However, co-seismic landsliding mostly occurs only for earthquakes with a magnitude $\geq 4.3$ (Malamud et al., 2004). Since high-magnitude earthquakes are relatively rare in Africa (ANSS, 2013), other explanations, such as the seismic weakening of rocks due to fracturing (e.g. Molnar et al., 2007; Koons et al., 2012) or an increased rate of river incision as a response to catchment uplift (e.g. Whittaker et al., 2010) are perhaps of greater importance. Overall, the linkages between seismicity and SY as well as the underlying erosion processes remain poorly understood. This is also illustrated by Cox et al. (2010) who noted that, due to unknown reasons, the spatial distribution of Lavakas (i.e. large gullies) on Madagascar mainly correlates with the occurrence of low-magnitude earthquakes.

\subsection{Simulating spatial patterns of sediment yield in Africa}

\subsubsection{An African sediment yield model}

Building on the results of our statistical analyses (see section 4.2), a multiple regression model was constructed that simulates spatial variation in SY. The selection of variables and the type of relationship (exponential or power law) was based on the results of the normal and partial correlation analyses (table 4 and 5), the individual regression analyses (figure 10) and the stepwise regression analyses (figure 11), showing that variability in SY is mainly controlled by seismicity, topography, vegetation cover and runoff $\left(n=507, R^{2}=0.40\right)$ :

$$
S Y_{\text {Pred }}=1.49 \times \mathrm{e} \mathrm{e}^{1.24 \text { PGA }} \times \mathrm{MLR}^{0.66} \mathrm{x} \mathrm{e}^{-0.05 \text { TreeCover }} \times \mathrm{Ro}^{0.24}
$$

With $\mathrm{SY}_{\text {Pred }}$ the predicted sediment yield in $\mathrm{t} \mathrm{km}^{-2} \mathrm{y}^{-1}$, PGA the average expected Peak Ground Acceleration with an exceedance probability of $10 \%$ in 50 years, MLR the average height difference within a radius of $5 \mathrm{~km}$, TreeCover the estimated percentage of the catchment covered by trees and Ro the estimated average annual runoff depth (see table 3 ).

The model explains $40 \%$ of the observed variability of $\ln (\mathrm{SY})$ (figure 12 ). $74 \%$ of the predicted values deviate less than a factor five from their corresponding observed SY, while $88 \%$ deviate less than a factor ten. Hence, the unexplained variance remains relatively large. Apart from the parameters included in Eq.1, several other variables showed a significant partial correlation with SY (table 5). However, adding these to the model lead to only very 
small increases in explained variance. Moreover, 'Method' is the most frequently selected variable in stepwise regressions after runoff depth (figure 11). This indicates that the type of SY measurement (derived from gauging station measurements or reservoir sedimentation rates) is more important for explaining variation in SY than catchment size, lithology, air temperature, climatic variability or other considered factors. Including these other significant variables would therefore involve the risk of overfitting the model. Also 'Method' was not included in the model since it does not reflect a catchment characteristic and added little to the explained variance (figure 12).

\subsubsection{Unexplained variance}

The relatively low fraction of variance explained by our model (Eq. 1; $\mathrm{R}^{2}=0.40$ ) can be attributed to several reasons. Firstly, the observed SY data used are characterized by important uncertainties. A large fraction of the collected SY data has a poor or unknown quality, leading to potentially large deviations between the observed and true SY value (section 2.3; figure 4). We tested if only using SY observations of 'good' or 'acceptable' quality resulted in better results. However, this would strongly compromise the representativeness of our model, since these data are mainly clustered in northern and southern Africa and very scarcely available for other parts of Africa (figure 8).

Secondly, also the variables included in the model (Eq. 1) involve important uncertainties. Although MLR provides a robust proxy of topographic steepness on global or continental scales (e.g. Montgomery and Brandon, 2002), more refined measures based on more detailed DEMs may increase the explained variance (e.g. de Vente et al., 2009). Likewise, the fractions of tree cover in each catchment are only coarse-scale estimates based on satellite imagery obtained between 1992 and 1993 (Defries et al., 2000). These estimates may deviate significantly from the actual vegetation cover in the catchment during the SY measuring period. Also the PGA-values are subject to important uncertainties, associated with the earthquake inventories and extrapolation methods they are based on (Grünthal et al., 1999; Shedlock et al., 2000). Furthermore, the Ro-values used are only crude estimates of the longterm average runoff depth (table 3; Fekete et al., 1999). Replacing these estimates by runoff measurements corresponding to the SY measuring period would most likely increase the explained variance. However, such observations were mostly unavailable.

Thirdly, also factors that are not considered by our model most likely influence SY. As discussed in section 4.2.2, the lack of clear correlations between SY and catchment area, upstream reservoirs, lithology, temporal variations in climate or other factors may be 
attributed to the fact that they are only of limited importance compared to other factors, but also to the errors on the parameters used to quantify these effects. More accurate measures to express these factors may better explain some of the observed variability in SY.

These issues of uncertainty relate to a more fundamental problem that affects all empirical models aiming to predict SY or erosion rates. Namely, that spatially and/or temporary lumped parameters are often inadequate to describe the complex nature of erosion and sediment transport processes that not only depend on specific factors but also on their spatial patterns, their temporal changes and their interactions (e.g. Walling, 1983; Govers, 2011; Pelletier, 2012; de Vente et al., 2013). It can therefore be expected that more advanced models that take this spatial and temporal variability and interactions into account would result in higher prediction accuracies. However, this will only be true to some extent. Model errors are determined by a trade-off between errors in model concepts (i.e. simplifications of the actual situation) and errors in the input data used (de Vente et al., 2008; Govers, 2011; de Vente et al. 2013). Furthermore, the true unexplained variance of a model not only depends on model errors but also on errors on the observed SY values (Li, 1991; Van Rompaey et al., 2001). This is also indicated by the fact that more complex, spatially distributed and process-oriented models do not necessarily perform better in predicting SY than empirical models based on spatially and temporally aggregated parameters (e.g. de Vente et al., 2008; Govers, 2011; de Vente et al., 2013).

It should also be noted that the relatively low predictive power of our model $\left(\mathrm{R}^{2}=0.40\right.$; Figure 12) is certainly not exceptional for a SY model (e.g. Merrit et al., 2003; de Vente and Poesen, 2005; Balthazar et al., 2012; de Vente et al., 2013). Since our model was based on very similar model concepts and input data as used in other empirical SY models, its somewhat lower model performance is most likely mainly due to the large uncertainties on many of the SY observations (section 2.3).

\subsubsection{Spatial patterns of sediment yield in Africa}

Various studies have presented maps of expected SY values in Africa (e.g. Fournier, 1960; Strakhov, 1967; Walling and Webb, 1983; Walling, 1984; Pelletier, 2012). As discussed in the introduction and already pointed out by Walling (1984), many of these maps rely on very few SY observations and/or were often based on expert judgement without a thorough analysis of the factors controlling SY.

Despite its uncertainties, our model allows for a better insight into the spatial patterns of SY in Africa. Eq. 1 was applied to the gridded datasets of PGA, MLR, TreeCover and Ro and 
aggregated the result to a $50 \times 50 \mathrm{~km}^{2}$ resolution (roughly corresponding to the resolution Ro, i.e. the coarsest data layer; table 3). A comparison of the resulting simulated SY map with all available SY measurements indicates very similar patterns (figure 13).

Based on seismicity, topography, land cover and runoff (see section 4.3.1) our model predicts relatively high SY values along the Rift Valley and Madagascar, while central and Southwestern Africa and the Sahara are generally characterized by low SY values. The highest predicted SY values occur in the Atlas mountains and the northern part of the East African Rift Valley. This corresponds well with the observed SY values (figure 13).

While the average of all available SY observations for Africa equals $634 \mathrm{t} \mathrm{km}^{-2} \mathrm{y}^{-1}$ (section 3), the average simulated SY for the entire African continent is only $42 \mathrm{t} \mathrm{km}^{-2} \mathrm{y}^{-1}$ (figure 13). The latter value closely corresponds to the estimated area-specific sediment flux of African rivers to the oceans before the impact of large dams $\left(43 \pm 8.3 \mathrm{t} \mathrm{km}^{-2} \mathrm{y}^{-1}\right.$; Syvitski et al., 2005) and further indicates that our model (Eq. 1) provides realistic estimates of the overall magnitude and spatial variability of SY in Africa (figure 13). The large difference between the average observed SY and the average expected SY of the African continent indicates that SY observations in Africa are biased towards erosion-prone conditions and areas. This is also evident from figure 9, showing that regions with high MLR, high PGA, significant Ro and low TreeCover values are somewhat overrepresented, compared to the rest of Africa. Nonetheless, most of these over-represented regions with high SY-values are also characterized by high population densities and face important population increases during the next decades (e.g. North-western Africa, the Ethiopian highlands, the Lake Victoria region; UN-ESA, 2011). Therefore, the overall low average SY-value for Africa certainly not implies that problems related to SY are unimportant in Africa.

\section{Conclusions}

Africa has been largely underrepresented in previous studies aiming to understand the factors controlling SY at regional and continental scales (e.g. table 1). By means of an extensive literature review on SY observations in Africa, we addressed this research gap. We compiled and georeferenced SY measurements for 682 African catchments (comprising more than 8340 catchment years of observations). With the exception of some countries, SY measurements are available for most of the populated regions of Africa (figure 1). Nonetheless, data availability remains relatively low compared to other continents (see section 2.2). Furthermore, SY observations derived from gauging stations measurements are often based on short $(<5$ years) measuring periods and subjected to important uncertainties (figure 2 and 
4). SY values derived from reservoir sedimentation rates are generally more reliable, but unavailable for large parts of Africa (figure 1).

The available SY observations display clear regional patterns: the Atlas mountains and the Rift region are generally characterized by relatively high SY values, while rivers in western and central Africa have generally lower SY values (figures 7). Extensive (partial) correlation analyses showed that these spatial patterns are best explained by differences in seismic activity, topography, vegetation cover and runoff. Combining these four factors resulted in a model that explains about $40 \%$ of the observed variation in SY (Eq. 1; figure 12). The large fraction of unexplained variance is probably attributable to the large uncertainties on many of the SY measurements, errors on the used predictive variables and the fact that other potentially relevant factors are not considered by our model. Nonetheless, this model was capable to simulate the spatial patterns of observed SY in Africa fairly well (figure 13).

These results have important implications. During the coming decades, Africa faces large population increases and important climatic changes. The fact that differences in SY at the continental scale are significantly correlated to tree cover and runoff indicates that that these changes and their impact on land cover may have significant impacts on the sediment load of African rivers. Since high sediment loads form a potential threat to many existing or planned reservoirs, such changes may also threaten the future water availability in Africa. Likewise, they may affect the ecology of various aquatic systems in Africa.

Also the fact that seismicity explains a significant part of the observed variation in SY is important. A growing number of studies shows that seismic activity can have important but hitherto often neglected impacts on contemporary erosion rates and SY. Nonetheless, most of these studies focus on regions that are seismically very active or on regions with strongly contrasting degrees of seismic activity. In Africa, however, both the differences and overall degree of seismicity are limited. It is therefore noteworthy that seismic activity still has such a clear impact on the spatial variation of SY in Africa, despite the large variability in climate, land cover and other factors. The mechanisms explaining this impact are currently poorly understood, but may be related to the seismic weakening of surface lithologies, tectonically induced changes in river base levels or (to a limited extent) earthquake-triggered landsliding. Nevertheless, this result indicates that seismic activity should not be neglected in studies focussing on SY at regional scales.

Further research is needed to quantify and understand the processes through which tectonic activity affects SY. Likewise, more detailed analyses that take into account the effects of lithology, soil characteristics, upstream reservoirs, weather conditions and land use in a 
spatially (and temporally) explicit way may contribute to the development of more accurate SY models. Such models will be an important tool for addressing the hydrological challenges which Africa is facing. The dataset collected in the framework of this study may be an important aid in developing such models.

\section{Acknowledgments}

M. Vanmaercke received a postdoctoral grant from the Research Foundation Flanders (FWO). Financial support by several sponsors (KU Leuven, VLIR-IUC, FWO) for fieldwork campaigns conducted by the authors in various parts of Africa is acknowledged. The authors wish to thank all researchers who provided references or information on the sediment yield observations included in this study. We thank John Milliman and Sampurno Bruijnzeel for their helpful and constructive comments on this work.

\section{References}

Aalto, R., Dunne, T., Guyot, J., 2006. Geomorphic controls on Andean denudation rates. The Journal of Geology 114, 85-99.

Abdellaoui, B., Merzouk, A., Aberkan, M., Albergel, J., 2002. Bilan hydrologique et envasement du barrage Saboun (Maroc). Revue des sciences de l'eau/Journal of Water Science 15, 737-748.

Achite, M., Ouillon, S., 2007. Suspended sediment transport in a semiarid watershed, Wadi Abd, Algeria, 1973-1995. Journal of Hydrology 343, 187-202.

Ackerman, K.V., Mixon, D.M., Sundquist E.T., Stallard, R.F., Schwarz, G.E., Stewart, D.W., 2009. RESIS-II: An updated version of the original reservoir sedimentation survey information system (RESIS) satabase. United Staties Geological Survey Data Series 434, 26p.

Adwubi, A., Amegashie, B.K., Agyare, W.A., Tamene, L., Odai, S.N., Quansah, C., Vlek, P., 2009. Assessing sediment inputs to small reservoirs in Upper East region, Ghana. Lakes \& Reservoirs: Research \& Management 14, 279-287.

Akrasi, S.A, 2005. The assessment of suspended sediment inputs to Volta Lake. Lakes \& Reservoirs: Research \& Management 10, 179-186.

Akrasi, S.A., Ansa-Asare, O.D., 2008. Assessing sediment and nutrient transport in the Pra basin of Ghana. West African Journal of Applied Ecology 13, 45-54.

Alexandrov, Y., Laronne, J., Reid, I., 2007. Intra-event and inter-seasonal behaviour of suspended sediment in flash floods of the semi-arid northern Negev, Israel. Geomorphology 85, 85-97.

Alhassan, H.S., 2009. Viewpoint - Butterflies vs. hydropower: reflections on large dams in contemporary Africa. Water Alternatives 2, 148-160.

Amegashie, B.K., Quansah, C., Agyare, W.A., Tamene, L., Vlek, P.L., 2011. Sediment-bound nutrient export from five small reservoir catchments and its implications for the Sudan savanna zone of Ghana. Lakes \& Reservoirs: Research \& Management 16, 61-76.

Amogu, O., 2009. La dégradation des espaces sahéliens et ses conséquences sur l'alluvionnement du fleuve Niger moyen. PhD. Thesis, Université Joseph-FourierGrenoble I, France, 444 pp. 
Amphlett, M.B., 1984. Measurement of soil loss from experimental basins in Malawi. In: Walling, D.E., Foster, S.S.D., Wurzel, P. (Eds.), Harare Symposium, Challenges in African Hydrology and Water Resources. IAHS Publication no. 144, pp. 351-362.

ANSS, 2013. Advanced national seismic system - worldwide earthquake catalogue. Available at: http://www.ncedc.org/anss/catalog-search.html (accessed 20 July 2013).

Baade, J., Franz, S., Reichel, A., 2012. Reservoir siltation and sediment yield in the Kruger National Park, South Africa: a first assessment. Land Degradation \& Development 23, 586-600.

Balthazar, V., Vanacker, V., Girma, A., Poesen, J., Golla, S., 2012. Human impact on sediment fluxes within the Blue Nile and Atbara River basins. Geomorphology 180181: 231-241.

Barnes, R.F.W., 1990. Deforestation trends in tropical Africa. African Journal of Ecology 28, 161-173.

Bartle, A., 2002. Hydropower potential and development activities. Energy Policy 30, 12311239.

BCEOM, 1997. Abbay River Basin Integrated Development Master Plan Project. Phase 2: Data collection - site investigation survey and analysis, Section II: Sectoral studies, Volume II: Water Resources - Hydrology, 6-83.

Bengueddach, B., Chabouni, I., 1997. Envasement et devasement des retenues en Algerie. Transactions of the International Congress of Large Dams 3, 1200-1210.

Bednarczyk, T., Madeyski, M., 1996. Erosional processes in small Carpathian watersheds. In: Walling D.E., Webb B. (Eds.), Erosion and Sediment Yield: Global and Regional Perspectives (Proceedings of the Exeter Symposium, July 1996) IAHS Publication no. 236, IAHS, Wallingford, United Kingdom, pp. 399-404.

Billi, P., el Badri Ali, O., 2010. Sediment transport of the Blue Nile at Khartoum. Quaternary International 226, 12-22.

Bolton, P., 1984. Sediment deposition in major reservoirs in the Zambezi Basin. In: Walling, D.E., Foster, S.S.D., Wurzel, P. (Eds.), Harare Symposium, Challenges in African Hydrology and Water Resources. IAHS Publication no. 144, pp. 559-567.

Bombi, K., Mwenyemali, K., Olivier, D., 2000. Etude Hydrologique du Bassin Nord-Ouest Du Lac Tanganyika. UNDP/GEF and UNOPS : Pollution control and other measures to Protect Biodiversity in Lake Tanganyika (RAF/92/G32), Report 10, 44 p.

Bossa, A.Y., Diekkrüger, B., Igué, A.M., Gaiser, T., 2012. Analyzing the effects of different soil databases on modeling of hydrological processes and sediment yield in Benin (West Africa). Geoderma 173-174, 61-74.

Boufaroua, M., Lamachère, J.M., Débabria, A., Ksibi, F., 2006. Prédétermination de l'envasement des lacs collinaires de la Dorsale tunisienne. Proceedings of the 14th ISCO conference of the International Soil Conservation Organization: Water management and soil conservation in semi-arid environments. ISCO, Marrakech, Morocco. 13 pp.

Bouraoui, F., Benabdallah, S., Jrad, A., Bidoglio, G., 2005. Application of the SWAT model on the Medjerda river basin (Tunisia). Physics and Chemistry of the Earth 30, 497507.

Brown, C.B., 1943. Discussion of sedimentation in reservoirs. In: Witzig, J. (Ed.). Proceedings of the American Society of Civil Engineers 69: 1493-1500.

Brown, T., Schneider, H., Harper, D., 1996. Multi-scale estimates of erosion and sediment yields in the Upper Tana basin, Kenya. In: Walling D.E., Webb B. (Eds.), Erosion and Sediment Yield: Global and Regional Perspectives (Proceedings of the Exeter Symposium, July 1996) IAHS Publication no. 236, IAHS, Wallingford, United Kingdom, pp. 49-54. 
Bruijnzeel, L.A., 2004. Hydrological functions of tropical forests: not seeing the soil for the trees? Agriculture, Ecosystems and Environment 104, 185-228.

Carré, P., 1972. Quelques aspects du régime des apports fluviatiles de matériaux solides en suspension vers le lac Tchad. Cah. O.R.S.T.O.M. sér. Hydrol. 9, 19-45.

CGIAR, 2008. SRTM 90m Digital elevation data. Available at: http: //srtm.csi.cgiar.org/ (accessed 19 July 2013).

Cox, R., Zentner, D., Rakotondrazafy, A., Rasoazanamparany, C., 2010. Shakedown in Madagascar: occurence of lavakas (erosional gullies) associated with seismic activity. Geology 38, 179-182.

Coynel, A., Seyler, P., Etcheber, H., Meybeck, M., Orange, D., 2005. Spatial and seasonal dynamics of total suspended sediment and organic carbon species in the Congo River. Global biogeochemical cycles 19, GB4019.

Dadson, S.J., Hovius, N., Chen, H., Dade, W.B., Hsieh, M.-L., Willet, S.D., Hu, J.-C., Horng, M.-J., Chen, M.-C., Stark, C.P., Lague, D., Lin, J.-C., 2003. Links between erosion, runoff variability and seismicity in the Taiwan orogen. Nature 426, 648-651.

Dadson, S.J., Hovius, N., Chen, H., Dade, W., Lin, J., Hsu, M., Lin, C., Ming-Jame, H., Chen, T., Milliman, J., Stark, C., 2004. Earthquake-triggered increase in sediment delivery from an active mountain belt. Geology 32, 733-736.

de Araújo, J.C., Knight, D.W., 2005. A review of the measurement of sediment yield in different scales. Engenharia Civil 58: 257-265.

Dearing, J., Battarbee, R., Dikau, R., Larocque, I., Oldfield, F., 2006. Human-environment interactions: learning from the past. Regional Environmental Change 6, 1-16.

Dedkov, A.P., Mozzherin, V.I, 1984. Erosia i stok nanosov mi zemle (Erosion and sediment yield on the Earth). Izdatelstvo Kazanskogo Universiteta, Kazan, Russia, 264 pp.

DeFries, R.S., Hansen, M.C., Townshend, J.R.G., Janetos, A.C., Loveland, T.R., 2000. A new global 1-km dataset of percentage tree cover derived from remote sensing. Global Change Biology 6, 247-254.

Delmas, M., Cerdan, O., Cheviron, B., Mouchel, J.M., 2011. River basin sediment flux assessments. Hydrological processes 25, 1587-1596.

de Vente, J., Poesen, J., 2005. Predicting soil erosion and sediment yield at the basin scale: scale issues and semi-quantitative models. Earth-Science Reviews 71, 95-125.

de Vente, J., Poesen, J., Bazzoffi, P., Van Rompaey, A., Verstraeten, G., 2006. Predicting catchment sediment yield in Mediterranean environments: the importance of sediment sources and connectivity in Italian drainage basins. Earth Surface Processes and Landforms 31, 1017-1034.

de Vente, J., Poesen, J., Govers, G., Boix-Fayos, C., 2009. The implications of data selection for regional erosion and sediment yield modelling. Earth Surface Processes and Landforms 34, 1994-2007.

de Vente, J., Poesen, J., Verstraeten, G., 2005. The application of semi-quantitative methods and reservoir sedimentation rates for the prediction of basin sediment yield in Spain. Journal of Hydrology 305, 63-86.

de Vente, J., Poesen, J., Verstraeten, G., Govers, G., Vanmaercke, M., Van Rompaey, A., Arabkehdri, M., Boix-Fayos, C., 2013. Predicting soil erosion and sediment yield at regional scales: where do we stand? Earth-Science Reviews 127, 16-29.

de Vente, J., Poesen, J., Verstraeten, G., Van Rompaey, A., Govers, G., 2008. Spatially distributed modelling of soil erosion and sediment yield at regional scales in Spain. Global and Planetary Change 60, 393-415.

de Vente, J., Verduyn, R., Verstraeten, G., Vanmaercke, M., Poesen, J., 2011. Factors controlling sediment yield at the catchment scale in NW Mediterranean geoecosystems. Journal of Soils and Sediments 11, 690-707. 
de Wit, M., Stankiewicz, J., 2006. Changes in surface water supply across Africa with predicted climate change. Science 311, 1917-1921.

Draper, N.R., Smith, H., 1998. Applied regression analysis. Wiley-Interscience, Hoboken, pp. 307-312.

Droux, J.P., Mietton, M., Olivry, J.C., 2003. Flux de matières particulaires en suspension en zone de savane soudanienne: l'exemple de trois bassins versants maliens représentatifs/Suspended sediment yields in the Sudanian savanna zone: Examples from three representative catchments in Mali. Géomorphologie: Relief, Processus, Environnement 9, 99-110.

Dunne, T., 1979. Sediment yield and land use in tropical catchments. Journal of Hydrology 42, 281-300.

Dürr, H., Meybeck, M., Dürr, S., 2005. Lithologic composition of the Earth's continental surfaces derived from a new digital map emphasizing riverine material transfer. Global Biogeochemical Cycles 19, 22 pp. (doi: 10.1029/2005GB002515).

EDIT-CSIC, 2007. Normalized Difference Vegetation Index (NDVI) data. Available at: http://edit.csic.es/Soil-Vegetation-LandCover.html (accessed 20 July 2013).

ERSDAC, 2009. ASTER GDEM. Available at: http://gdem.ersdac.jspacesystems.or.jp (accessed 19 July 2013).

FAO, 2008. AQUASTAT Global river sediment yields database. Available at: http://www.fao.org/nr/water/aquastat/sediment/index.stm (accessed: 22 August 2013).

Fekete, B.M., Vörösmarty, C.J., Grabs, W., 1999. Global composite runoff fields on observed river discharge and simulated water balances. Koblenz, Federal Institute of Hydrology (BfG) - Global Runoff Data Centre (GRDC), Report 22.

Fisher, R.A., 1924. The distribution of the partial correlation coefficient. Metron 3, 329-332.

Foster, I.D., Rowntree, K.M., Boardman, J., Mighall, T.M., 2012. Changing sediment yield and sediment dynamics in the Karoo Uplands, South Africa; Post-European impacts. Land Degradation \& Development 23, 508-522.

Fournier, F., 1960. Climat et Erosion. Presses Universitaires de France, Paris.

Fournier, F., 1969. Transports solides effectués par les cours d'eau. Bulletin of the International Association of Scientific Hydrology 14, 7-49.

Gallaire, R., 1986. Le Niger à Kandadji, synthèse des etudes. ORSTOM-TP-SOFRELEC, ORSTOM Niamey, Niger, $157 \mathrm{pp}$.

Goudie, A.S., Adams, W. and Orme, A.R., 1996. The physical geography of Africa, Oxford University Press, Oxford, England.

Ghenim, A., Seddini, A., Terfous, A., 2008. Variation temporelle de la dégradation spécifique du bassin versant de l'Oued Mouilah (nord-ouest Algérien)/Temporal variation of the specific sediment yield of the Wadi Mouilah basin (northwest Algeria). Hydrological Sciences Journal 53, 448-456.

Ghorbel, A., Claude, J., 1977. Mesure de l'envasement dans les retenues de sept barrages en Tunisie: estimation des transports solides. Proceedings of the Paris symposium on erosion and solid matter transport in inland waters, IAHS Publication No. 122, pp. 219-232.

Giardini, D., Grünthal, G., Shedlock, K., Zhang, P., 1999. The GSHAP global seismic hazard map. Annali di Geofisica 42, 1225-1230.

Govers, G., 2011. Misapplications and misconceptions of erosion models. In: Morgan, R.P.C., Nearing, M.A. (Eds.), Handbook of erosion modelling, 1st edition. Blackwell Publishing Ltd, Chichester, UK, pp. 117-134.

Grünthal, G., Bosse, C., Sellami, S., Mayer-Rosa, D., Giardini, D., 1999. Compilation of the GSHAP regional seismic hazard for Europe, Africa and the Middle East. Annali di Geofisica 42, 1215-1223. 
Guzman, C.D., Tilahun, S.A., Zegeye, A.D., Steenhuis, T.S., 2012. Suspended sediment concentration-discharge relationships in the (sub) humid Ethiopian highlands. Hydrology and Earth System Sciences Discussions 9, 9011-9041.

Hannah, D.M., Demuth, S., van Lanen, H.A., Looser, U., Prudhomme, C., Rees, G., Stahl, K., Tallaksen, L.M., 2011. Large-scale river flow archives: importance, current status and future needs. Hydrological Processes 25, 1191-1200.

Haregeweyn, N., Poesen, J., Nyssen, J., De Wit, J., Haile, M., Govers, G., Deckers, S., 2006. Reservoirs in Tigray (northern Ethiopia): characteristics and sediment deposition problems. Land Degradation and Development 17, 211-230.

Haregeweyn, N., Poesen, J., Nyssen, J., Govers, G., Verstraeten, G., de Vente, J., Deckers, J., Moeyersons, J., Haile, M., 2008. Sediment yield variability in Northern Ethiopia: a quantitative analysis of its controlling factors. Catena 75, 65-76.

Haregeweyn, N., Melesse, B., Tsunekawa, A., Tsubo, M., Meshesha, D., Balana, B.B., 2012. Reservoir sedimentation and its mitigating strategies: a case study of Angereb reservoir (NW Ethiopia). Journal of Soils and Sediments 12, 291-305.

Hecky, R.E., Bootsma, H.A., Kingdon, M.L., 2003. Impact of land use on sediment and nutrient yields to Lake Malawi/Nyasa (Africa). Journal of Great Lakes Research 29, 139-158.

Holeman, J.N., 1968. The sediment yield of major rivers of the world. Water Resources Research 4, 737-747.

Hooke, J.M., 2006. Human impacts on fluvial systems in the Mediterranean region. Geomorphology 79, 311-335.

Hovius, N., Meunier, P., Ching-Weei, L., Hongey, C., Yue-Gau, C., Dadson, S., Ming-Jame, H., Lines, M., 2011. Prolonged seismically induced erosion and the mass balance of a large earthquake. Earth and Planetary Science Letters 304, 347-355.

Hudson, P.F., 2003. Event sequence and sediment exhaustion in the lower Panuco Basin, Mexico. Catena 52, 57-76.

Jansen, J., Painter, R., 1974. Predicting sediment yield from climate and topography. Journal of Hydrology 21, 371-380.

Jansson, M.B., 1982. Land erosion by water in different climates. Uppsala universitet. Naturgeografiska institutionen, Almqvist och Wiksell International, Report 57, Stockholm, Sweden, $151 \mathrm{pp}$.

Jansson, M.B., 1988. A global survey of sediment yield. Geografiska Annaler 70A, 81-98.

Kabell, T.C., 1984. Sediment storage requirements for reservoirs. Harare Symposium, challenges in African hydrology and water resources. IAHS Publication no. 144, pp. 569-576.

Karekezi, S., Kithyoma, W., 2002. Renewable energy strategies for rural Africa: is a PV-led renewable energy strategy the right approach for providing modern energy to the rural poor of sub-Saharan Africa? Energy Policy 30, 1071-1086.

Khanchoul, K., Altschul, R., Assassi, F., 2009. Estimating suspended sediment yield, sedimentation controls and impacts in the Mellah Catchment of Northern Algeria. Arabian Journal of Geosciences 2, 257-271.

Kissi, E., Poesen, J., Diels, J., Broothaerts, N., Vanopstal, M., 2011. Spatial and temporal variability of sediment yield of Gilgel Gibe catchment, Southwestern Ethiopia. Proceedings of Water 2011 - Integrated water resources management in tropical and subtropical drylands (19-26 September 2011, Mekelle, Ethiopia), Book of Abstracts, p. 81.

Kithha, S.M., 1997. Land use changes and their effects on sediment transport and soil erosion within the Athi drainage basin, Kenya. In: Walling, D.E., Probst, J.-L. (Eds.), Human 
impact on erosion and sedimentation (Proceedings of the Rabat 1997 Symposium), IAHS Publication no. 245, IAHS, Wallingford, United Kingdom, pp. 145-150.

Koons, P., Upton, P., Barker, A., 2012. The influence of mechanical properties on the link between tectonic and topographic evolution. Geomorphology 137, 168-180.

Lane, L.J., Hernandez, M., Nichols, M., 1997. Processes controlling sediment yield from watersheds as functions of spatial scale. Environmental Modelling \& Software 12, 355-369.

Lahlou, A., 1996. Environmental and socio-economic impacts of erosion and sedimentation in North Africa. In: Walling D.E., Webb B. (Eds.), Erosion and sediment yield: global and regional perspectives (Proceedings of the Exeter Symposium, July 1996) IAHS Publication no. 236, IAHS, Wallingford, United Kingdom, pp. 491-500.

Laraque, A., Bricquet, J.P., Pandi, A., Olivry, J.C., 2009. A review of material transport by the Congo river and its tributaries. Hydrological Processes 23, 3216-3224.

Lehner, B., Verdin, K., Jarvis, A., 2006. Hydrological data and maps based on Shuttle elevation derivatives at multiple scales (HydroSHEDS) - Technical Documentation. World Wildlife Fund US, Washington, DC. 27p. Available at: http://hydrosheds.cr.usgs.gov (accessed 22 August 2013).

Lehner, B., Reidy Liermann, C., Revenga, C., Vorosmarty, C., Fekete, B., Crouzet, P., Doll, P., Endejan, M., Frenken, K., Magome, J., Nilsson, C., Robertson, J.C., Rodel, R., Sindorf, N., Wisser., D., 2011. Global reservoir and dam database, version 1 (GRanDv1.: reservoirs, revision 01. Palisades, NY: NASA Socioeconomic data and applications center (SEDAC). Available at: http://sedac.ciesin.columbia.edu/data/set/grand-v1-reservoirs-rev01 (Accessed 20 July 2013).

Lewis, W.M., 2000. Basis for the protection and management of tropical lakes. Lakes \& Reservoirs: Research \& Management 5, 35-48.

Li, Z., 1991. Effects of check points on the reliability of DTM accuracy estimates obtained from experimental tests. Photogrammetric Engineering and Remote Sensing 57, 13331340

Liebe, J., Van De Giesen, N., Andreini, M., 2005. Estimation of small reservoir storage capacities in a semi-arid environment: a case study in the Upper East region of Ghana. Physics and Chemistry of the Earth 30, 448-454.

Liénou, G., 2007. Impacts de la variabilité climatique sur les ressources en eau et les transports de matières en suspension de quelques bassins versants représentatifs au Cameroun. PhD. Thesis, Université de Yaoundé I, Yaoundé, Cameroon, 486 pp.

Liénou, G., Mahe, G., Olivry, J.C., Naah, E., Servat, E., Sigha-Nkamdjou, L., Sighomnou, D., Ndam Ngoupayou, J., Ekodeck, G.E., Paturel, J.E., 2005. Régimes des flux des matières solides en suspension au Cameroun: revue et synthèse à l'échelle des principaux écosystèmes; diversité climatique et actions anthropiques/Regimes of suspended sediment flux in Cameroon: review and synthesis for the main ecosystems; climatic diversity and anthropogenic activities. Hydrological sciences journal 50, 111123.

Liénou, G., Mahé, G., Paturel, J.E., Servat, E., Ekodeck, G.E., Tchoua, F., 2009. Climatic variability and transport of suspended matter in the Mayo-Tsanaga basin (ExtremeNorth Cameroon). Sécheresse 20, 139-144.

Lootens, M., Kishimbi, Y., 1986. Some aspects of water and sediment discharge in the upstream section of the Kafubu River (Shaba-Zaire). Geografiska Annaler Series A $68,383-392$.

Lootens, M., Lumbu, S., 1986. Suspended sediment production in a suburban tropical basin (Lubumbashi, Zaire). Hydrological Sciences Journal 31, 39-49. 
Malamud, B.D., Turcotte, D.L., Guzzetti, F., Reichenbach, P., 2004. Landslides, earthquakes, and erosion. Earth and Planetary Science Letters 229, 45-59.

Markus M., Demissie M., 2006. Predictability of annual sediment loads based on flood events. J. Hydraul. Eng. 11, 354-361.

Mathieu, P., 1971. Érosion et transport solide sur un bassin versant forestier tropical (Bassin de l'Amitioro, Côte d'Ivoire). Cah. ORSTOM, Sér. Géol. III, 31-59.

Mathworks, 2013. Documentation center : Stepwisefit. Available at : http://www.mathworks.nl/help/stats/stepwisefit.html (accessed 20 July 2013).

McCarthy, T.S., Metcalfe, J., 1990. Chemical sedimentation in the semi-arid environment of the Okavango delta, Botswana. Chemical geology 89, 157-178.

Merritt, W., Letcher, R., Jakeman, A., 2003. A review of erosion and sediment transport models. Environmental Modelling \& Software 18, 761-799.

Meshesha, D.T., Tsunekawa, A., Tsubo, M., Haregeweyn, N., 2011. Spatial analysis and semi-quantitative modeling of specific sediment yield in six catchments of the central rift valley of Ethiopia. Journal of Food, Agriculture \& Environment 9, 784-792.

Meybeck, M., 2003. Global analysis of river systems: from Earth system controls to Anthropocene controls. Phil. Trans. R. Soc. B 358, 1935-1955.

Meybeck, M., Ragu, A., 1995. River Discharges to the Oceans: an Assessment of Suspended Solids, Major Ions and Nutrients. U.N. Environment Programme (UNEP), Nairobi, Kenya, 240 pp.

Milliman, J.D., Syvitski, J.P., 1992. Geomorphic/tectonic control of sediment discharge to the ocean: the importance of small mountainous rivers. The Journal of Geology, 525-544.

Milliman, J.D., Rutkowski, C.M., Meybeck, M., 1995. River discharge to the sea: a global river index (GLORI). International Geosphere Biosphere Program (IBGP): LandOcean Interactions in the Coastal Zone (LOICZ), 138 pp.

Milliman, J.D., Farnsworth, K.L., 2011. River discharge to the coastal ocean: a global synthesis. Cambridge University Press, Cambridge, United Kingdom, 384 pp.

Moatar, F., Person, G., Meybeck, M., Coynel, A., Etcheber, H., Crouzet, P., 2006. The influence of contrasting suspended particulate matter transport regimes on the bias and precision of flux estimates. Science of the Total Environment 370, 515-531.

Moliere, D.R., Evans, K.G., Saynor, M.J., Erskine, W.D., 2004. Estimation of suspended sediment loads in a seasonal stream in the wet-dry tropics, northern Territory, Australia. Hydrological Processes 18, 531-544.

Molnar, P., Anderson, R.S., Anderson, S.P., 2007. Tectonics, fracturing of rock, and erosion. Journal of Geophysical Research 112, F03014, doi: 10.1029/2005JF000433.

Montgomery, D.R., Brandon, M.T., 2002. Topographic controls on erosion rates in tectonically active mountain ranges. Earth and Planetary Science Letters 201, 481-489.

Morehead, M.D., Syvitski, J., Hutton, E.W.H., Peckham, S.D., 2003. Modeling the temporal variability in the flux of sediment from ungauged river basins. Global and Planetary Change 39, 95-110.

Nadal-Romero, E., Martínez Murillo, J., Vanmaercke, M., Poesen, J., 2011. Scaledependency of sediment yield from badland areas in Mediterranean environments. Progress in Physical Geography 35, 297-332.

Ndam Ngoupayou, J.R., Kpoumie, A., Boeglin, J.L., Liénou, G., Nfocgo, A.K., Ekodeck, G.E., 2007. Transports solides et erosion mécanique dans un écosystème tropical d"Afrique: example du basin versant de la Sanaga au Sud-Cameroun. Proceedings of the JSIRAUF ( ${ }^{\text {res }}$ Journées Scientifiques Inter-Réseaux de l'AUF, 6-9 novembre 2007, Hanoi, Vietnam), 6 pp.

Ndomba, P.M., 2011. Developing sediment yield prediction equations for small catchments in Tanzania. In: Dongmei C. (Ed.), Advances in data, methods, models and their 
applications in geoscience, InTech, pp. 241-260. Available at: http://www.intechopen.com/books/advances-in-data-methods-models-and-theirapplications-in-geoscience (accessed: 22 August 2013).

New, M., Lister, D., Hulme, M., Makin, I., 2002. A high-resolution data set of surface climate over global land areas. Climate Research 21, 1-25.

Ning Ma, 2006. Mathematical modelling of water soil erosion and sediment yield in large catchments. MSc. Thesis, University of Stellenbosch, Stelllenbosch, South Africa, 188 pp.

Nkotagu, H., Mbwano, K., 2000. Hydrology of selected watersheds along the Lake Tanganyika shoreline. UNDP/GEF and UNOPS: Pollution control and other measures to Protect Biodiversity in Lake Tanganyika (RAF/92/G32), Report 11, $111 \mathrm{pp}$.

Nouvelot, J.F., 1969. Mesure et étude des transport solides en suspension au Cameroun. Cahier O.R.S.T.O.M. série Hydrol. 6, 43-85.

Nyssen, J., Poesen, J., Moeyersons, J., Deckers, J., Haile, M., Lang, A., 2004. Human impact on the environment in the Ethiopian and Eritrean highlands - a state of the art. EarthScience Reviews 64, 273-320.

Nyssen, J., Clymans, W., Poesen, J., Vandecasteele, I., De Baets, S., Haregeweyn, N., Naudts, J., Hadera, A., Moeyersons, J., Haile, M., Deckers, J., 2009. How soil conservation affects the catchment sediment budget-a comprehensive study in the north Ethiopian highlands. Earth Surface Processes and Landforms 34, 1216-1233.

Odada, E.O., Olago, D.O., Kulindwa, K., Ntiba, M., Wandiga, S., 2004. Mitigation of environmental problems in Lake Victoria, East Africa: causal chain and policy options analyses. Ambio 33, 13-23.

Odada, E.O., Washington, O.O., Olago, D.O., 2009. Drivers of ecosystem change and their impacts on human well-being in Lake Victoria basin. African Journal of Ecology 47, 46-54.

Ogutu-Ohwayo, R., Hecky, R.E., Cohen, A.S., Kaufman, L., 1997. Human impacts on the African great lakes. Environmental Biology of Fishes 50, 117-131.

Olive, L.J., Rieger, W.A., 1992. Stream suspended sediment transport monitoring — why, how and what is being measured? In: Bogen, J., Walling, D.E., Day, T.J. (Eds.) Erosion and sediment transport monitoring programmes in river basins (Proceedings of the Oslo Symposium, August 1992), IAHS Publication no. 210, IAHS, Wallingford, United Kingdom, pp. 245-254.

Olivry, J.C., 1977. Transports solides en suspension au Cameroun. Proceedings of the Paris symposium on erosion and solid matter transport in inland waters, IAHS Publication No. 122, pp. 134-141.

Olivry, J.C., Lerique, J., Calvez, R., Gallaire, R., Hoorelbecke, R., Servat, E., Le Troquer, Y., Randon, R., 1989. Hydrologie de l'archipel du Cap-Vert: étude de l'île de Sao Nicolau. Editions de l'ORSTOM, institut français de recherche scientifique pour le développement en coopération, $384 \mathrm{pp}$.

Ongweny, G.S., 1978. Erosion and sediment transport in the Upper Tana catchment with special reference to the Thiba basin. PhD. Thesis, University of Nairobi, Nairobi, Kenya, 340 pp.

Ongwenyi, G.S., Kithiia, S.M., Denga, F.O., 1993. An overview of the soil erosion and sedimentation problems in Kenya. In: Hadley, R.F., Mizuyama, H.T. (Ed.), Sediment problems: strategies for monitoring, prediction and control (Proceedings of the Yokohama symposium, July 1993), IAHS Publication no. 217, IAHS, Wallingford, United Kingdom, pp. 217-224.

Parkin, G., Donnell, G.O., Ewen, J., Bathurst, J.C., O’Cennell, P.E., Lavabre, J., 1996. Validation of catchment models for predicting land-use and climate change impacts 2 : 
case study for a Mediterranean catchment. Journal of Hydrology 175, 595-613.

Pelletier, J.D., 2012. A spatially distributed model for the long - term suspended sediment discharge and delivery ratio of drainage basins. Journal of Geophysical Research, 117, F02028, doi:10.1029/2011JF002129.

Phillips, J., 2003. Alluvial storage and the long-term stability of sediment yields. Basin Research 15, 153-163.

Phillips, J., Webb, B., Walling, D.E., Leeks, G., 1999. Estimating the suspended sediment loads of rivers in the LOIS study area using infrequent samples. Hydrological processes 13, 1035-1050.

Picouet, C., 1999. Géodynamique d'un hydrosystème tropical peu anthropisé, le basin supérieur du Niger et son detla intérieur. PhD. Thesis, University of Montpellier, Montpellier, France, 386 pp.

Picouet, C., Hingray, B., Olivry, J.C., 2001. Empirical and conceptual modelling of the suspended sediment dynamics in a large tropical African river: the Upper Niger river basin. Journal of Hydrology 250, 19-39.

Portenga, E.W., Bierman, P.R., 2011. Understanding Earth's eroding surface with 10Be. GSA Today 21, doi: 10.1130/G111A.1.

Rapp, A., Axelsson, V., Berry, L., Murray-Rust, D.H., 1972. Soil erosion and sediment transport in the Morogoro river catchment, Tanzania. Geografiska Annaler A 54, 125155.

Reichenstein, M., Bahn, M., Ciais, P., Frank, D., Mahecha, M.D., Seneviratne, S.I., Zscheischler, J., Beer, C., Buchmann, N., Frank, D.C., Papale, D., Rammig, A., Smith, P., Thonicke, K., van der Velde, M., Vicca, S., Walz, A., Wattenbach, M., 2013. Climate extremes and the carbon cycle. Nature 500, 287-295.

Rockström, J., 2000. Water resources management in smallholder farms in Eastern and Southern Africa: an overview. Physics and Chemistry of the Earth B 25, 275-383.

Rooseboom, A., 1978. Sediment transport in Southern African rivers. Water S.A. 4, 14-17 (in Afrikaans).

Rooseboom, A., Verster, E., Zietsman, H.L., Lotriet, H.H., 1992. The development of the new sediment yield map of South Africa. Water Research Commision, Pretoria, South Africa, WRC Report No. 297/2/92.

Ryken, N., 2011. Assessment of spatial and temporal variability in stream flow and sediment yield in the upper Rwizi catchment, Southwest Uganda. MSc. Thesis, University of Leuven, Leuven, Belgium, $106 \mathrm{pp}$.

Ryken, N., Vanmaercke, M., Wanyama, J., Poesen, J., Deckers, S., Isabirye, M., 2013. The impact of papyrus wetland encroachment on the spatial and temperol variability in stream flow and sediment yield in the upper Rwizi catchment, Southwest Uganda. Proceedings of the day of young soil scientists (Brussels, 20 February 2013), book of abstract, p. 63.

Schmengler, A.C., 2011. Modeling soil erosion and reservoir sedimentation at hillslope and catchment scale in semi-arid Burkina Faso. PhD. Thesis, Rheinischen FriedrichWilhelms-Universität, Bonn, Germany, 244 pp.

Scott, D.F., Versfeld, D.B., Lesch, W., 1998. Erosion and sediment yield in relation to afforestation and fire in the mountains of the Western Cape Province, South Africa. South African Geographical Journal 80, 52-59.

SCRP, 2000a. Area of Anjeni, Gojam, Ethiopia: long-term monitoring of the agricultural environment 1984-1994. Soil erosion and conservation database, Soil Conservation Research Project, Berne, Switzerland, 1-89. 
SCRP, 2000b. Area of Gununo, Sidamo, Ethiopia: long-term monitoring of the agricultural environment 1981-1994. Soil erosion and conservation database, Soil Conservation Research Project, Berne, Switzerland, 1-69.

SCRP, 2000c. Area of Maybar, Wello, Ethiopia: long-term monitoring of the agricultural environment 1982-1994. Soil erosion and conservation database, Soil Conservation Research Project, Berne, Switzerland, 1-81.

SCRP, 2000d. Area of Dizi, Illubabor, Ethiopia: long-term monitoring of the agricultural environment 1988-1994. Soil erosion and conservation database, Soil Conservation Research Project, Berne, Switzerland, 1-69.

SCRP, 2000e. Area of Hunde Lafto, Harerge, Ethiopia: long-term monitoring of the agricultural environment 1982-1994. Soil erosion and conservation database, Soil Conservation Research Project, Berne, Switzerland, 1-79.

Selby, M.J., 1980. A rock mass strength classification for geomorphic purposes: with tests from Antarctica and New Zealand. Zeitschrift für Geomorphologie 24, 31-51.

Shahin, M, 1993. An overview of reservoir sedimentation in some African river basins. In: Hadley, R.F., Mizuyama, H.T. (Ed.), Sediment problems: strategies for monitoring, prediction and control (Proceedings of the Yokohama symposium, July 1993), IAHS Publication no. 217, IAHS, Wallingford, United Kingdom, pp. 93-100.

Shedlock, K., Giardini, D., Grünthal, G., Zhang, P., 2000. The GSHAP global seismic hazard map. Seismological Research Letters 71, 679-686.

Sichingabula, H.M., 2000. Analyses and results of discharge and sediment monitoring activities in the Southern Lake Tanganyika basin, Zambia - Annex report. UNDP/GEF Special study on sediment discharge and its consequences (SedSS), Technical Report Number 12, Dar es Salaam, Tanzania, 28 pp.

Smith, S.V., Renwick, W.H., Bartley, J.D., Buddemeier, R.W., 2002. Distribution and significance of small, artificial water bodies across the United States landscape. Science of the Total Environment 299, 21-36.

Steel, R.G.D., Torrie, J.H., 1960. Principles and procedures of statistics. McGraw-Hill, New York, $672 \mathrm{pp}$.

Stock, R., 2004. Africa South of the Sahara. A geographical interpretation. The Guilford Press, New York, 477 p.

Strakhov, N.M., 1967. Principles of lithogenesis, vol. 1. Oliver \& Boyd, Edinburgh.

Syvitski, J.P.M., Milliman, J., 2007. Geology, geography, and humans battle for dominance over the delivery of fluvial sediment to the coastal ocean. The Journal of Geology 115, $1-19$.

Syvitski, J.P.M., Vörösmarty, C.J., Kettner, A.J., Green, P., 2005. Impact of humans on the flux of terrestrial sediment to the global coastal ocean. Science 308, 376-380.

Tamene, L., Park, S.J., Dikau, R., Vlek, P.L.G., 2006. Analysis of factors determining sediment yield variability in the highlands of northern Ethiopia. Geomorphology 76, 76-91.

Tavares, J., 2010. Erosion des sols au Cap Vert: étude des processus et quantification à l' échelle de trois bassin versant de l'Île de Santiago. PhD. Thesis, CNR - Université de Bourgogne, Dijon, France, 227 pp.

Terfous, A., Megnounif, A., Bouanani, A., 2003. Détermination des dégradations spécifiques dans trois bassins versants des régions mediterraneennes algeriennes. In: Servat, E., Najem, W., Leduc, C., Shakeel, A. (Eds.), Hydrology of the Mediterranean and semiarid regions (Proceedings of an international symposium held at Montpellier, April 2003), IAHS Publication no. 278, IAHS, Wallingford, United Kingdom, pp. 366-372. 
Touaibia, B., 2010. Problématique de l'érosion et du transport solide en Algérie septentrionale. Sécheresse 21, 1-6.

Trimble, S.W., 1999. Decreased rates of alluvial sediment storage in the Coon Creek basin, Wisconsin, 1975-93. Science 285, 1244-1246.

UN-ESA, 2011. World population prospects - The 2010 revision: highlights and advance tables. United Nations, department of economic and social affairs, report ESA/P/WP.220.

UN-WATER, 2006. Kenya national water development report prepared for the 2nd UN world water development report 'Water: a shared responsibility', Report UNWATER/WWAP/2006/12.

USGS, 2008. Suspended-sediment database daily values of suspended sediment and ancillary data. Available at: http: //co.water.usgs.gov/sediment/ (accessed 07 July 2013).

Vanacker, V., Von Blanckenburg, F., Govers, G., Molina, A., Poesen, J., Deckers, J., Kubik, P., 2007. Restoring dense vegetation can slow mountain erosion to near natural benchmark levels. Geology 35, 303-306.

Van den wall Bake, G.W., 1986. Siltation and soil erosion survey in Zimbabwe. In: Hadley, R.F. (Ed.), Drainage basin sediment delivery (proceedings of a symposium held at Albuquerque, August 1986), IAHS Publication no. 159, IAHS, Wallingford, United Kingdom, pp. 69-80.

Vanmaercke, M., Zenebe, A., Poesen, J., Nyssen, J., Verstraeten, G., Deckers, J., 2010. Sediment dynamics and the role of flash floods in sediment export from medium-sized catchments: a case study from the semi-arid tropical highlands in northern Ethiopia, Journal of Soils and Sediments 10, 611-627.

Vanmaercke, M., Poesen, J., Verstraeten, G., Maetens, W., de Vente J, 2011a, Sediment yield as a desertification risk indicator. Science of the Total Environment 409, 1715-1725.

Vanmaercke, M., Poesen, J., Verstraeten, G., de Vente, J., Ocakoglu, F., 2011b, Sediment yield in Europe: spatial patterns and scale dependency. Geomorphology 130, 142-161.

Vanmaercke, M., Poesen, J., Radoane, M., Govers, G., Ocakoglu, F., Arabkhedri, M., 2012. How long should we measure? An exploration of factors controlling the inter-annual variation of catchment sediment yield. Journal of Soils and Sediments 12, 603-619.

Vanmaercke, M., Kettner, A.J., Van Den Eeckhaut, M., Poesen, J., Mamaliga, A., Verstraeten, G., Radoane, M., Obreja, F., Upton, P., Syvitski, J.M.P., Govers, G., 2014a, Moderate seismic activity affects contemporary sediment yields. Progress in Physical Geography 38, 145-172.

Vanmaercke, M., Obreja, F., Poesen, J., 2014b. Seismic controls on contemporary sediment export in the Siret river catchment, Romania. Geomorphology 216, 247-262.

Van Opstal, M. 2011. Sediment yield and sediment sources in the catchment of the Gilgel Gibe I dam, Southwestern Ethiopia. MSc. thesis, Department of earth and environmental sciences, KU Leuven.

Van Rompaey, A., Verstraeten, G., Van Oost, K., Govers, G., Poesen, J., 2001. Modelling mean annual sediment yield using a distributed approach. Earth Surface Processes Landforms 26, 1221-1236.

Verstraeten, G., Poesen, J., 2001. Factors controlling sediment yield from small intensively cultivated catchments in a temperate humid climate. Geomorphology 40, 123-144.

Verstraeten, G., Poesen, J., 2002. Using sediment deposits in small ponds to quantify sediment yield from small catchments: possibilities and limitations. Earth Surface Processes and Landforms 27, 1425-1439.

Vörösmarty, C.J., Fekete, B.M., Meybeck, M., Lammers, R.B., 2000. Global system of rivers: Its role in organizing continental land mass and defining land - to - ocean linkages. Global Biogeochemical Cycles 14, 599-621. 
Vörösmarty, C.J., 2002. Global water assessment and potential contributions from Earth systems science. Aquatic Science 64, 328-351.

Vörösmarty, C.J., Meybeck, M., Fekete, B., Sharma, K., Green, P., Syvitski, J., 2003. Anthropogenic sediment retention: major global impact from registered river impoundments. Global and Planetary Change 39, 169-190.

Vrieling, A., Sterk, G., de Jong, S.M., 2010. Satellite-based estimation of rainfall erosivity for Africa. Journal of Hydrology 395, 235-241.

Walling, D.E., 1983. The sediment delivery problem. Journal of Hydrology 65, 209-237.

Walling, D.E., 1984. The sediment yields of African rivers. In: Walling, D.E., Foster, S.S.D., Wurzel, P. (Eds.), Harare Symposium, Challenges in African Hydrology and Water Resources. IAHS Publication no. 144, pp. 265-283.

Walling, D.E., 1999. Linking land use, erosion and sediment yields in river basins. Hydrobiologia 410, 223-240.

Walling, D.E., 2006. Human impact on land-ocean sediment transfer by the world's rivers. Geomorphology 79, 192-216.

Walling, D.E., Kleo, A., 1979. Sediment yields of rivers in areas of low precipitation: a global view. In: Hydrology of areas of low precipitation (proceedings of a symposium held during the XVII assembly of the international union of geodesy and geophysics at Canberra, December 1979), IAHS Publication no. 128, pp. 479-493.

Walling, D.E., Webb, B.W., 1982. Sediment availability and the prediction of storm-period sediment yields. In: Walling, D.E. (Ed.), Recent developments in the explanation and prediction of erosion and sediment yield (proceedings of the Exeter symposium, 1982), IAHS Publication no. 137, IAHS Press, Wallingford, pp. 327-337.

Walling, D.E., Webb, B.W., 1983. Patterns of sediment yield. In: Gregory, K. (Ed.), Background to Paleohydrology, Wiley, New York, USA, pp. 69-100.

Walling, D.E., Collins, A.L., Sichingabula, H.M., Leeks, G.J.L., 2001. Integrated assessment of catchment suspended sediment budgets: a Zambian example. Land degradation \& development 12, 387-415.

Whittaker, A.C., Attal, M., Allen, P.A., 2010. Characterising the origin, nature and fate of sediment exported from catchments perturbed by active tectonics. Basin Research 22, 809-828.

Wisser, D., Frolking, S., Hagen, S., Bierkens, M.F.P., 2013. Beyond peak reservoir storage? A global estimate of declining water storage capacity in large reservoirs. Water Resources Research 49, 5732-5739.

Zenebe, A., Vanmaercke, M., Poesen, J., Verstraeten, G., Haregeweyn, N., Haile, M., Amare, K., Deckers, J., Nyssen, J., 2013. Spatial and temporal variability of river flows in the degraded semi-arid tropical mountains of northern Ethiopia. Zeitschrift für Geomorphologie 57, 143-169.

Zhang, Q., Justice, C.O., Jiang, M., Brunner, J., Wilkie, D.S., 2006. A GIS-based assessment on the vulnerability and future extent of the tropical forests of the Congo basin. Environmental Monitoring and Assessment 114, 107-121. 


\section{TABLES}

Table 1: Overview of global sediment yield (SY) inventories, their total number of catchments for which SY was observed, the number of SY observations in Africa, the relative share of SY observations that was measured in Africa and the range of catchment areas (A) for the included African SY observations. 'N.A.' means not available.

\begin{tabular}{ccccc}
\hline Reference & $\begin{array}{c}\text { Total \# SY- } \\
\text { observations }\end{array}$ & $\begin{array}{c}\text { \# African SY- } \\
\text { observations }\end{array}$ & $\begin{array}{c}\text { \% of observations } \\
\text { African }\end{array}$ & A-range Africa $\left(\mathrm{km}^{2}\right)$ \\
\hline Holeman (1968) & 110 & 5 & 4.5 & $2.1 \times 10^{4}-4.0 \times 10^{6}$ \\
Fournier (1969) & 139 & 0 & 0.0 & N.A. \\
Jansen and Painter (1974) & 79 & 3 & 3.8 & $1.1 \times 10^{6}-4.0 \times 10^{6}$ \\
Walling and Kleo (1979) & 1246 & 13 & 1.0 & N.A. \\
Dedkov \& Mozzherin (1984) & 3763 & 45 & 1.2 & $1.9 \times 10^{1}-3.7 \times 10^{6}$ \\
Jansson (1988) & 1358 & 117 & 8.6 & $>300^{\mathrm{a}}$ \\
de Araújo and Knight (2005) & 364 & 23 & 6.3 & $2.9 \times 10^{-1}-3.6 \times 10^{6}$ \\
Meybeck and Ragu (1995) & 219 & 24 & 11.0 & $9.0 \times 10^{3}-3.6 \times 10^{6}$ \\
Milliman et al. (1995) & 401 & 43 & 23.6 & $3.0 \times 10^{2}-3.8 \times 10^{6}$ \\
FAO (2008) & 869 & 205 & 8.5 & $1.9 \times 10^{1}-4.0 \times 10^{6}$ \\
Milliman and Farnsworth (2011) & 776 & 66 & $10.8 .8 \times 10^{6}$ \\
\hline
\end{tabular}

${ }^{\mathrm{a}} 300 \mathrm{~km}^{2}$ is the minimum A for the global dataset. The A-range for African catchments could not be retrieved 
Table 2: Overview of all collected Sediment Yield (SY) data. For each country, the number of catchments (\#), the corresponding number of catchment-years (catch. yr), the minimum and maximum catchment area (A) of the entries, the minimum and maximum reported SY values, and the sources of the data are indicated. For the number of catchments and catchment-years, a distinction is made between SY data derived from gauging station measurements (GS) or from reservoir sedimentation rates (R). 'N.A.' indicates that no data are available.

\begin{tabular}{|c|c|c|c|c|c|c|}
\hline Country & $\begin{array}{c}\text { \# GS } \\
\text { (catch. yr) }\end{array}$ & $\begin{array}{c}\text { \# R } \\
\text { (catch. yr) }\end{array}$ & $\begin{array}{c}\text { Total\# } \\
\text { (catch. yr) }\end{array}$ & $\min \mathrm{A}-\max \mathrm{A}\left(\mathrm{km}^{2}\right)$ & $\begin{array}{c}\min S Y-\max S Y \\
\left(t_{k k^{-2}}^{-1}\right)\end{array}$ & Sources \\
\hline Algeria & $45(307)$ & $32(836)$ & $77(1143)$ & $93-44,000$ & $63-7273$ & $\begin{array}{l}\text { Achite et al. (2007); Bengueddach and Chabouni (1997); FAO } \\
\text { (2008); Ghenim et al. (2008); Hooke (2006); Kanchoul et al. (2009); } \\
\text { Lahlou (1996); Milliman and Farns worth (2011); Terfous et al. } \\
\text { (2003); Touaibia (2010) }\end{array}$ \\
\hline Benin & $1(1)$ & N.A. & $1(1)$ & $50,000-50,000$ & $48-48$ & Milliman and Farns worth (2011) \\
\hline Botswana & $1(1)$ & N.A. & $1(1)$ & $530,000-530,000$ & $0.4-0.4$ & McCarthy and Metcalfe (1990) \\
\hline Burkina Faso & N.A. & $3(39)$ & $3(39)$ & $7.9-24$ & $30-441$ & Schmengler (2010) \\
\hline Cameroon & $20(60)$ & $1(1)$ & $21(61)$ & $0.58-130,000$ & $2.9-330$ & $\begin{array}{l}\text { Dedkov and Mozzherin (1984); Liénou et al. (2005); Liénou (2007); } \\
\text { Liénou et al. (2009); Milliman and Farns worth (2011); Ndam } \\
\text { Ngoupayou et al. (2007); Nouvelot (1969); Olivry (1977) }\end{array}$ \\
\hline Cape Verde & $5(30)$ & N.A. & $5(30)$ & $1.9-11$ & $10-4300$ & Olivry (1989); Tavares (2010) \\
\hline $\begin{array}{l}\text { Central African } \\
\text { Rep. }\end{array}$ & $7(14)$ & N.A. & $7(14)$ & $2590-553,900$ & $3.1-9.3$ & $\begin{array}{l}\text { Coynel et al. (2005); Laraque et al. (2009); Liénou et al. (2005); } \\
\text { Walling (1984) }\end{array}$ \\
\hline Chad & $10(31)$ & N.A. & $10(31)$ & $14,300-515,000$ & $1.2-65$ & Carré (1972); Dedkov and Mozzherin (1984); Liénou et al. (2005) \\
\hline Congo D.R. & $7(11)$ & N.A. & $7(11)$ & $8.5-3,800,000$ & $2.4-70.6$ & $\begin{array}{l}\text { Bombi et al. (2000); Laraque et al. (2009); Lootens and Kishimbi } \\
\text { (1986); Lootens and Lumbu (1986); Milliman and Farnsworth (2011) }\end{array}$ \\
\hline Congo Republic & $6(18)$ & N.A. & $6(18)$ & $13,500-3,500,000$ & $4.2-9.4$ & Laraque et al. (2009); Liénou et al. (2005) \\
\hline Egypt & N.A. & $1(1)$ & $1(1)$ & $2,960,000-2,960,000$ & $41-41$ & Shahin (1993) \\
\hline Eritrea & N.A. & $1(17)$ & $1(17)$ & $174-174$ & $2241-2241$ & Nyssen et al. (2004) \\
\hline Ethiopia & $58(323)$ & $20(124)$ & $78(447)$ & $0.72-172,254$ & $0.2-8387$ & $\begin{array}{l}\text { Balthazar et al. (2012); BCEOM (1997); FAO (2008); Guzman et al. } \\
\text { (2012); Haregeweyn et al. (2008); Haregeweyn et al. (2012); Kissi et } \\
\text { al. (2011); Meshesha et al. (2011); Nyssen et al. (2004); Nyssen et } \\
\text { al. (2009); SCRP (2000a); SCRP (2000b); SCRP (2000c); SCRP } \\
\text { (2000d); SCRP (2000e); Shahin (1993); Tamene et al. (2006); } \\
\text { Vanmaercke et al. (2010); Van Opstal (2011); Zenebe et al. (2013) }\end{array}$ \\
\hline Gambia & $1(1)$ & N.A. & $1(1)$ & $77,000-77,000$ & $2.6-2.6$ & Milliman and Farnsworth (2011) \\
\hline Ghana & $21(33)$ & $5(50)$ & $26(83)$ & $0.35-400,000$ & $9.1-15,699$ & $\begin{array}{l}\text { Adwubi et al. (2009); Akrasi (2005); Akrasi and Ansa-Asare (2008); } \\
\text { Amegashie et al. (2011); Milliman and Farns worth (2011) }\end{array}$ \\
\hline Guinea & $2(2)$ & N.A. & 2(2) & $9600-16,000$ & $21-24$ & Liénou et al. (2005); Milliman and Farnsworth (2011) \\
\hline Ivory Coast & $7(10)$ & N.A. & $7(10)$ & $0.02-97,000$ & $6.1-169$ & Mathieu (1971); Milliman and Farns worth (2011) \\
\hline Kenya & $20(161)$ & $4(26)$ & $24(187)$ & $24-42,000$ & $8.2-6330$ & $\begin{array}{l}\text { Brown et al. (1996); FAO (2008); Kithiia (1997); Milliman and } \\
\text { Farnsworth (2011); Ning Ma (2006); Ongweny (1978); Ongweny et } \\
\text { al. (1993); UN-WATER (2006) }\end{array}$ \\
\hline Lesotho & $16(98)$ & N.A. & $16(98)$ & $212-19,875$ & $3-2050$ & $\mathrm{FAO}(2008)$ \\
\hline Liberia & $1(1)$ & N.A. & $1(1)$ & $28,000-28,000$ & $189-189$ & Milliman and Farns worth (2011) \\
\hline Madagascar & $6(9)$ & N.A. & $6(9)$ & $575-59,000$ & $169-3130$ & FAO (2008); Milliman and Farns worth (2011) \\
\hline Malawi & $17(19)$ & N.A. & $17(19)$ & $0.05-12,110$ & $7.2-1605$ & Amphlett (1984); Hecky et al. (2003) \\
\hline Mali & $8(37)$ & N.A. & $8(37)$ & $17.5-141,000$ & $3.9-31$ & $\begin{array}{l}\text { Droux et al. (2003); Liénou et al. (2005); Picouet (1999); Picouet et } \\
\text { al. (2001) }\end{array}$ \\
\hline Morocco & $19(19)$ & $19(314)$ & $38(333)$ & $7.66-114,000$ & $100-4620$ & $\begin{array}{l}\text { Abdellaoui et al. (2002); FAO (2008); Hooke (2006); Jansson (1982); } \\
\text { Milliman and Farnsworth (2011); Walling (1984) }\end{array}$ \\
\hline Mozambique & $2(2)$ & $1(1)$ & $3(3)$ & $410,000-1,300,000$ & $37-135$ & Bolton (1984); Milliman and Farnsworth (2011) \\
\hline Niger & $10(29)$ & N.A. & $10(29)$ & $7500-757,640$ & $4.8-25$ & Amogu (2009); Gallaire (1986) \\
\hline Nigeria & $13(35)$ & N.A. & $13(35)$ & $2653-2,200,000$ & $7-344$ & $\begin{array}{l}\text { Dedkov and Mozzherin (1984); FAO (2008); Milliman and } \\
\text { Farns worth (2011) }\end{array}$ \\
\hline Senegal & $5(16)$ & N.A. & $5(16)$ & $7500-270,000$ & $2.1-11$ & Liénou et al. (2005); Milliman and Farnsworth (2011) \\
\hline South Africa & $38(333)$ & $136(4318)$ & $174(4651)$ & $0.18-1,000,000$ & $1-890$ & $\begin{array}{l}\text { Baade et al. (2012); Dedkov and Mozzherin (1984); FAO (2008); } \\
\text { Foster et al. (2012); Milliman and Farnsworth (2011); Rooseboom } \\
\text { (1978); Rooseboom et al. (1992); Scott et al. (1998) }\end{array}$ \\
\hline Sudan & $9(71)$ & $1(13)$ & $10(84)$ & $16,000-2,600,000$ & $38-3422$ & $\begin{array}{l}\text { Billi and el Badri Ali (2010); Dedkov and Mozzherin (1984); FAO } \\
\text { (2008); Nyssen et al. (2004) }\end{array}$ \\
\hline Tanzania & $6(24)$ & $11(221)$ & $17(245)$ & $1.2-180,000$ & $3.8-3132$ & $\begin{array}{l}\text { Dedkov and Mozzherin (1984); FAO (2008); Milliman and } \\
\text { Farnsworth (2011); Ndomba (2011); Nkotagu and Mbwano (2000); } \\
\text { Rapp et al. (1972); Sichingabula (2000) }\end{array}$ \\
\hline Togo & $1(1)$ & N.A. & $1(1)$ & $29,000-29,000$ & $55-55$ & Milliman and Farnsworth (2011) \\
\hline Tunesia & $2(2)$ & $41(286)$ & $43(288)$ & $0.85-22,000$ & $149-5070$ & $\begin{array}{l}\text { Boufaroua et al. (2006); Ghorbel and Claude (1977); Lahlou (1996); } \\
\text { Milliman and Farns worth (2011) }\end{array}$ \\
\hline Uganda & $8(8)$ & N.A. & $8(8)$ & $99-2121$ & $23-164$ & Ryken (2011); Ryken et al. (2013) \\
\hline Zambia & $4(6)$ & N.A. & $4(6)$ & $54-686$ & $1.2-21$ & Sichingabula (2000); Walling et al. (2001) \\
\hline Zimbabwe & $1(1)$ & $29(379)$ & $30(380)$ & $2.4-514,892$ & $10-704$ & $\begin{array}{l}\text { Bolton (1984); Dedkov and Mozzherin (1984); FAO (2008); Kabell } \\
\text { (1984); Van den wall Bake (1986) }\end{array}$ \\
\hline All data & 377 (1714) & 305 (6626) & $682(8340)$ & $0.02-3,800,000$ & $0.2-15,699$ & \\
\hline
\end{tabular}


Table 3: Catchment characteristics calculated for each catchment for which the catchment boundaries could be determined $(n=507)$. Resolution indicates the original spatial resolution of the data layer from which the parameter was derived. 'N.A.' indicates not applicable.

\begin{tabular}{|c|c|c|c|c|c|}
\hline Variable & Factor & Description & Derived from & Resolution & Units \\
\hline A & Size & Orignially reported catchment area. & $\begin{array}{l}\text { Original source of the SY- } \\
\text { data }\end{array}$ & N.A. & $\mathrm{km}^{2}$ \\
\hline $\mathrm{R}$ & Topography & Relief, i.e. the maximum altitude difference within the catchment. & ERSDAC (2009) & $30^{\prime \prime}$ x $30^{\prime \prime}$ & $\mathrm{m}$ \\
\hline MLR & Topography & $\begin{array}{l}\text { Mean Local Relief, where local relief is the maximum altitude } \\
\text { difference within a radius of } 5000 \mathrm{~m} \text {. }\end{array}$ & ERSDAC (2009) & $30 "$ x $30^{\prime \prime}$ & $\mathrm{m}$ \\
\hline Hstd & Topography & Standard deviation of the altitude within the catchment. & ERSDAC (2009) & $30 "$ x $30 "$ & $\mathrm{~m}$ \\
\hline $\mathrm{L}$ & Lithology & $\begin{array}{l}\text { Catchment lithology erodibility factor, defined by Syvitski and } \\
\text { Milliman (2007). Based on a global lithology map (Dürr et al., } \\
\text { 2005), a score was assigned to each lithology, depending on } \\
\text { their erodibility. Scores ranged between } 0.5 \text { for erosion-resistant } \\
\text { rock types (e.g. acidic plutonic or metamorphic rocks) and } 3 \text { for } \\
\text { very erodible lithologies (e.g. loess). }\end{array}$ & Dürr et al. (2005) & $30^{\prime} \times 30^{\prime}$ & N.A. \\
\hline PGA & Tectonics & $\begin{array}{l}\text { Peak Ground Acceleration with an exceedance probability of } \\
10 \% \text { in } 50 \text { years. }\end{array}$ & $\begin{array}{l}\text { Giardini et al. (1999); } \\
\text { Shedlock et al. (2000) }\end{array}$ & $6^{\prime} \times 6^{\prime}$ & $\mathrm{m} \mathrm{s}^{-2}$ \\
\hline $\mathrm{T}$ & Climate & Average (1961-1990) annual air temperature. & New et al. (2002) & $10^{\prime} \times 10^{\prime}$ & ${ }^{\circ} \mathrm{C}$ \\
\hline $\mathrm{P}$ & Climate & Average (1961-1990) annual rainfall. & New et al. (2002) & $10^{\prime} \times 10^{\prime}$ & $\mathrm{mm}$ \\
\hline VarP & Climate & $\begin{array}{l}\text { Relative monthly rainfall variability. VarP was calculated as the } \\
\text { difference between the wettest and driest month of the year, } \\
\text { divided by the mean monthly rainfall. Minimum, maximum and } \\
\text { mean monthly rainfall values, were derived from average rainfall } \\
\text { statistics for the period 1961-1990. }\end{array}$ & New et al. (2002) & $10^{\prime} \times 10^{\prime}$ & $\%$ \\
\hline $\mathrm{RE}$ & Climate & $\begin{array}{l}\text { Average Rainfall Erosivity. RE-values were based on the } \\
\text { Modified Fournier Index, calculated from monthly rainfall data } \\
\text { for the period 1998-2008 and data from literature. }\end{array}$ & Vrieling et al. (2010) & $15^{\prime} \times 15^{\prime}$ & $\begin{array}{l}\text { MJ mm ha- } \\
{ }^{1} h^{-1} y^{-1}\end{array}$ \\
\hline Ro & Climate & $\begin{array}{l}\text { Estimated annual runoff depth, based on observed river } \\
\text { discharges and simulated water balances. }\end{array}$ & Fekete et al. (1999) & $30^{\prime} \times 30^{\prime}$ & $\mathrm{mm} \mathrm{y}^{-1}$ \\
\hline VarRo & Climate & $\begin{array}{l}\text { Relative monthly runoff variability. VarRo was calculated as the } \\
\text { difference between the highest and lowest estimated monthly } \\
\text { runoff, divided by the average monthly runoff. }\end{array}$ & Fekete et al. (1999) & $30^{\prime} \times 30^{\prime}$ & $\%$ \\
\hline TreeCover & Land use & $\begin{array}{l}\text { Estimated percentage of the catchment that is covered by trees, } \\
\text { as derived from 1992-1993 satellite data. }\end{array}$ & Defries et al. (2000) & $30^{\prime \prime}$ x $30^{\prime \prime}$ & $\%$ \\
\hline VarNDVI & Land use & $\begin{array}{l}\text { Estimated intra-annual changes in vegetation cover, derived from } \\
\text { average monthly NDVI-values for the period } 1982-2000 \\
\text { (except 1994). VarNDVI was calculated as the difference } \\
\text { between the maximum and minimum monthly NDVI, divided by } \\
\text { the mean monthly NDVI value. }\end{array}$ & EDIT-CSIC (2007) & $6^{\prime} \times 6^{\prime}$ & $\%$ \\
\hline Reservoirs & $\begin{array}{l}\text { Reservoir } \\
\text { impacts }\end{array}$ & $\begin{array}{l}\text { Boolean variable indicating if the catchment is potentially affected } \\
\text { by large reservoirs (1) or not }(0) \text {. Values were calculated by } \\
\text { making an overlay between the catchment boundaries and the } \\
\text { locations of reservoirs included in the GranD reservoir database. }\end{array}$ & Lehner et al. (2011) & N.A. & N.A. \\
\hline Method & $\begin{array}{l}\text { Measuring } \\
\text { Procedure }\end{array}$ & $\begin{array}{l}\text { Dummy variable to indicate if the SY-value was derived from } \\
\text { measurements at gauging stations }(0) \text { or from bathymetric surveys } \\
\text { of a reservoir (1) }\end{array}$ & $\begin{array}{l}\text { Original source of the SY- } \\
\text { data }\end{array}$ & N.A. & N.A. \\
\hline
\end{tabular}


Table 4: Pearson correlation coefficients between all considered variables (table 3 ) and with catchment sediment yield (SY) for the 507 catchment selected for detailed analyses. Values in bold are highly significant $(\mathrm{p}<0.0001)$. Values in normal font are significant $(\mathrm{p}<0.05)$.

Correlations in italic are insignificant $(\mathrm{p}>0.05)$. ' $\mathrm{n}$ ' indicates that the variable was logarithmically transformed.

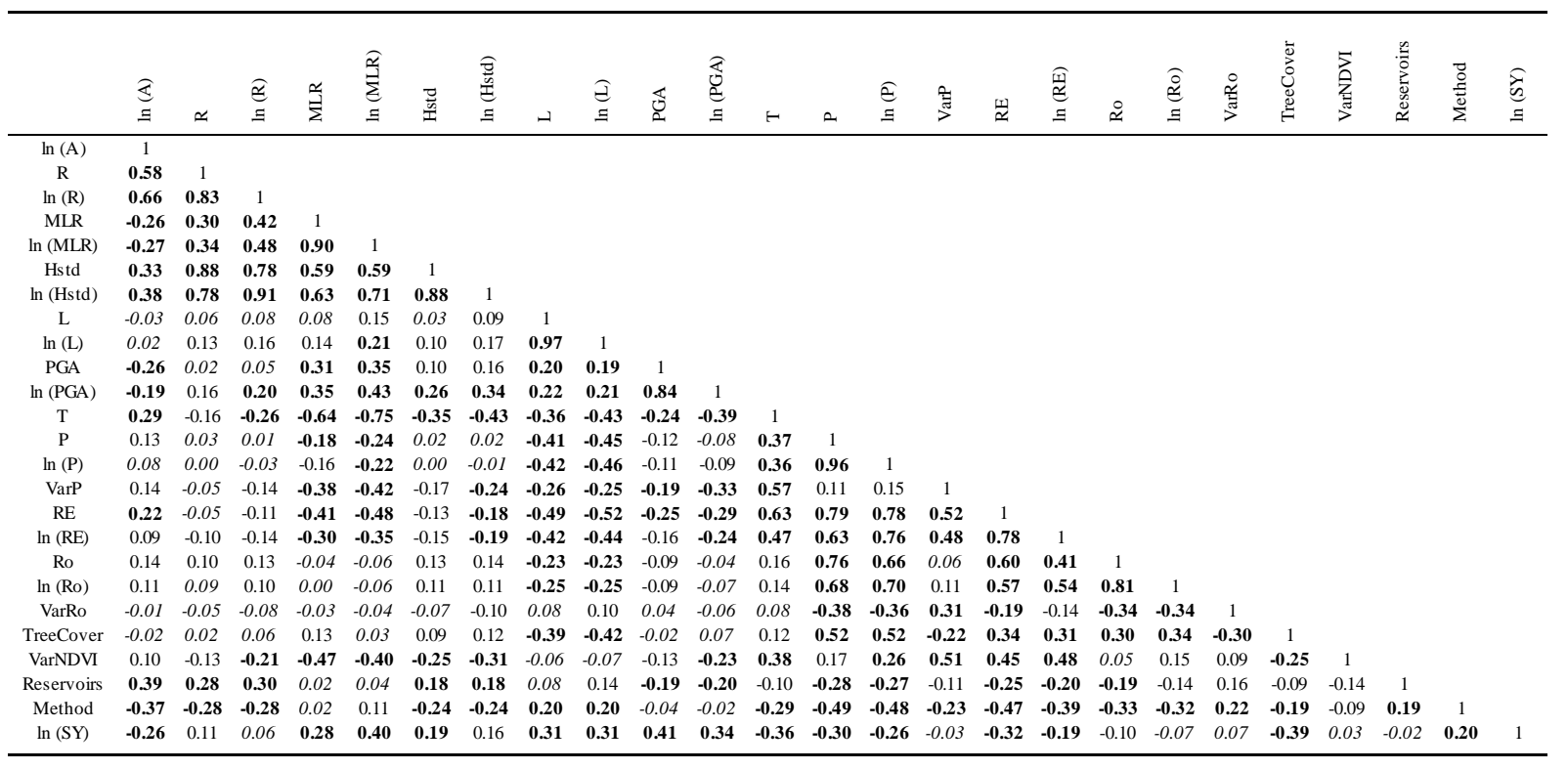


Table 5: Partial correlation coefficient (partial r) and corresponding p-value for each considered variable with $\ln (\mathrm{SY})$ (i.e. the natural logarithm of the catchment sediment yield). Each partial correlation was calculated by controlling for all variables that relate to different factors than the considered variable (see table 3). For example: the partial $r$ for PGA was calculated by controlling for all other variables except ' $\ln (\mathrm{PGA})$ '. Variables in bold show a very significant partial correlation $(\mathrm{p}<0.0001)$. Variables in normal font show a significant partial correlation $(\mathrm{p}<0.05)$. Variables in italic are insignificantly partially correlated $(\mathrm{p}>$ $0.05)$.

\begin{tabular}{|c|c|c|c|}
\hline Variable & Factor & partial $\mathrm{r}$ & $\mathrm{p}$-value \\
\hline PGA & Tectonics & 0.34 & $<0.0001$ \\
\hline $\ln$ (PGA) & Tectonics & 0.28 & $<0.0001$ \\
\hline Hstd & Topography & 0.28 & $<0.0001$ \\
\hline $\mathbf{R}$ & Topography & 0.27 & $<0.0001$ \\
\hline Tree Cover & Land use & -0.27 & $<0.0001$ \\
\hline $\ln (R)$ & Topography & 0.23 & $<0.0001$ \\
\hline $\ln ($ Hstd) & Topography & 0.23 & $<0.0001$ \\
\hline $\ln (\mathbf{M L R})$ & Topography & 0.22 & $<0.0001$ \\
\hline $\ln (\mathrm{Ro})$ & Climate & 0.19 & $<0.0001$ \\
\hline $\ln (\mathrm{RE})$ & Climate & 0.14 & 0.0017 \\
\hline Ro & Climate & 0.14 & 0.0026 \\
\hline MLR & Topography & 0.13 & 0.0029 \\
\hline $\mathrm{L}$ & Lithology & 0.12 & 0.0060 \\
\hline Method & Measuring Procedure & 0.12 & 0.0100 \\
\hline VarP & Climate & 0.11 & 0.0136 \\
\hline $\mathrm{RE}$ & Climate & 0.09 & 0.0467 \\
\hline $\ln L$ & Lithology & 0.09 & 0.0539 \\
\hline $\ln P$ & Climate & 0.08 & 0.0612 \\
\hline VarRo & Climate & -0.08 & 0.0672 \\
\hline VarNDVI & Land use & 0.08 & 0.0854 \\
\hline $\ln A$ & Size & -0.07 & 0.1291 \\
\hline$P$ & Climate & 0.04 & 0.3751 \\
\hline Reservoirs & Reservoir impacts & 0.03 & 0.5257 \\
\hline$T$ & Climate & -0.02 & 0.5957 \\
\hline
\end{tabular}




\section{FIGURES}

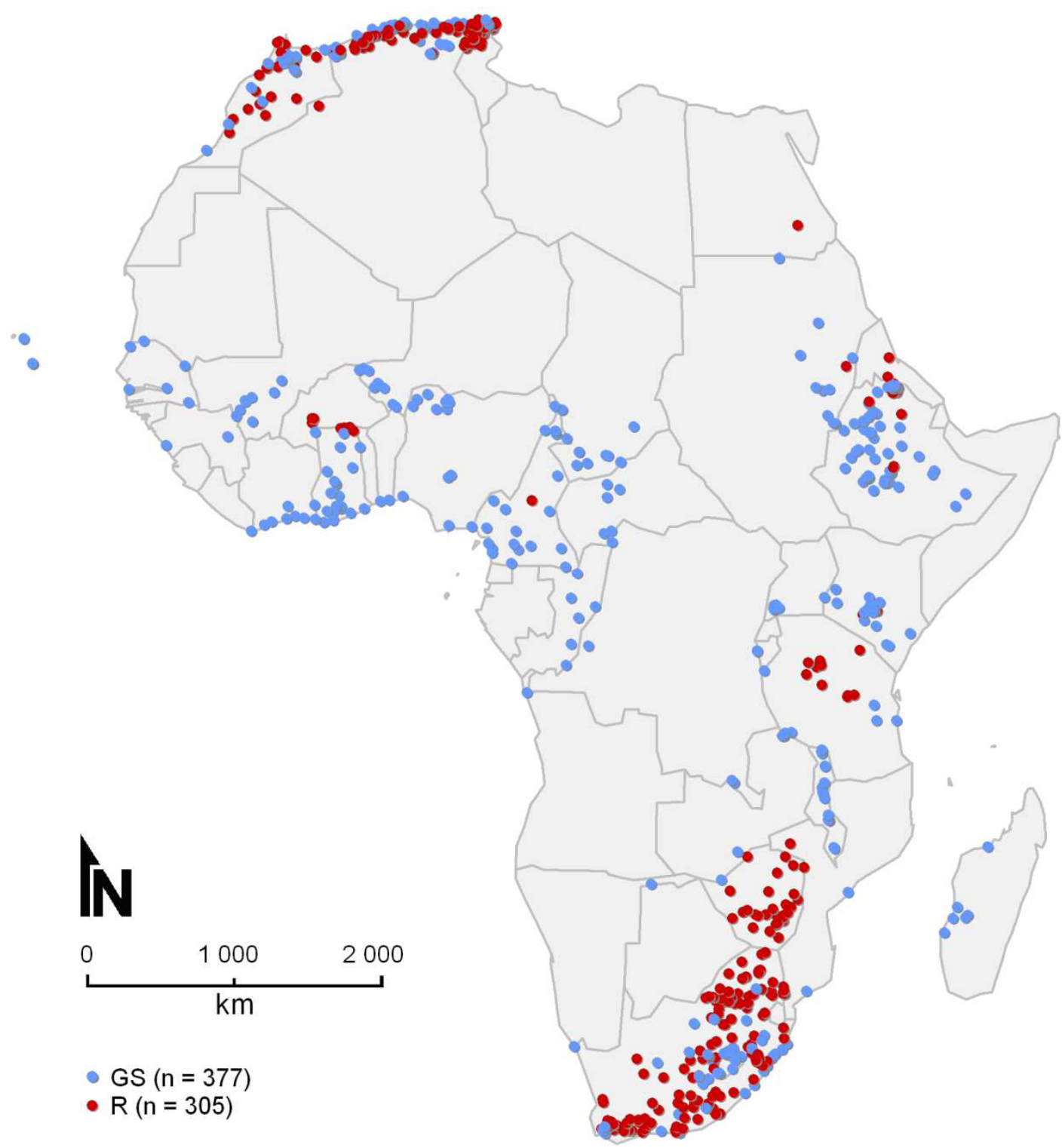

Figure 1: Location of the outlets of all African catchments for which a sediment yield measurement (SY) is available and included in this study. 'GS' = SY was derived from gauging station measurements, 'R' = SY was derived from sedimentation rates in a reservoir. 'n' = number of catchments. 


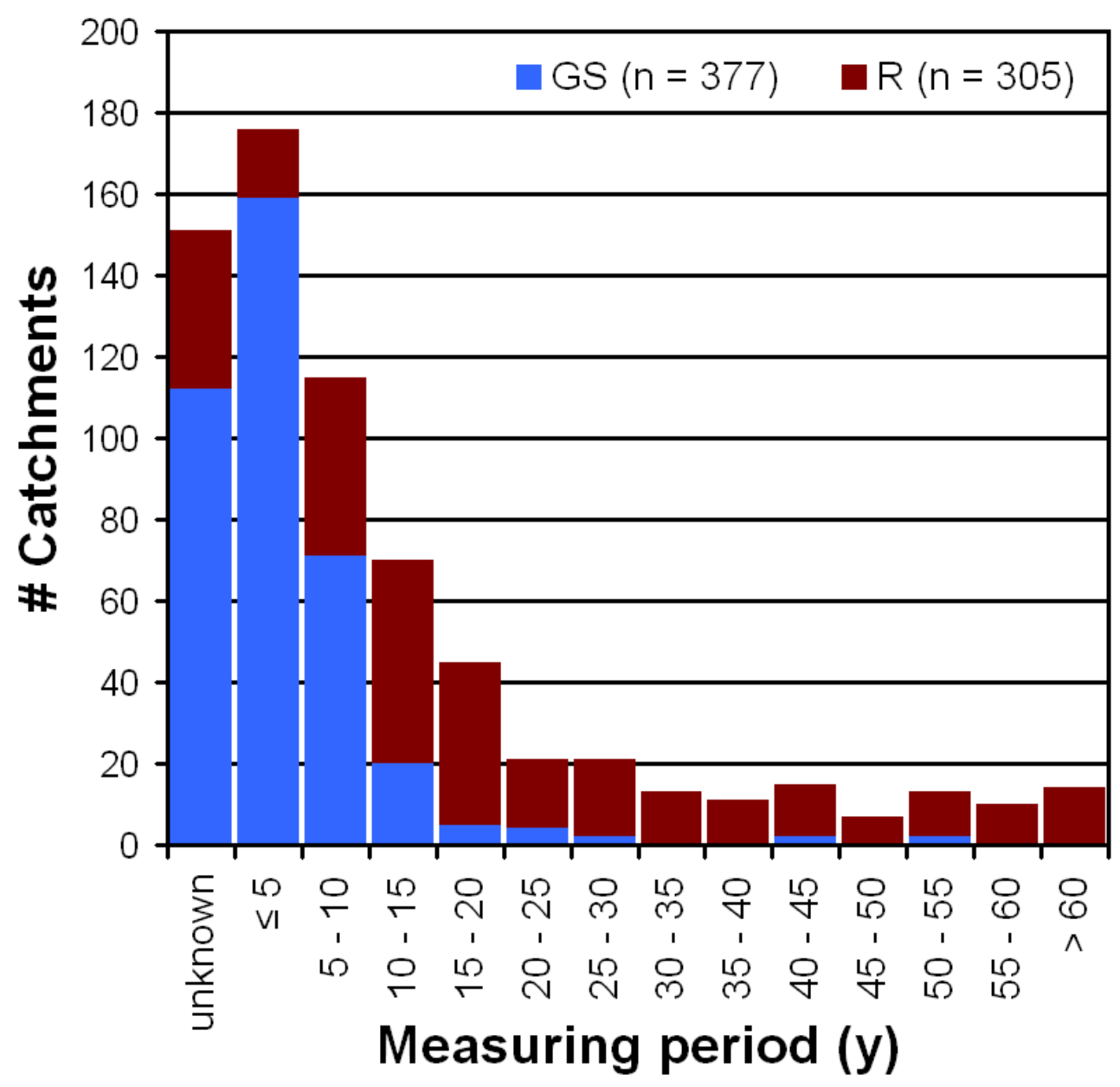

Figure 2: Number of African catchments for which sediment yield (SY) data are available, according to the measuring period of the SY observation. A subdivision is made according to the measuring method: 'GS' = SY was derived from gauging station measurements (377 catchments); 'R' = SY was derived from sedimentation rates in a reservoir (305 catchments). 


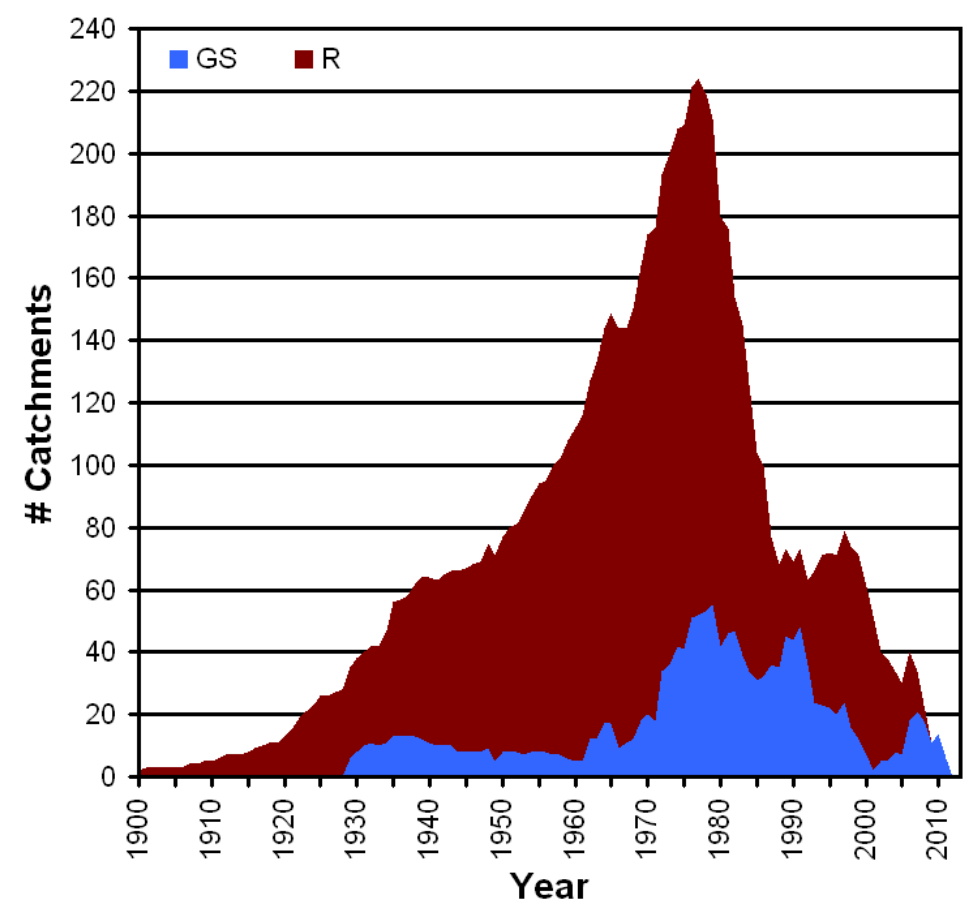

Figure 3: Temporal coverage of the catchments with a sediment yield (SY) observation for which the start and end date of the SY measurement was known $(n=495)$. A subdivision is made according to the measuring method: GS $=\mathrm{SY}$ was derived from measurements at a gauging station (250 catchments); $\mathrm{R}=\mathrm{SY}$ was derived from reservoir sedimentation rates (245 catchments). 


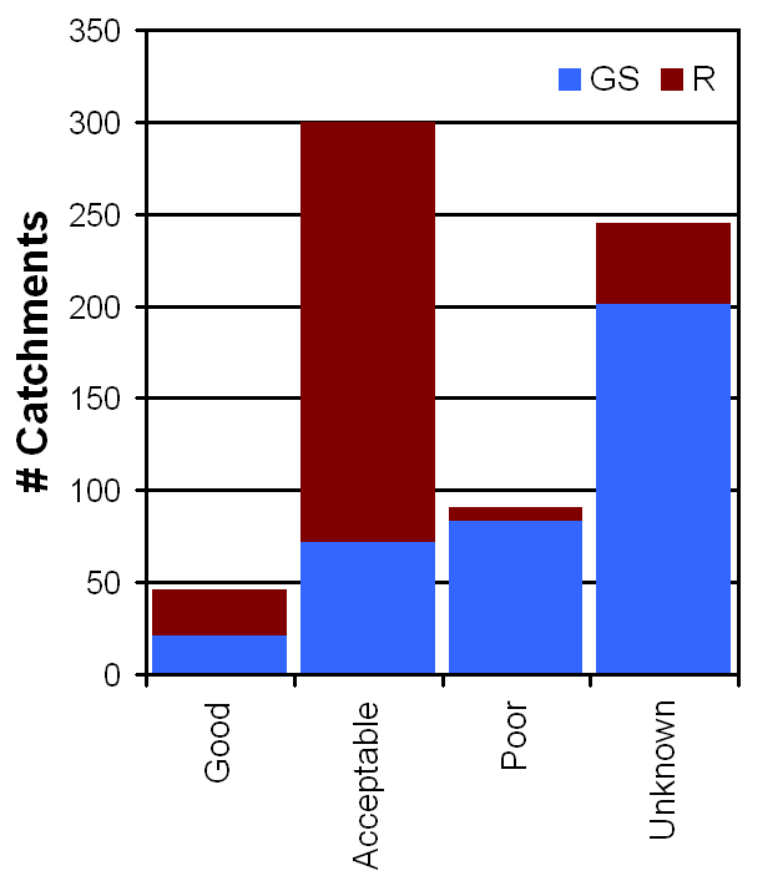

Data Quality

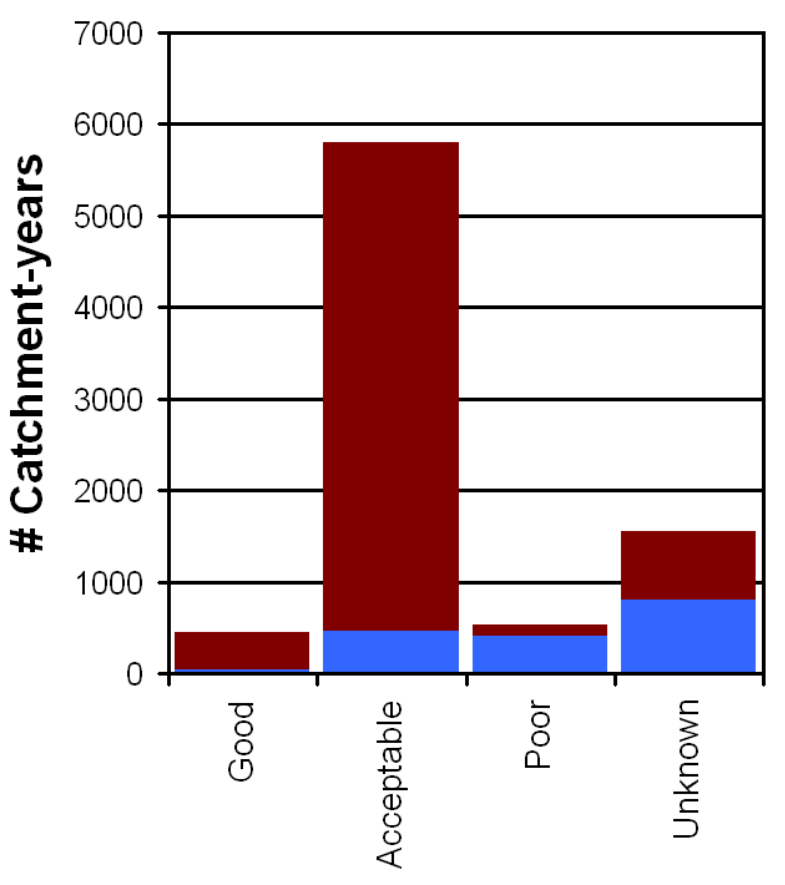

Data Quality

Figure 4: Number (\#) of catchments (left) and the corresponding number of catchment-years (right) according to the estimated quality of their sediment yield (SY) measurement. A subdivision is made according to the measuring method: 'GS' = SY was derived from gauging station measurements (377 catchments); 'R' = SY was derived from sedimentation rates in a reservoir (305 catchments). A measuring period of 1 year was assumed for SY observations with an unknown measuring period. 

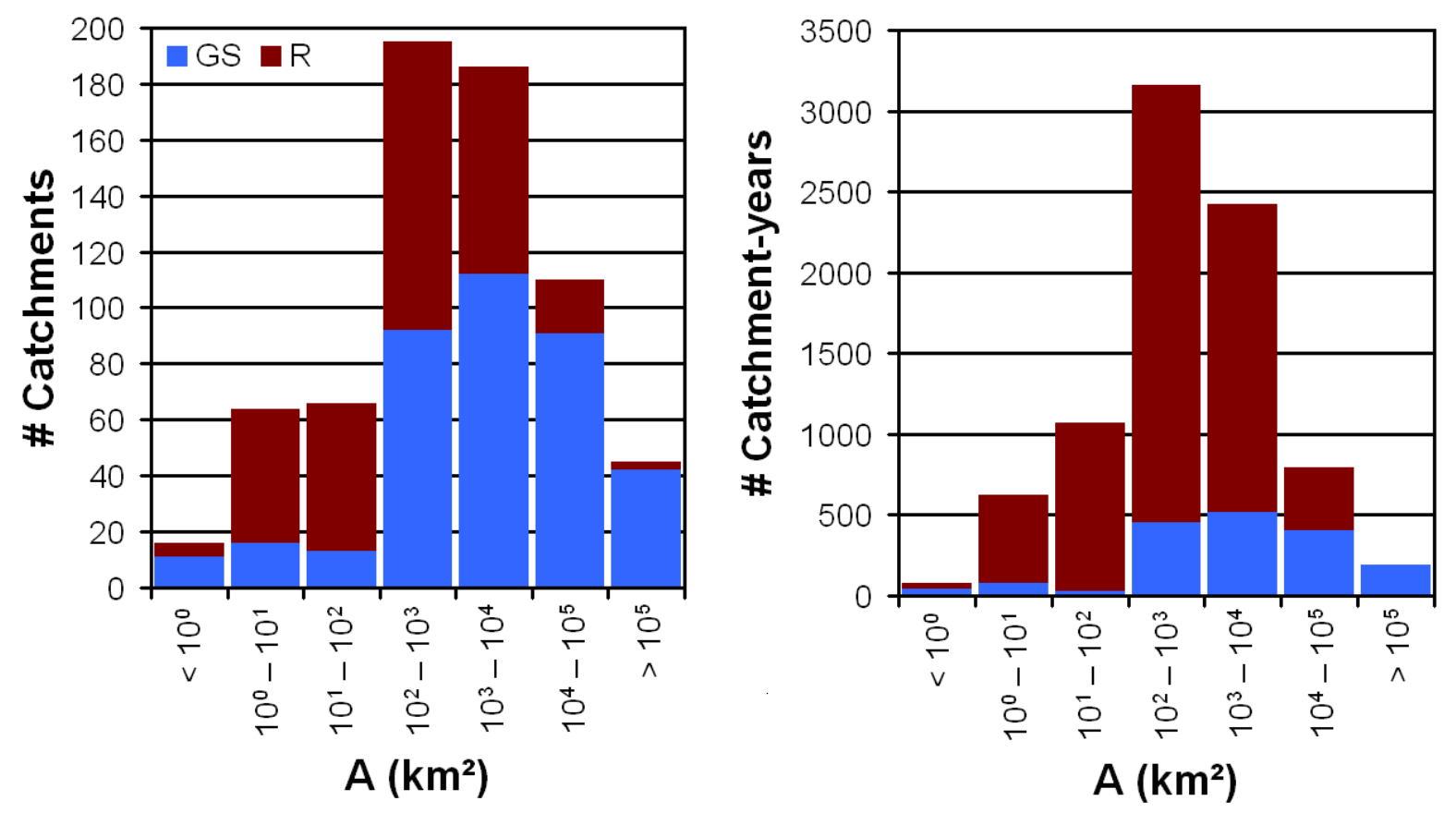

Figure 5: Number (\#) of catchments (left) for which sediment yield (SY) data are available and the corresponding number of catchment-years (right) according to the area (A) of the catchment. A subdivision is made according to the measuring method: 'GS' $=\mathrm{SY}$ was derived from gauging station measurements (377 catchments); 'R' = SY was derived from sedimentation rates in a reservoir (305 catchments). A measuring period of 1 year was assumed for SY observations with an unknown measuring period. 

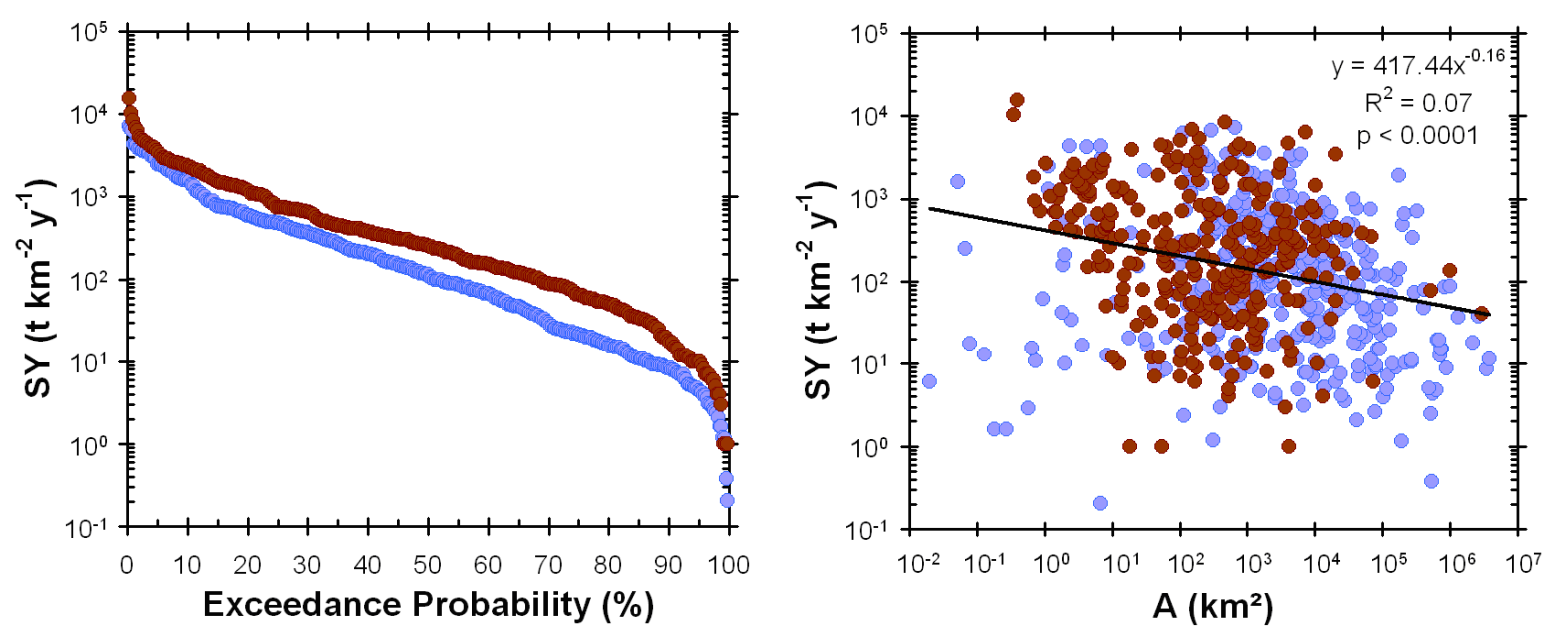

- $G S(n=377) \quad-R(n=305)$

Figure 6: Left: Exceedance Probability of all observed African catchment yields (SY) reported in this study. Right: scatter plot of these SY data and their corresponding catchment area (A). In both graphs, SY observations are subdivided according to their measuring method (GS = gauging station, $\mathrm{R}=$ reservoir). The regression (right) is based on all data $(\mathrm{n}=682)$. 


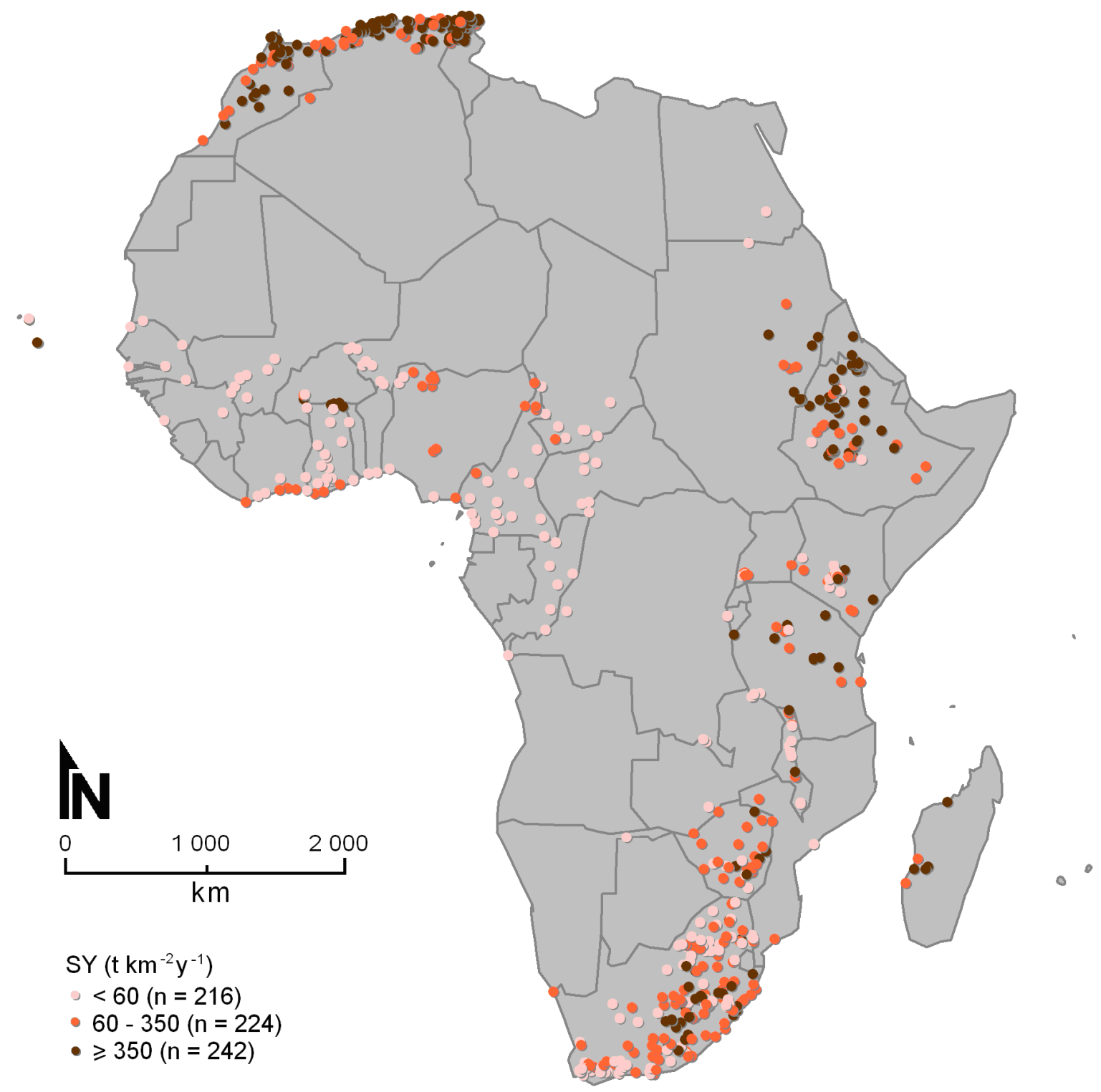

Figure 7: Catchment sediment Yield (SY) in Africa, based on all SY observations reported in this study. The subdivision in SY classes was made so that each class contains ca. one third of all the observations. Each dot corresponds to the outlet of a catchment for which SY was measured. 'n' = number of catchments. 


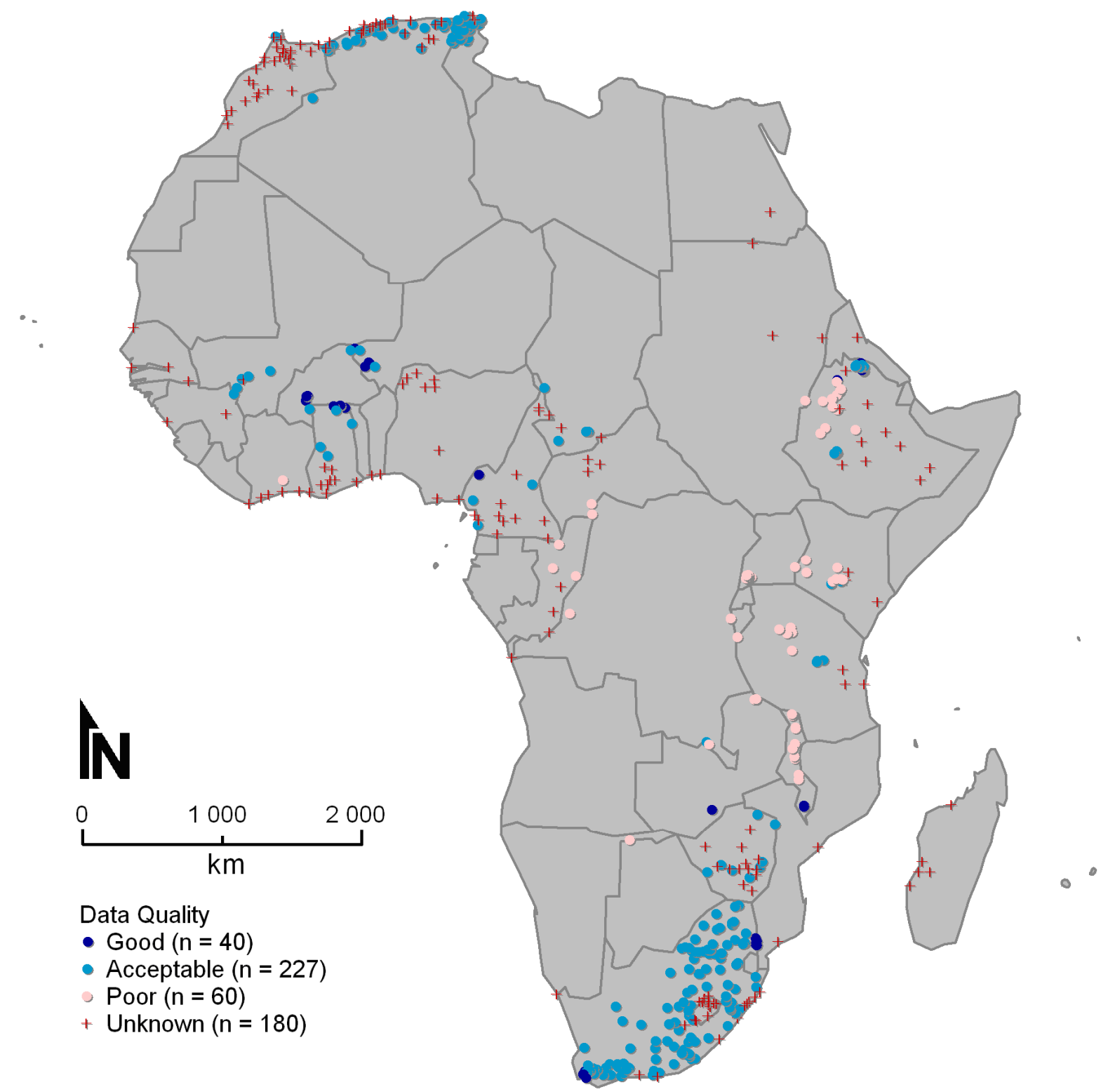

Figure 8: Location of the outlets of the 507 catchments with available sediment yield (SY) observations for which the catchment boundaries could be delineated. Symbols indicate the estimated data quality of the SY observation. 'n' = number of catchments. 

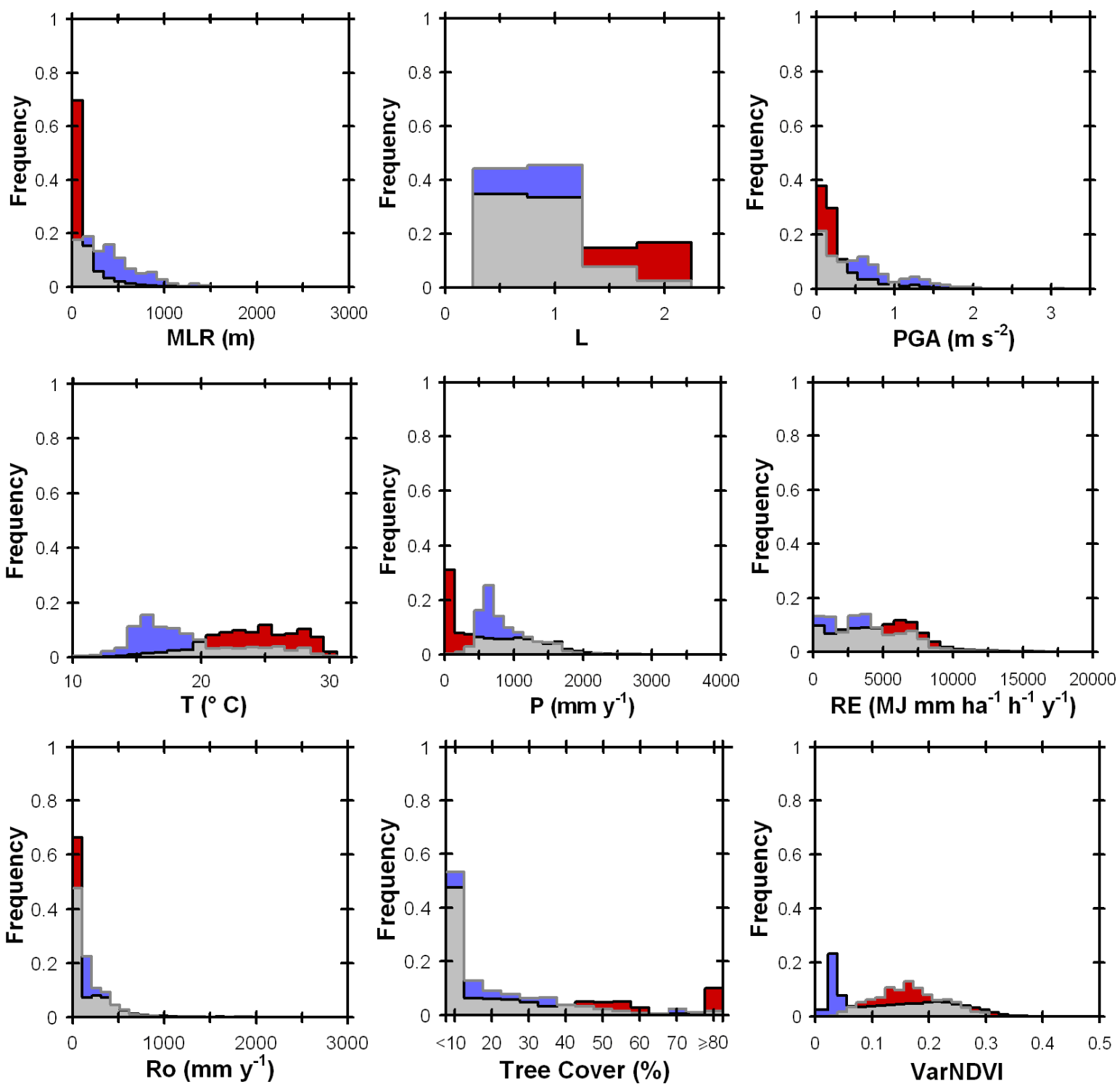

- Frequency distribution Database

Relative overrepresentation
Relative underrepresentation

Figure 9: Relative frequency distribution of catchment characteristics for the 507 catchments for which the catchment boundaries could be delineated ('Database') compared to the frequency distribution of the same characteristic for entire Africa. See table 3 for an explanation of the variables. Relative overrepresentation (underrepresentation) means that the selected catchments overrepresent (or underrepresent) the indicated range of the characteristic. 

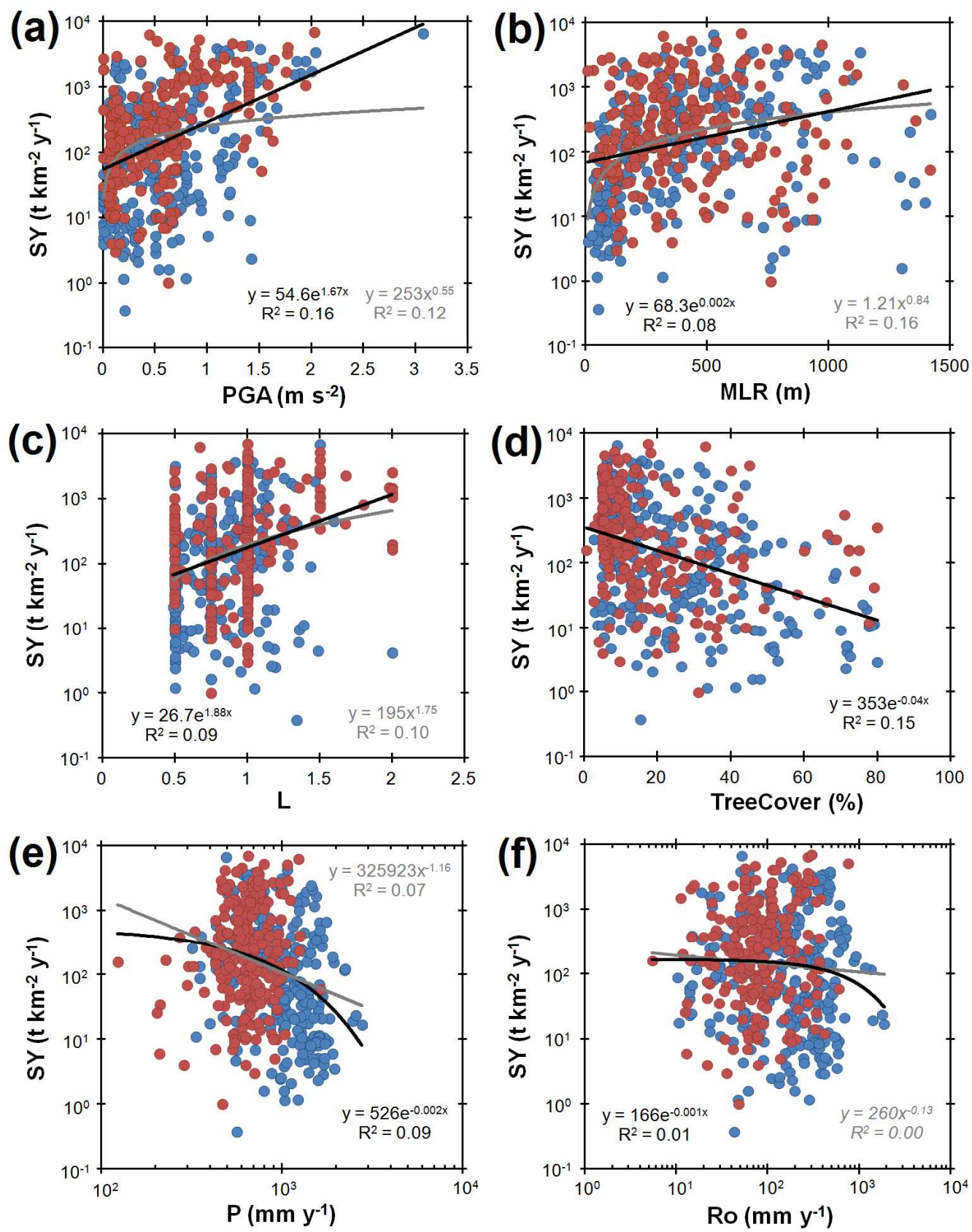

Figure 10: Scatter plots of observed catchment sediment yield (SY) and some characteristics for the 507 catchments for which the catchment boundaries could be delineated (figure 8). Blue dots represent SY observations derived from gauging station measurements $(n=269)$, while red dots represents $S Y$ values derived from reservoir sedimentation rates $(n=238)$. See table 3 for explanation of the catchment characteristics. Regressions are based on the pooled observations of both data types. The regressions in black show the best exponential fit, while regressions in grey show the best power fit. For (d) only an exponential relationship is shown since TreeCover represents a fraction. Equations in italic are insignificant at the 0.05 level (see table 4). 


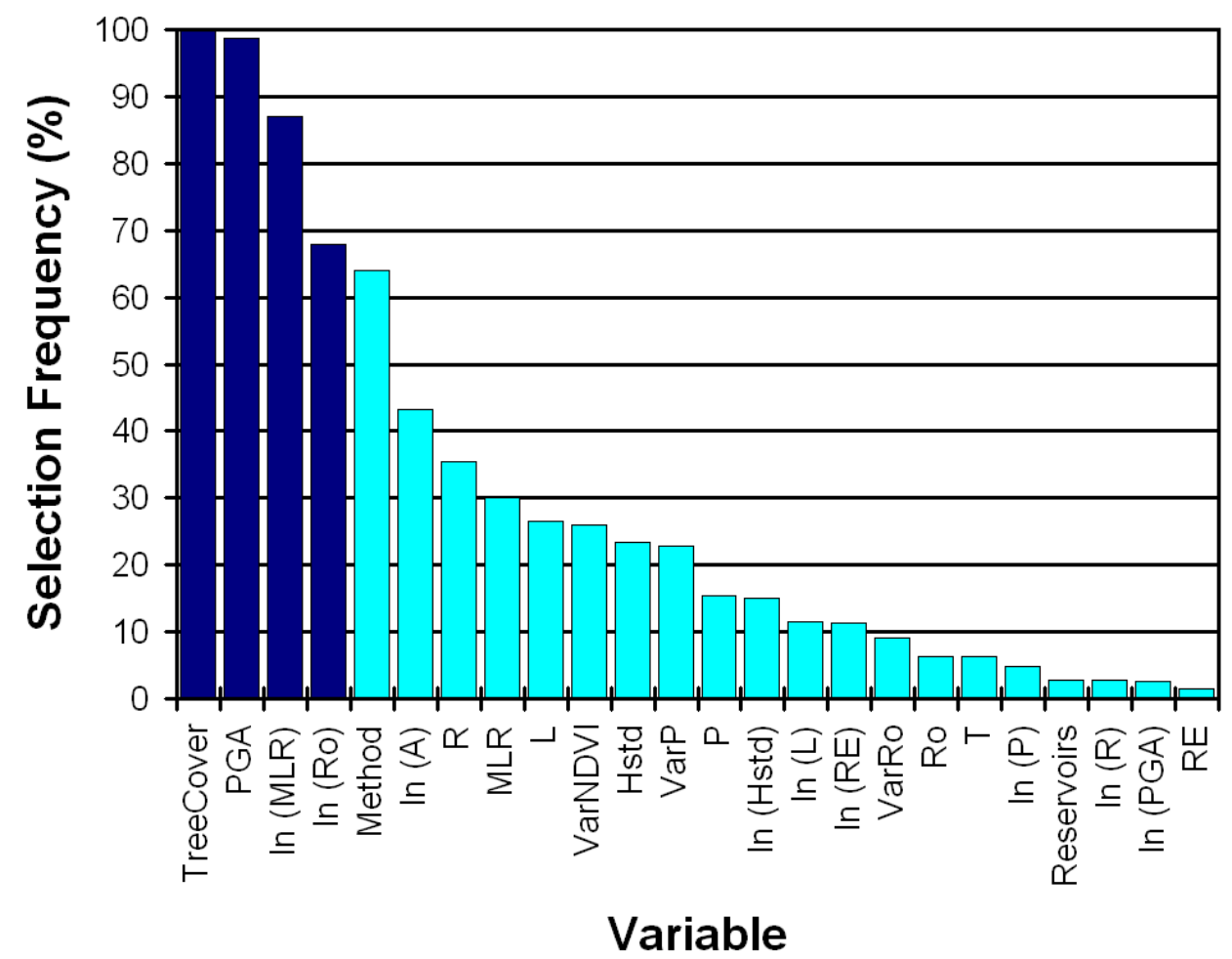

Figure 11: Frequency with which potential explaining variables were selected during an automated stepwise regression procedure to predict $\ln (\mathrm{SY})$ for 10,000 randomly selected subsets containing between 30 and $70 \%$ of the original 507 catchments for which the catchment boundaries could be delineated (see section 4.1). See table 3 for explanation of the variables. Variables in darker colour were incorporated in the proposed regression model (Eq. $1)$. 


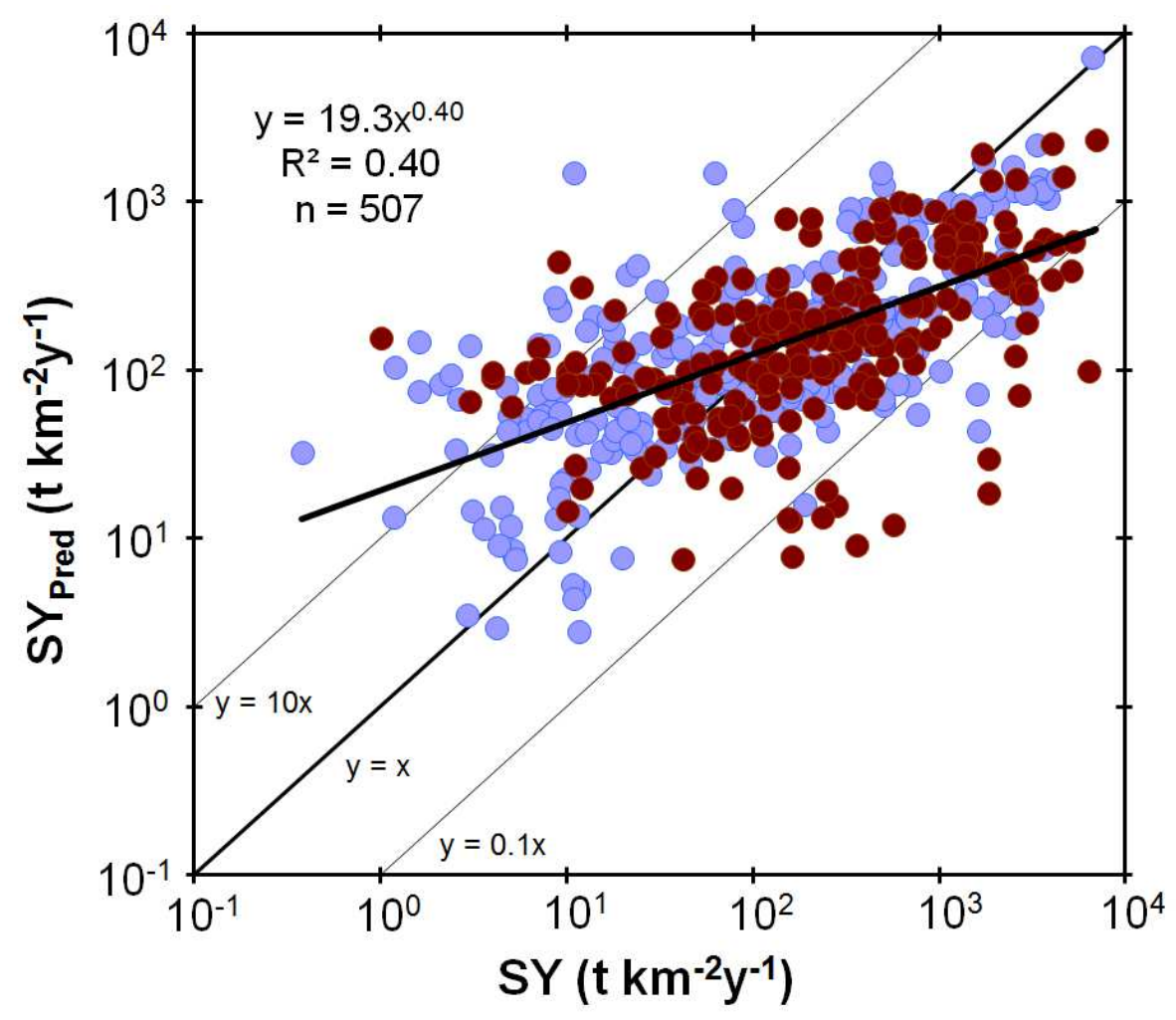

Figure 12: Observed catchment sediment yield (SY), versus the corresponding predicted value (SY $\mathrm{S}_{\text {Pred }}$ ), using the regression model (Eq. 1) for all catchments for which the catchment boundaries could be delineated (see section 4.1). 


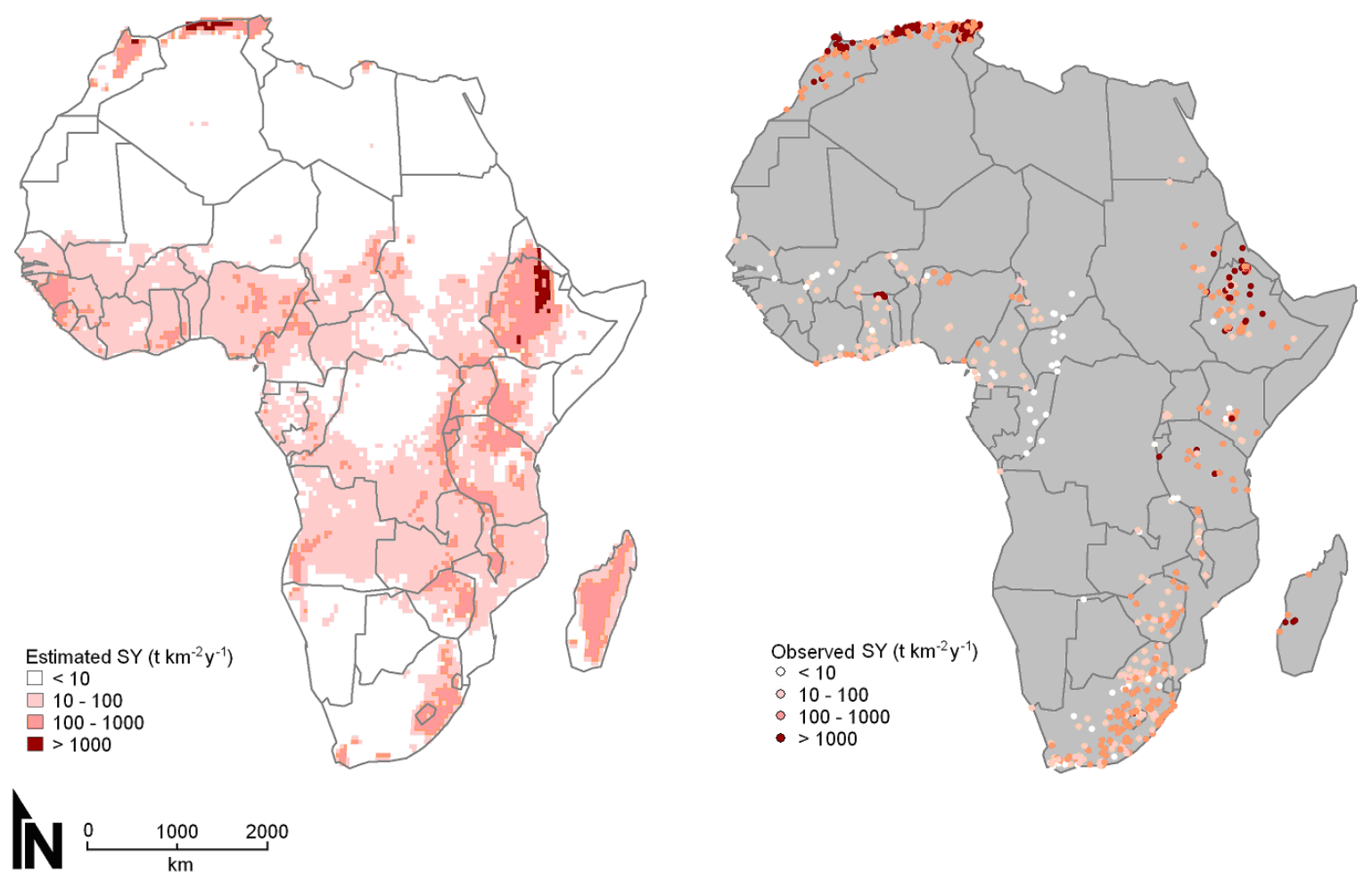

Figure 13: Left: Estimated spatial patterns of sediment yield (SY) in Africa, obtained by applying Eq. 1 to gridded datasets (table 3 ) and resampling the obtained pixel-values to a $50 \times 50 \mathrm{~km}^{2}$ resolution. Right: observed catchment sediment yields at their outlet location according to the same classification as the left map for all catchments with available SY observations $(n=682)$. 


\section{Appendix to: "Sediment Yield in Africa" Vanmaercke et al., 2014, Earth-Science Reviews}

\section{Table Explanation:}

\begin{tabular}{|c|c|}
\hline Column & Explanation \\
\hline ID & Entry identifier. \\
\hline Country & Country in which the SY observation was made. \\
\hline $\begin{array}{l}\text { River/Catchment } \\
\text { Name }\end{array}$ & Name of the river/catchment (if available). \\
\hline Measuring location & Description of the measuring location. \\
\hline Lat $\left(^{\circ}\right)$ & Estimated latitude of the measuring location. \\
\hline Lon $\left(^{\circ}\right)$ & Estimated longitude of the measuring location. \\
\hline Coord. Quality & $\begin{array}{l}\text { Estimated quality of the coordinates of the measuring location. 'A' indicates } \\
\text { that the coordinates are most likely correct and accurate, 'B' indicates that the } \\
\text { location is probably fairly accurate, but that the actual measuring location } \\
\text { may be located further up- or downstream. 'C' indicates that the coordinates } \\
\text { only provide a 'best guess' of the measuring location, subject to large } \\
\text { uncertainties. }\end{array}$ \\
\hline $\mathrm{A}\left(\mathrm{km}^{2}\right)$ & Catchment area $\left(\mathrm{km}^{2}\right)$. \\
\hline $\mathrm{SY}\left(\mathrm{t} / \mathrm{km}^{2} / \mathrm{y}\right)$ & $\begin{array}{l}\text { Area-specific catchment sediment yield. For the majority of the } \\
\text { observations, this value corresponds with the SY-value reported in the } \\
\text { indicated data source. However, in some cases the SY-value was corrected } \\
\text { for potential errors (e.g. corrected for the trapping efficiency of the resevoir) } \\
\text { or (re-)calculated based on data provided in the listed sources. It is therefore } \\
\text { recommended to also consult the original data sources, when using these SY } \\
\text { values. }\end{array}$ \\
\hline MP & $\begin{array}{l}\text { Description of the measuring period. 'HY' stands for 'Hydrological Year' (the } \\
\text { start and end date of such a year depends on the study considered). 'N.A.' } \\
\text { means that the measuring period is not available. }\end{array}$ \\
\hline MP length $(y)$ & $\begin{array}{l}\text { Duration of the measuring period in year. 'N.A.' indicates that the duration of } \\
\text { the measuring period is unknown. }\end{array}$ \\
\hline Type & $\begin{array}{l}\text { Method used to obtain the SY value. 'R' indicates that the SY value was } \\
\text { obtained from bathymetric surveys in a reservoir. 'GS' indicates that the } \\
\text { value was obtained from measurements at a gauging station. 'GS (TL)' } \\
\text { indicates that both the suspended sediment and the bedload were measured at } \\
\text { the gauging station. }\end{array}$ \\
\hline Data Quality & $\begin{array}{l}\text { Estimated quality of the } \mathrm{SY} \text { value. } \mathrm{A}=\text { good quality, } \mathrm{B}=\text { acceptebale } \\
\text { quality, } \mathrm{C}=\text { poor quality, } \mathrm{U}=\text { unknown quality. See article text for an } \\
\text { explanation of the criteria used. Please note that these estimates are only } \\
\text { based on the information available to the authors and are to some extent } \\
\text { subjective. They should be interpreted with care. }\end{array}$ \\
\hline Reference & Original references for the indicated entry. \\
\hline GIS & $\begin{array}{l}\text { Indicates whether this catchment was considered (1) or not }(0) \text { in the detailed } \\
\text { analysis of the paper (section } 4) \text {. }\end{array}$ \\
\hline
\end{tabular}




\begin{tabular}{|l|c|c|c|c|c|c|c|c|c|c|c|c|c|}
\hline ID & Country & $\begin{array}{c}\text { River/Catchment } \\
\text { Name }\end{array}$ & $\begin{array}{c}\text { Measuring } \\
\text { location }\end{array}$ & Lat $\left(^{\circ}\right)$ & Lon $\left(^{\circ}\right)$ & $\begin{array}{c}\text { Coord. } \\
\text { Quality }\end{array}$ & A $\left(\mathbf{k m}^{2}\right)$ & $\begin{array}{c}\text { SY } \\
\left(\mathbf{t} / \mathrm{km}^{2} / \mathbf{y}\right)\end{array}$ & MP & $\begin{array}{c}\text { MP } \\
\text { length } \\
(\mathbf{y})\end{array}$ & $\begin{array}{c}\text { Type } \\
\text { Quality }\end{array}$ & $\begin{array}{c}\text { Data } \\
\text { Reference }\end{array}$ \\
\hline
\end{tabular}

\begin{tabular}{|c|c|c|c|c|c|c|c|c|c|c|c|c|c|c|}
\hline 1 & Algeria & Mouilah & near Maghnia & 34.8783 & -1.7568 & B & 1680 & 126 & N.A. & N.A. & GS & $\mathrm{U}$ & Achite and Ouillon, 2007 & 1 \\
\hline 2 & Algeria & Abd & Ain Hamara & 35.4039 & 0.6797 & B & 2480 & 136 & $1973-1995$ & 23 & GS & $\mathrm{B}$ & Achite and Ouillon, 2007 & 1 \\
\hline 3 & Algeria & Leham & unknown & 35.6923 & 4.9323 & B & 5600 & 104 & N.A. & N.A. & GS & $\mathrm{U}$ & Achite and Ouillon, 2007 & 0 \\
\hline 4 & Algeria & Tleta & Ghazaouet & 35.0968 & -1.8590 & B & 100 & 297 & $1972-1979$ & 8 & GS & $\mathrm{U}$ & FAO, 2008 & 0 \\
\hline 5 & Algeria & Ressoul & Ain Berda & 36.6510 & 7.5926 & A & 103 & 214 & $1972-1979$ & 8 & GS & $\mathrm{U}$ & FAO, 2008 & 1 \\
\hline 6 & Algeria & Gueiss & F. El Gueiss & 35.4741 & 6.9377 & B & 144 & 196 & $1972-1979$ & 8 & GS & $\mathrm{U}$ & FAO, 2008 & 1 \\
\hline 7 & Algeria & Chouly & R N 7 & 34.8659 & -1.1353 & B & 170 & 75 & $1972-1979$ & 8 & GS & $\mathrm{U}$ & FAO, 2008 & 1 \\
\hline 8 & Algeria & Hachem & Bordj Ghobeni & 36.5742 & 2.2956 & B & 215 & 1542 & $1972-1979$ & 8 & GS & $\mathrm{U}$ & FAO, 2008 & 1 \\
\hline 9 & Algeria & Bouroumi & Tarzoult & 36.4152 & 2.6349 & B & 215 & 3345 & $1972-1979$ & 8 & GS & $\mathrm{U}$ & FAO, 2008 & 1 \\
\hline 10 & Algeria & Ebda & Arib Ebda & 36.3179 & 2.0247 & B & 270 & 2493 & $1972-1979$ & 8 & GS & $\mathrm{U}$ & FAO, 2008 & 1 \\
\hline 11 & Algeria & Allalah & Sidi Akacha & 36.4643 & 1.3118 & B & 295 & 6654 & $1972-1979$ & 8 & GS & $\mathrm{U}$ & FAO, 2008 & 1 \\
\hline 12 & Algeria & Reboa & Reboa & 35.5035 & 6.5090 & B & 296 & 594 & $1972-1979$ & 8 & GS & $\mathrm{U}$ & FAO, 2008 & 1 \\
\hline 13 & Algeria & Assif Tala & R N 25 & 36.7265 & 3.9521 & $\mathrm{~B}$ & 300 & 806 & $1972-1979$ & 8 & GS & $\mathrm{U}$ & FAO, 2008 & 0 \\
\hline 14 & Algeria & Chiffa & Amont des Gorges & 36.4242 & 2.7587 & $\mathrm{~B}$ & 316 & 2461 & $1972-1979$ & 8 & GS & $\mathrm{U}$ & FAO, 2008 & 1 \\
\hline 15 & Algeria & El Harrach & $\begin{array}{l}\text { Hammam } \\
\text { Melouane }\end{array}$ & 36.4880 & 3.0450 & B & 387 & 1630 & $1972-1979$ & 8 & GS & $\mathrm{U}$ & FAO, 2008 & 1 \\
\hline 16 & Algeria & Djer & El Aferoun & 36.4705 & 2.6172 & B & 395 & 1729 & $1972-1979$ & 8 & GS & $\mathrm{U}$ & FAO, 2008 & 1 \\
\hline 17 & Algeria & Haddad & S. A. Djillali & 35.3852 & 0.4931 & $\mathrm{~B}$ & 470 & 103 & $1972-1979$ & 8 & GS & $\mathrm{U}$ & FAO, 2008 & 0 \\
\hline 18 & Algeria & Hamman & Zit Emba & 36.6460 & 7.3211 & $\mathrm{C}$ & 485 & 197 & $1972-1979$ & 8 & GS & $\mathrm{U}$ & FAO, 2008 & 0 \\
\hline 19 & Algeria & Deurdeur & Sidi Mokrebi & 36.1295 & 2.2672 & $\mathrm{C}$ & 500 & 223 & $1972-1979$ & 8 & GS & $\mathrm{U}$ & FAO, 2008 & 0 \\
\hline 20 & Algeria & Melah & Bouchegoue & 35.6322 & 0.5429 & B & 550 & 716 & $1972-1979$ & 8 & GS & $\mathrm{U}$ & FAO, 2008 & 0 \\
\hline 21 & Algeria & Kebir Est & Ain El Assel & 36.7938 & 8.3739 & $\mathrm{C}$ & 680 & 903 & $1972-1979$ & 8 & GS & $\mathrm{U}$ & FAO, 2008 & 0 \\
\hline 22 & Algeria & Rouina & Rouina Mines & 36.2515 & 1.8143 & B & 865 & 1151 & $1972-1979$ & 8 & GS & $\mathrm{U}$ & FAO, 2008 & 1 \\
\hline 23 & Algeria & El Abiod & Mchouneche & 34.9429 & 5.9974 & B & 1050 & 401 & $1972-1979$ & 8 & GS & $\mathrm{U}$ & FAO, 2008 & 1 \\
\hline 24 & Algeria & Kebir Ouest & Ain Charchar & 36.7432 & 7.2434 & B & 1130 & 92 & $1972-1979$ & 8 & GS & $\mathrm{U}$ & FAO, 2008 & 0 \\
\hline 25 & Algeria & Sly & Ouled B. Aek & 36.0265 & 1.2657 & B & 1225 & 2037 & $1972-1979$ & 8 & GS & $\mathrm{U}$ & FAO, 2008 & 1 \\
\hline 26 & Algeria & Ksob & Medjez & 35.8845 & 4.6168 & B & 1330 & 333 & $1972-1979$ & 8 & GS & $\mathrm{U}$ & FAO, 2008 & 1 \\
\hline 27 & Algeria & Rhiou & Ammi Moussa & 35.8684 & 1.1155 & B & 1890 & 1822 & $1972-1979$ & 8 & GS & $\mathrm{U}$ & FAO, 2008 & 1 \\
\hline 28 & Algeria & El Arab & Khanga S Nadat & 35.3589 & 7.1717 & B & 2085 & 539 & $1972-1979$ & 8 & GS & $\mathrm{U}$ & FAO, 2008 & 0 \\
\hline 29 & Algeria & Bousellah & Magraoua & 36.4651 & 5.9054 & B & 2350 & 99 & $1972-1979$ & 8 & GS & $\mathrm{U}$ & FAO, 2008 & 0 \\
\hline 30 & Algeria & Mouilah & Maghnia & 34.8792 & -1.6917 & A & 2650 & 163.3 & $\begin{array}{c}\text { Sept } 1977 \text { - Aug } \\
1995\end{array}$ & 18 & GS & B & Ghenim et al., 2008 & 1 \\
\hline 31 & Algeria & Bou Namoussa & unknown & 36.6633 & 7.9531 & B & 575 & 270 & N.A. & N.A. & GS & $\mathrm{U}$ & Hooke, 2006 & 0 \\
\hline
\end{tabular}




\begin{tabular}{|c|c|c|c|c|c|c|c|c|c|c|c|c|c|c|}
\hline ID & Country & $\begin{array}{c}\text { River/Catchment } \\
\text { Name }\end{array}$ & $\begin{array}{c}\text { Measuring } \\
\text { location }\end{array}$ & Lat $\left(^{\circ}\right)$ & Lon $\left(^{\circ}\right)$ & $\begin{array}{l}\text { Coord. } \\
\text { Quality }\end{array}$ & $\mathbf{A}\left(\mathbf{k m}^{2}\right)$ & $\underset{\left(\mathbf{t} / \mathbf{k m}^{2} / \mathbf{y}\right)}{\mathbf{S Y}}$ & MP & $\begin{array}{c}\text { MP } \\
\text { length } \\
(\mathbf{y})\end{array}$ & Type & $\begin{array}{c}\text { Data } \\
\text { Quality }\end{array}$ & Reference & GIS \\
\hline & & & & & & & & & & & & & & \\
\hline 32 & Algeria & Bou Hamdane & $\begin{array}{l}\text { near Bou } \\
\text { Hamdane }\end{array}$ & 36.4662 & 7.1125 & B & 1165 & 88 & N.A. & N.A. & GS & $\mathrm{U}$ & Hooke, 2006 & 1 \\
\hline 33 & Algeria & Mellah & Bouchegouf & 36.4590 & 7.7129 & B & 550 & 562 & 1975 - 1999 & 24 & GS & B & Kanchoul et al., 2009 & 1 \\
\hline 34 & Algeria & & Hamiz & 36.6041 & 3.3519 & B & 139 & 1065.8 & $1935-1986$ & 52 & $\mathrm{R}$ & B & $\begin{array}{l}\text { Lahlou, 1996; } \\
\text { Bengueddach and } \\
\text { Chabouni, } 1997\end{array}$ & 1 \\
\hline 35 & Algeria & & Lekhal & 36.2587 & 3.7153 & B & 189 & 1709 & $1986-? ?$ & N.A. & $\mathrm{R}$ & B & $\begin{array}{l}\text { Lahlou, 1996; } \\
\text { Bengueddach and } \\
\text { Chabouni, } 1997\end{array}$ & 1 \\
\hline 36 & Algeria & & Ain Dalia & 36.2730 & 7.8236 & B & 193 & 5281.3 & $1989-? ?$ & N.A. & $\mathrm{R}$ & B & $\begin{array}{l}\text { Lahlou, 1996; } \\
\text { Bengueddach and } \\
\text { Chabouni, } 1997\end{array}$ & 1 \\
\hline 37 & Algeria & & Meffrouch & 34.9637 & -1.4531 & B & 264 & 63.4 & $1962-1986$ & 25 & $\mathrm{R}$ & B & $\begin{array}{c}\text { Lahlou, 1996; } \\
\text { Bengueddach and } \\
\text { Chabouni, } 1997\end{array}$ & 1 \\
\hline 38 & Algeria & & Sarno & 35.2453 & 0.5969 & B & 264 & 719.9 & $1953-1986$ & 34 & $\mathrm{R}$ & B & $\begin{array}{l}\text { Lahlou, 1996; } \\
\text { Bengueddach and } \\
\text { Chabouni, } 1997\end{array}$ & 0 \\
\hline 40 & Algeria & & Zardezas & 36.5892 & 6.8987 & $\mathrm{C}$ & 570 & 606.3 & $1948-1985$ & 38 & $\mathrm{R}$ & B & $\begin{array}{l}\text { Lahlou, 1996; } \\
\text { Bengueddach and } \\
\text { Chabouni, } 1997\end{array}$ & 0 \\
\hline 41 & Algeria & & Ighil Emda & 36.4696 & 5.2666 & B & 652 & 4039.5 & $1954-1986$ & 33 & $\mathrm{R}$ & B & $\begin{array}{c}\text { Lahlou, 1996; } \\
\text { Bengueddach and } \\
\text { Chabouni, } 1997\end{array}$ & 1 \\
\hline 42 & Algeria & & near Beni Bahdel & 34.7029 & -1.5019 & B & 1016 & 145.6 & $1938-1986$ & 49 & $\mathrm{R}$ & B & $\begin{array}{l}\text { Lahlou, 1996; } \\
\text { Bengueddach and } \\
\text { Chabouni, } 1997\end{array}$ & 1 \\
\hline 43 & Algeria & & H. Grouz & 36.2271 & 6.2790 & B & 1220 & 414.6 & $1988-? ?$ & N.A. & $\mathrm{R}$ & B & $\begin{array}{l}\text { Lahlou, 1996; } \\
\text { Bengueddach and } \\
\text { Chabouni, } 1997\end{array}$ & 1 \\
\hline 44 & Algeria & & Bakhada & 35.3377 & 1.0545 & B & 1300 & 193.1 & $1936-1986$ & 51 & $\mathrm{R}$ & B & $\begin{array}{l}\text { Lahlou, 1996; } \\
\text { Bengueddach and } \\
\text { Chabouni, } 1997\end{array}$ & 1 \\
\hline 45 & Algeria & & F.E. Gherza & 34.8598 & 5.9238 & B & 1300 & 480.1 & $1952-1986$ & 35 & $\mathrm{R}$ & B & $\begin{array}{c}\text { Lahlou, 1996; } \\
\text { Bengueddach and } \\
\text { Chabouni, } 1997\end{array}$ & 1 \\
\hline
\end{tabular}




\begin{tabular}{|l|c|c|c|c|c|c|c|c|c|c|c|c|c|}
\hline ID & Country & $\begin{array}{c}\text { River/Catchment } \\
\text { Name }\end{array}$ & $\begin{array}{c}\text { Measuring } \\
\text { location }\end{array}$ & Lat $\left(^{\circ}\right)$ & Lon $\left(^{\circ}\right)$ & $\begin{array}{c}\text { Coord. } \\
\text { Quality }\end{array}$ & A $\left(\mathbf{k m}^{2}\right)$ & $\begin{array}{c}\text { SY } \\
\left(\mathbf{t} / \mathrm{km}^{2} / \mathbf{y}\right)\end{array}$ & MP & $\begin{array}{c}\text { MP } \\
\text { length } \\
(\mathbf{y})\end{array}$ & $\begin{array}{c}\text { Type } \\
\text { Quality }\end{array}$ & $\begin{array}{c}\text { Data } \\
\text { Reference }\end{array}$ \\
\hline
\end{tabular}

\begin{tabular}{|c|c|c|c|c|c|c|c|c|c|c|c|c|c|c|}
\hline 46 & Algeria & & K'sob & 35.8394 & 4.5665 & B & 1500 & 205.6 & $1939-1986$ & 48 & $\mathrm{R}$ & B & $\begin{array}{l}\text { Lahlou, 1996; } \\
\text { Bengueddach and } \\
\text { Chabouni, } 1997\end{array}$ & 1 \\
\hline 47 & Algeria & & Beni Amrane & 36.6697 & 3.6079 & B & 3170 & 2598.4 & N.A. & N.A. & $\mathrm{R}$ & $\mathrm{B}$ & $\begin{array}{l}\text { Lahlou, 1996; } \\
\text { Bengueddach and } \\
\text { Chabouni, } 1997\end{array}$ & 1 \\
\hline 48 & Algeria & & Bouhanifia & 35.2808 & -0.0715 & B & 7850 & 112.4 & $1948-1985$ & 38 & $\mathrm{R}$ & $\mathrm{B}$ & $\begin{array}{l}\text { Lahlou, 1996; } \\
\text { Bengueddach and } \\
\text { Chabouni, } 1997\end{array}$ & 1 \\
\hline 49 & Algeria & & Boughzoul & 35.7435 & 2.7919 & B & 20500 & 454.8 & $1934-1986$ & 53 & $\mathrm{R}$ & B & $\begin{array}{l}\text { Lahlou, 1996; } \\
\text { Bengueddach and } \\
\text { Chabouni, } 1997\end{array}$ & 1 \\
\hline 50 & Algeria & & Djorf Torba & 31.5295 & -2.7609 & B & 22000 & 160.4 & $1969-1985$ & 17 & $\mathrm{R}$ & B & $\begin{array}{l}\text { Lahlou, 1996; } \\
\text { Bengueddach and } \\
\text { Chabouni, } 1997 \\
\end{array}$ & 1 \\
\hline 51 & Algeria & El Harrach & near outlet & 36.7356 & 3.1120 & B & 390 & 1615.4 & N.A. & N.A. & GS & $\mathrm{U}$ & $\begin{array}{l}\text { Milliman and Fansworth, } \\
2011\end{array}$ & 0 \\
\hline 52 & Algeria & Agrioun & near outlet & 36.6443 & 5.3439 & B & 660 & 7272.7 & N.A. & N.A. & GS & $\mathrm{U}$ & $\begin{array}{l}\text { Milliman and Fansworth, } \\
2011 \\
\end{array}$ & 0 \\
\hline 53 & Algeria & Kebir & near outlet & 36.8685 & 6.1024 & B & 1100 & 200 & N.A. & N.A. & GS & $\mathrm{U}$ & $\begin{array}{l}\text { Milliman and Fansworth, } \\
2011\end{array}$ & 0 \\
\hline 54 & Algeria & Mazafran & near outlet & 36.6840 & 2.7813 & B & 1900 & 1578.9 & N.A. & N.A. & GS & $\mathrm{U}$ & $\begin{array}{l}\text { Milliman and Fansworth, } \\
2011\end{array}$ & 0 \\
\hline 55 & Algeria & Sebaou & near outlet & 36.9083 & 3.8408 & B & 2500 & 480 & N.A. & N.A. & GS & $\mathrm{U}$ & $\begin{array}{l}\text { Milliman and Fansworth, } \\
2011\end{array}$ & 0 \\
\hline 56 & Algeria & Isser & near outlet & 36.8288 & 3.6585 & B & 4200 & 1976.2 & N.A. & N.A. & GS & $\mathrm{U}$ & $\begin{array}{l}\text { Milliman and Fansworth, } \\
2011\end{array}$ & 1 \\
\hline 57 & Algeria & Seybousse & near outlet & 36.8789 & 7.7711 & B & 5500 & 218.2 & N.A. & N.A. & GS & $\mathrm{U}$ & $\begin{array}{l}\text { Milliman and Fansworth, } \\
2011\end{array}$ & 0 \\
\hline 58 & Algeria & Soumman & near outlet & 36.7293 & 5.0892 & B & 8500 & 482.4 & N.A. & N.A. & GS & $\mathrm{U}$ & $\begin{array}{l}\text { Milliman and Fansworth, } \\
2011\end{array}$ & 1 \\
\hline 59 & Algeria & Tafna & near outlet & 35.2966 & -1.4617 & B & 8800 & 113.6 & N.A. & N.A. & GS & $\mathrm{U}$ & $\begin{array}{l}\text { Milliman and Fansworth, } \\
2011\end{array}$ & 1 \\
\hline 60 & Algeria & Cheliff & near outlet & 36.0352 & 0.1341 & B & 44000 & 90.9 & N.A. & N.A. & GS & $\mathrm{U}$ & $\begin{array}{l}\text { Milliman and Fansworth, } \\
2011\end{array}$ & 1 \\
\hline 61 & Algeria & Haute Tafna & near Beni Bahdel & 34.6972 & -1.4787 & $\mathrm{~B}$ & 256 & 3000 & $1989-1998$ & 10 & GS & $\mathrm{U}$ & Terfous et al., 2003 & 0 \\
\hline 62 & Algeria & Isser & El Izdibar & 34.8519 & 5.7384 & $\mathrm{C}$ & 1140 & 117 & $1989-1998$ & 10 & GS & $\mathrm{U}$ & Terfous et al., 2003 & 0 \\
\hline 63 & Algeria & & Keddara & 36.6485 & 3.4210 & A & 93 & 3215 & $1987-2001$ & 15 & $\mathrm{R}$ & $\mathrm{B}$ & Touaibia, 2010 & 1 \\
\hline 64 & Algeria & & Bouroumi & 36.3562 & 2.5582 & A & 150 & 6933 & 1986 - 2001 & 16 & $\mathrm{R}$ & $\mathrm{B}$ & Touaibia, 2010 & 1 \\
\hline
\end{tabular}




\begin{tabular}{|c|c|c|c|c|c|c|c|c|c|c|c|c|c|c|}
\hline ID & Country & $\begin{array}{c}\text { River/Catchment } \\
\text { Name }\end{array}$ & $\begin{array}{l}\text { Measuring } \\
\text { location }\end{array}$ & Lat $\left(^{\circ}\right)$ & Lon $\left(^{\circ}\right)$ & $\begin{array}{l}\text { Coord. } \\
\text { Quality }\end{array}$ & $\mathbf{A}\left(\mathbf{k m}^{2}\right)$ & $\underset{\left(\mathbf{t} / \mathbf{k m}^{2} / \mathbf{y}\right)}{\mathbf{S Y}}$ & MP & $\begin{array}{c}\text { MP } \\
\text { length } \\
\text { (y) }\end{array}$ & Type & $\begin{array}{l}\text { Data } \\
\text { Quality }\end{array}$ & Reference & GIS \\
\hline & & & & & & & & & & & & & & \\
\hline 65 & Algeria & Oued Rherga & Guenitra & 36.5838 & 6.9039 & A & 202 & 837 & $1984-2001$ & 18 & $\mathrm{R}$ & B & Touaibia, 2010 & 0 \\
\hline 66 & Algeria & & Deurdeur & 35.9968 & 2.2321 & A & 468 & 2306 & $1985-2001$ & 17 & $\mathrm{R}$ & B & Touaibia, 2010 & 1 \\
\hline 67 & Algeria & & Cheffia & 36.6228 & 8.0589 & A & 575 & 2713 & $1965-2001$ & 37 & $\mathrm{R}$ & $\mathrm{B}$ & Touaibia, 2010 & 1 \\
\hline 68 & Algeria & Fodda & Oued Fodda & 36.0268 & 1.5981 & A & 800 & 2400 & $1932-2001$ & 70 & $\mathrm{R}$ & B & Touaibia, 2010 & 1 \\
\hline 69 & Algeria & & Sidi Yacoub & 35.9757 & 1.3133 & B & 920 & 1490 & $1985-2001$ & 17 & $\mathrm{R}$ & B & Touaibia, 2010 & 1 \\
\hline 71 & Algeria & & Hammam Debagh & 36.4708 & 7.2183 & $\mathrm{~A}$ & 1070 & 505 & $1987-2001$ & 15 & $\mathrm{R}$ & $\mathrm{B}$ & Touaibia, 2010 & 1 \\
\hline 72 & Algeria & & Sidi Abdelli & 35.0986 & -1.1312 & $\mathrm{~A}$ & 1100 & 210 & $1988-2001$ & 14 & $\mathrm{R}$ & $\mathrm{B}$ & Touaibia, 2010 & 1 \\
\hline 73 & Algeria & & Oued Cherf & 36.4621 & 7.2385 & $\mathrm{~A}$ & 1735 & 300 & $1995-2001$ & 7 & $\mathrm{R}$ & $\mathrm{B}$ & Touaibia, 2010 & 0 \\
\hline 74 & Algeria & & Ouizert & 35.1198 & -0.0328 & $\mathrm{~B}$ & 2100 & 260 & $1987-2001$ & 15 & $\mathrm{R}$ & $\mathrm{B}$ & Touaibia, 2010 & 1 \\
\hline 75 & Algeria & Ghrib & Ghrib & 36.1462 & 2.5680 & $\mathrm{~B}$ & 2800 & 750 & $1939-2001$ & 63 & $\mathrm{R}$ & B & Touaibia, 2010 & 0 \\
\hline 76 & Algeria & & Gargar & 35.9158 & 1.0031 & $\mathrm{~B}$ & 2900 & 2062 & $1988-2001$ & 14 & $\mathrm{R}$ & $\mathrm{B}$ & Touaibia, 2010 & 1 \\
\hline 77 & Algeria & & Sidi M. Bénaouda & 35.5634 & 0.6009 & $\mathrm{~B}$ & 4900 & 336 & $1978-2001$ & 24 & $\mathrm{R}$ & $\mathrm{B}$ & Touaibia, 2010 & 0 \\
\hline 78 & Benin & Oueme & near outlet & 6.3394 & 2.4634 & B & 50000 & 48 & N.A. & N.A. & GS & $\mathrm{U}$ & $\begin{array}{l}\text { Milliman and Fansworth, } \\
2011\end{array}$ & 1 \\
\hline 79 & Botswana & Okavango & $\begin{array}{l}\text { inlet of Okavango } \\
\text { delta }\end{array}$ & -18.2696 & 21.7792 & $\mathrm{C}$ & 530000 & 0.4 & N.A. & N.A. & $\begin{array}{l}\mathrm{GS} \\
(\mathrm{TL})\end{array}$ & $\mathrm{C}$ & $\begin{array}{l}\text { McCarthy and Metcalfe, } \\
1990\end{array}$ & 1 \\
\hline 80 & Burkina Faso & Dano & $\begin{array}{c}\text { Barrage du } \\
\text { Moutori }\end{array}$ & 11.2547 & -3.1398 & A & 7.9 & 440.8 & $2002-2006$ & 4 & $\mathrm{R}$ & A & Schmengler, 2011 & 1 \\
\hline 81 & Burkina Faso & Wahable & $\begin{array}{l}\text { Barrage de } \\
\text { Wahable }\end{array}$ & 11.5333 & -3.1333 & A & 15 & 81.9 & $1988-2005$ & 17 & $\mathrm{R}$ & A & Schmengler, 2011 & 1 \\
\hline 82 & Burkina Faso & Fafo & Barrage de Fafo & 11.5451 & -3.0208 & $\mathrm{~B}$ & 24 & 29.5 & $1988-2006$ & 18 & $\mathrm{R}$ & A & Schmengler, 2011 & 1 \\
\hline 83 & Cameroon & & Foumban & 5.7257 & 10.9009 & $\mathrm{C}$ & 1350 & 15 & N.A. & 1 & GS & $\mathrm{U}$ & $\begin{array}{c}\text { Dedkov and Mozzherin, } \\
1984 \\
\end{array}$ & 0 \\
\hline 84 & Cameroon & Djerem & Mbakaou & 6.3077 & 12.8115 & B & 20400 & 59 & N.A. & 1 & $\mathrm{R}$ & $\mathrm{U}$ & $\begin{array}{c}\text { Dedkov and Mozzherin, } \\
1984 \\
\end{array}$ & 1 \\
\hline 85 & Cameroon & Mengong & Nsimi & 3.1690 & 11.8123 & A & 0.58 & 2.9 & $1994-1996$ & 3 & GS & $\mathrm{U}$ & Liénou et al., 2005 & 1 \\
\hline 86 & Cameroon & Mayo Boula & Dargala & 10.5321 & 14.6005 & $\mathrm{~B}$ & 1517 & 221 & $1985-1986$ & 2 & GS & $\mathrm{U}$ & Liénou et al., 2005 & 1 \\
\hline 87 & Cameroon & Nyong & Mbalmayo & 3.5123 & 11.5015 & $\mathrm{~A}$ & 13555 & 5.2 & $1994-1996$ & 3 & GS & $\mathrm{U}$ & Liénou et al., 2005 & 1 \\
\hline 88 & Cameroon & Ntem & Ngoazik & 2.2922 & 11.3345 & $\mathrm{~B}$ & 18100 & 10.6 & $1981-1983$ & 3 & GS & $\mathrm{U}$ & Liénou et al., 2005 & 1 \\
\hline 89 & Cameroon & Ngoko & Mouloundou & 2.0391 & 15.2085 & $\mathrm{~B}$ & 67075 & 11.5 & $1989-1992$ & 4 & GS & $\mathrm{U}$ & Liénou et al., 2005 & 1 \\
\hline 90 & Cameroon & Logone & Kousséri & 12.0809 & 15.0356 & $\mathrm{~B}$ & 85000 & 15 & $1970-1974$ & 5 & GS & $\mathrm{U}$ & Liénou et al., 2005 & 0 \\
\hline 91 & Cameroon & Mayo Tsanaga & Douar & 10.7830 & 13.8000 & A & 575 & 330 & 1977 & 1 & GS & $\mathrm{U}$ & Lienou, 2007 & 0 \\
\hline 92 & Cameroon & Metchum & Gouri & 6.2800 & 10.0300 & $\mathrm{~B}$ & 2116 & 118 & HY 1987/1988 & 1 & GS & A & Lienou, 2007 & 1 \\
\hline
\end{tabular}




\begin{tabular}{|l|c|c|c|c|c|c|c|c|c|c|c|c|c|}
\hline ID & Country & $\begin{array}{c}\text { River/Catchment } \\
\text { Name }\end{array}$ & $\begin{array}{c}\text { Measuring } \\
\text { location }\end{array}$ & Lat $\left(^{\circ}\right)$ & Lon $\left(^{\circ}\right)$ & $\begin{array}{c}\text { Coord. } \\
\text { Quality }\end{array}$ & A $\left(\mathbf{k m}^{2}\right)$ & $\begin{array}{c}\text { SY } \\
\left(\mathbf{t} / \mathrm{km}^{2} / \mathbf{y}\right)\end{array}$ & MP & $\begin{array}{c}\text { MP } \\
\text { length } \\
(\mathbf{y})\end{array}$ & $\begin{array}{c}\text { Type } \\
\text { Quality }\end{array}$ & $\begin{array}{c}\text { Data } \\
\text { Reference }\end{array}$ \\
\hline
\end{tabular}

\begin{tabular}{|c|c|c|c|c|c|c|c|c|c|c|c|c|c|c|}
\hline 94 & Cameroon & Boumba & Biwala & 3.2160 & 14.9160 & $\mathrm{~A}$ & 10310 & 10.8 & $1989-1992$ & 4 & GS & $\mathrm{U}$ & Lienou, 2007 & 1 \\
\hline 95 & Cameroon & Risso & subcatchment S3 & 7.8639 & 14.7008 & $\mathrm{C}$ & 33 & 17 & 1967 & 1 & GS & A & $\begin{array}{c}\text { Lienou, 2007; Nouvelot, } \\
1969\end{array}$ & 0 \\
\hline 96 & Cameroon & Nyong & near outlet & 3.2454 & 9.9060 & $\mathrm{~B}$ & 28000 & 3.6 & N.A. & N.A. & GS & $\mathrm{U}$ & $\begin{array}{l}\text { Milliman and Fansworth, } \\
2011\end{array}$ & 1 \\
\hline 97 & Cameroon & Sanaga & near outlet & 3.5692 & 9.6611 & $\mathrm{~B}$ & 130000 & 46.2 & N.A. & N.A. & GS & $\mathrm{U}$ & $\begin{array}{l}\text { Milliman and Fansworth, } \\
2011\end{array}$ & 1 \\
\hline 98 & Cameroon & Sanaga & Kiénké à Kribi & 2.9386 & 9.9064 & A & 1435 & 19.6 & $2002-2003$ & 2 & GS & $\mathrm{B}$ & $\begin{array}{l}\text { Ndam Ngoupayou et al., } \\
2007\end{array}$ & 1 \\
\hline 99 & Cameroon & Sanaga & Mungo Mundame & 4.5648 & 9.5357 & A & 2420 & 17 & $2002-2003$ & 2 & GS & B & $\begin{array}{l}\text { Ndam Ngoupayou et al., } \\
2007\end{array}$ & 1 \\
\hline 100 & Cameroon & Sanaga & Lom Bétaré Oya & 5.6229 & 14.0793 & $\mathrm{~B}$ & 11100 & 33.3 & $2002-2003$ & 2 & GS & B & $\begin{array}{l}\text { Ndam Ngoupayou et al., } \\
2007\end{array}$ & 1 \\
\hline 101 & Cameroon & Sanaga & Nachtigal & 4.3507 & 11.6301 & B & 77000 & 28 & $1967-1968$ & 2 & GS & $\mathrm{U}$ & $\begin{array}{l}\text { Olivry, 1977; Liénou et } \\
\text { al., 2005 }\end{array}$ & 1 \\
\hline 102 & Cameroon & Mayo Tsanaga & Bogo & 10.7350 & 14.5957 & A & 1535 & 188 & \begin{tabular}{|}
$1968 ; 1969 ; 1973 ; 198$ \\
$5-1986 ; 2002-2004$
\end{tabular} & 8 & GS & $\mathrm{U}$ & $\begin{array}{l}\text { Olivry, 1977; Liénou et } \\
\text { al., } 2009\end{array}$ & 1 \\
\hline 103 & Cameroon & Mbam & Goura & 12.3379 & 14.5558 & $\mathrm{C}$ & 42300 & 85.9 & $\begin{array}{c}1970-1974 ; 1994- \\
1996 ; 2005-2006\end{array}$ & 10 & GS & $\mathrm{U}$ & $\begin{array}{l}\text { Olivry, 1977; Ndam } \\
\text { Ngoupayou et al., } 2007\end{array}$ & 0 \\
\hline 104 & Cape Verde & Ribeira Brava & near Ribeira Brava & 16.6153 & -24.2966 & $\mathrm{C}$ & 6.7 & 4300 & $1978-1983$ & 6 & GS & $\mathrm{B}$ & Olivry et al., 1989 & 0 \\
\hline 105 & Cape Verde & Ribeira Grande & $\begin{array}{c}\text { near Estancia de } \\
\text { Bras }\end{array}$ & 16.6631 & -24.3181 & $\mathrm{C}$ & 11 & 55 & $1978-1983$ & 6 & GS & $\mathrm{B}$ & Olivry et al., 1989 & 0 \\
\hline 106 & Cape Verde & Ribeira Seca & Grande & 15.0493 & -23.5814 & $\mathrm{C}$ & 1.9 & 157 & $2004-2009$ & 6 & GS & B & Tavares, 2010 & 0 \\
\hline 107 & Cape Verde & Ribeira Seca & Godim & 15.0493 & -23.5602 & $\mathrm{C}$ & 2.0 & 10.1 & $2004-2009$ & 6 & GS & $\mathrm{B}$ & Tavares, 2010 & 0 \\
\hline 108 & Cape Verde & Ribeira Seca & Longueira & 15.0535 & -23.6049 & $\mathrm{C}$ & 4.2 & 4266.5 & $2004-2009$ & 6 & GS & $\mathrm{B}$ & Tavares, 2010 & 0 \\
\hline 109 & $\begin{array}{c}\text { Central } \\
\text { African Rep. }\end{array}$ & Mpoko & Nzongo & 4.1999 & 18.0300 & $\mathrm{C}$ & 23900 & 7.7 & $\begin{array}{c}\text { Nov } 1991 \text { - Nov } \\
1994\end{array}$ & 3 & GS & $\mathrm{C}$ & Coynel et al., 2005 & 0 \\
\hline 110 & $\begin{array}{c}\text { Central } \\
\text { African Rep. }\end{array}$ & Oubangui & Bangui & 4.3547 & 18.5853 & B & 489000 & 5.1 & $\begin{array}{c}\text { Nov } 1990 \text { - Sept } \\
1996\end{array}$ & 5 & GS & $\mathrm{C}$ & Coynel et al., 2005 & 1 \\
\hline 111 & $\begin{array}{c}\text { Central } \\
\text { African Rep. }\end{array}$ & Ubangi & Mongoumba & 3.6365 & 18.6015 & B & 553900 & 4.3 & 1993 & 1 & GS & $\mathrm{C}$ & Laraque et al., 2009 & 1 \\
\hline 112 & $\begin{array}{c}\text { Central } \\
\text { African Rep. }\end{array}$ & Ouham & Batangafo & 7.3090 & 18.2859 & B & 44700 & 9.3 & $1969-1970$ & 2 & GS & $\mathrm{U}$ & Liénou et al., 2005 & 1 \\
\hline 113 & $\begin{array}{c}\text { Central } \\
\text { African Rep. }\end{array}$ & Bangoran & near Bangoran & 8.7499 & 19.2939 & B & 2590 & 4.4 & N.A. & N.A. & GS & $\mathrm{U}$ & Walling, 1984 & 1 \\
\hline
\end{tabular}




\begin{tabular}{|c|c|c|c|c|c|c|c|c|c|c|c|c|c|c|}
\hline ID & Country & $\begin{array}{c}\text { River/Catchment } \\
\text { Name }\end{array}$ & $\begin{array}{l}\text { Measuring } \\
\text { location }\end{array}$ & Lat $\left(^{\circ}\right)$ & Lon $\left(^{\circ}\right)$ & $\begin{array}{l}\text { Coord. } \\
\text { Quality }\end{array}$ & $\mathbf{A}\left(\mathbf{k m}^{2}\right)$ & $\begin{array}{c}\mathrm{SY} \\
\left(\mathrm{t} / \mathbf{k m}^{2} / \mathbf{y}\right)\end{array}$ & MP & $\begin{array}{c}\text { MP } \\
\text { length } \\
(\mathbf{y})\end{array}$ & Type & $\begin{array}{l}\text { Data } \\
\text { Quality }\end{array}$ & Reference & GIS \\
\hline 114 & $\begin{array}{c}\text { Central } \\
\text { African Rep. }\end{array}$ & Gribingui & $\begin{array}{c}\text { near Kaga } \\
\text { Bandora }\end{array}$ & 6.9954 & 19.1830 & $\mathrm{~B}$ & 5680 & 5 & N.A. & N.A. & GS & $\mathrm{U}$ & Walling, 1984 & 1 \\
\hline 115 & $\begin{array}{c}\text { Central } \\
\text { African Rep. }\end{array}$ & Fafa & near Bouca & 6.4977 & 18.2681 & $\mathrm{~B}$ & 6750 & 3.1 & N.A. & N.A. & GS & $\mathrm{U}$ & Walling, 1984 & 1 \\
\hline 116 & Chad & Pende & Doba & 8.6593 & 16.8505 & $\mathrm{C}$ & 14300 & 25.4 & $\begin{array}{c}\text { HY 1969/1970 - HY } \\
1970 / 1971 \\
\end{array}$ & 2 & GS & $\mathrm{B}$ & Carré, 1972 & 0 \\
\hline 117 & Chad & Logone & Moundou & 8.5598 & 16.0870 & $\mathrm{~B}$ & 33970 & 65 & $\begin{array}{c}\text { HY 1969/1970 - HY } \\
1970 / 1971 \\
\end{array}$ & 2 & GS & $\mathrm{B}$ & Carré, 1972 & 1 \\
\hline 118 & Chad & Ouham & Manda & 9.1888 & 18.2043 & $\mathrm{~B}$ & 79600 & 9.7 & $\begin{array}{c}\text { HY 1968/1969 - HY } \\
1970 / 1971\end{array}$ & 3 & GS & $\mathrm{B}$ & Carré, 1972 & 1 \\
\hline 119 & Chad & Logone & Fort Foureau & 12.0820 & 15.0355 & B & 85000 & 15.2 & $\begin{array}{c}\text { HY 1969/1970 - HY } \\
1970 / 1971\end{array}$ & 2 & GS & $\mathrm{B}$ & Carré, 1972 & 0 \\
\hline 120 & Chad & Chari & Fort-Archambault & 9.1506 & 18.3940 & $\mathrm{~B}$ & 193000 & 1.2 & $\begin{array}{c}\text { HY 1968/1969 - HY } \\
1970 / 1971\end{array}$ & 3 & GS & $\mathrm{B}$ & Carré, 1972 & 1 \\
\hline 121 & Chad & Chari & Chagoua & 12.0876 & 15.0901 & $\mathrm{~B}$ & 515000 & 2.5 & $\begin{array}{c}\text { HY 1969/1970 - HY } \\
1970 / 1971\end{array}$ & 2 & GS & $\mathrm{B}$ & Carré, 1972 & 1 \\
\hline 122 & Chad & Ardéba & Am Timan & 11.0405 & 20.2937 & $\mathrm{~B}$ & 80000 & 9 & N.A. & N.A. & GS & $\mathrm{U}$ & $\begin{array}{c}\text { Dedkov and Mozzherin, } \\
1984\end{array}$ & 0 \\
\hline 123 & Chad & Logone & Lai & 9.4010 & 16.2876 & $\mathrm{~B}$ & 86000 & 50 & N.A. & N.A. & GS & $\mathrm{U}$ & $\begin{array}{c}\text { Dedkov and Mozzherin, } \\
1984\end{array}$ & 1 \\
\hline 124 & Chad & Logone & Laï & 9.3982 & 16.2883 & $\mathrm{~B}$ & 56700 & 39 & $1969-1975$ & 7 & GS & $\mathrm{U}$ & Liénou et al., 2005 & 1 \\
\hline 125 & Chad & Logone & Bongor & 10.2682 & 15.3678 & $\mathrm{~B}$ & 71100 & 34 & $1969-1976$ & 8 & GS & $\mathrm{U}$ & Liénou et al., 2005 & 1 \\
\hline 126 & Congo DR & Kavimvira & $\begin{array}{c}\text { outlet in lake } \\
\text { Tanganyika }\end{array}$ & -3.3546 & 29.1545 & A & 42 & 9.1 & $1999-2000$ & 1 & GS & $\mathrm{C}$ & Bombi et al., 2000 & 1 \\
\hline 127 & Congo DR & Kalimabenge & $\begin{array}{c}\text { outlet in lake } \\
\text { Tanganyika }\end{array}$ & -3.4114 & 29.1344 & A & 89 & 70.6 & $1999-2000$ & 1 & GS & $\mathrm{C}$ & Bombi et al., 2000 & 1 \\
\hline 128 & Congo DR & Mulongwe & $\begin{array}{c}\text { outlet in lake } \\
\text { Tanganyika }\end{array}$ & -3.3769 & 29.1436 & A & 113 & 2.4 & $1999-2000$ & 1 & GS & $\mathrm{C}$ & Bombi et al., 2000 & 1 \\
\hline 129 & Congo DR & Kasaï & Mushie & -3.0357 & 16.9094 & $\mathrm{~B}$ & 870000 & 8.9 & 1993 & 1 & GS & $\mathrm{C}$ & Laraque et al., 2009 & 1 \\
\hline 130 & Congo DR & Upper Kafubu & Sambwa & -11.8006 & 27.6571 & A & 1540 & 4.7 & $1979-1984$ & 5 & GS & $\mathrm{C}$ & $\begin{array}{l}\text { Lootens and Kishimbi, } \\
1986\end{array}$ & 1 \\
\hline 131 & Congo DR & Lubwe & Biayi & -11.6428 & 27.4626 & A & 8.5 & 12.7 & HY 1983/1984 & 1 & GS & B & $\begin{array}{c}\text { Lootens and Lumbu, } \\
1986\end{array}$ & 1 \\
\hline 132 & Congo DR & Congo & near outlet & -6.0247 & 12.4416 & $\mathrm{~B}$ & 3800000 & 11.3 & N.A. & N.A. & GS & $\mathrm{U}$ & $\begin{array}{l}\text { Milliman and Fansworth, } \\
2011\end{array}$ & 1 \\
\hline 133 & $\begin{array}{l}\text { Congo } \\
\text { Republic }\end{array}$ & Likouala Mossaka & Makoua & 0.0050 & 15.6120 & $\mathrm{~B}$ & 14100 & 5.2 & 1993 & 1 & GS & $\mathrm{C}$ & Laraque et al., 2009 & 1 \\
\hline 134 & $\begin{array}{l}\text { Congo } \\
\text { Republic }\end{array}$ & $\begin{array}{l}\text { Likouala Aux } \\
\text { Herbes }\end{array}$ & Botouali & -0.5319 & 17.3668 & $\mathrm{~B}$ & 24800 & 4.2 & 1993 & 1 & GS & $\mathrm{C}$ & Laraque et al., 2009 & 1 \\
\hline
\end{tabular}




\begin{tabular}{|l|c|c|c|c|c|c|c|c|c|c|c|c|c|}
\hline ID & Country & $\begin{array}{c}\text { River/Catchment } \\
\text { Name }\end{array}$ & $\begin{array}{c}\text { Measuring } \\
\text { location }\end{array}$ & Lat $\left(^{\circ}\right)$ & Lon $\left(^{\circ}\right)$ & $\begin{array}{c}\text { Coord. } \\
\text { Quality }\end{array}$ & A $\left(\mathbf{k m}^{2}\right)$ & $\begin{array}{c}\text { SY } \\
\left(\mathbf{t} / \mathbf{k m}^{2} / \mathbf{y}\right)\end{array}$ & MP & $\begin{array}{c}\text { MP } \\
\text { length } \\
(\mathbf{y})\end{array}$ & $\begin{array}{c}\text { Type } \\
\text { Quality }\end{array}$ & $\begin{array}{c}\text { ata } \\
\text { Reference }\end{array}$ \\
\hline
\end{tabular}

\begin{tabular}{|c|c|c|c|c|c|c|c|c|c|c|c|c|c|c|}
\hline 135 & $\begin{array}{l}\text { Congo } \\
\text { Republic }\end{array}$ & Sangha & Ouesso & 1.6166 & 16.0624 & B & 158300 & 9.2 & 1993 & 1 & GS & C & Laraque et al., 2009 & 1 \\
\hline 136 & $\begin{array}{c}\text { Congo } \\
\text { Republic }\end{array}$ & Lefini & Mbouambé & -2.9165 & 15.6337 & $\mathrm{~B}$ & 13500 & 9.4 & $1987-1991$ & 5 & GS & $\mathrm{U}$ & Liénou et al., 2005 & 1 \\
\hline 137 & $\begin{array}{c}\text { Congo } \\
\text { Republic }\end{array}$ & Alima & Tchikapika & -1.2668 & 16.1779 & $\mathrm{~B}$ & 20070 & 6 & $1987-1991$ & 5 & GS & $\mathrm{U}$ & Liénou et al., 2005 & 1 \\
\hline 138 & $\begin{array}{c}\text { Congo } \\
\text { Republic }\end{array}$ & Congo & Brazzaville & -4.2871 & 15.2907 & $\mathrm{~B}$ & 3500000 & 8.7 & $1987-1991$ & 5 & GS & $\mathrm{U}$ & Liénou et al., 2005 & 1 \\
\hline 139 & Egypt & Nile & High Aswan & 23.8944 & 32.8667 & $\mathrm{~B}$ & 2960000 & 41.1 & N.A. & N.A. & $\mathrm{R}$ & $\mathrm{U}$ & Shahin, 2003 & 1 \\
\hline 140 & Eritrea & Ghinda & near Imbatikala & 15.4484 & 39.0896 & $\mathrm{~B}$ & 174 & 2241.4 & N.A. & 17 & $\mathrm{R}$ & $\mathrm{U}$ & Nyssen et al., 2004 & 1 \\
\hline 141 & Ethiopia & Koga & near Merawi & 11.3667 & 37.0500 & $\mathrm{~A}$ & 244 & 410 & $1983-1990 ; 1992$ & 8 & GS & $\mathrm{C}$ & BCEOM, 1997 & 1 \\
\hline 142 & Ethiopia & Fettam & Tilili & 10.8500 & 37.0167 & A & 282 & 657 & $\begin{array}{c}1980-1989 ; 1991- \\
1992\end{array}$ & 12 & GS & $\mathrm{C}$ & BCEOM, 1997 & 1 \\
\hline 143 & Ethiopia & Neshi & near Shambo & 9.5500 & 37.3667 & $\mathrm{~B}$ & 322 & 375 & $1980-1991$ & 12 & GS & $\mathrm{C}$ & BCEOM, 1997 & 0 \\
\hline 144 & Ethiopia & Chemoga & Debre Markos & 10.3000 & 37.7333 & $\mathrm{~B}$ & 364 & 444 & $1980-1992$ & 13 & GS & $\mathrm{C}$ & BCEOM, 1997 & 0 \\
\hline 145 & Ethiopia & Megech & Azezo & 12.4833 & 37.4500 & $\mathrm{~A}$ & 462 & 569 & $1980-1992$ & 13 & GS & $\mathrm{C}$ & BCEOM, 1997 & 1 \\
\hline 146 & Ethiopia & Muger & near Chancho & 9.3000 & 38.7333 & A & 489 & 78 & $\begin{array}{c}1980-1984 ; 1986- \\
1992 \\
\end{array}$ & 12 & GS & C & BCEOM, 1997 & 1 \\
\hline 147 & Ethiopia & Guder & Guder & 8.9500 & 37.7500 & B & 524 & 90 & $\begin{array}{c}1980-1981 ; 1983- \\
1992 \\
\end{array}$ & 12 & GS & $\mathrm{C}$ & BCEOM, 1997 & 0 \\
\hline 148 & Ethiopia & Dura & near Metekel & 10.7833 & 35.5500 & $\mathrm{~B}$ & 539 & 717 & $\begin{array}{c}1980-1981 ; 1983- \\
1985 ; 1987-1992\end{array}$ & 11 & GS & $\mathrm{C}$ & BCEOM, 1997 & 0 \\
\hline 149 & Ethiopia & Upper Ribb & Debre Tabor & 11.8500 & 38.0000 & A & 844 & 56 & $\begin{array}{c}1982 \text { - 1986; } 1988 \text { - } \\
1990 \\
\end{array}$ & 8 & GS & $\mathrm{C}$ & BCEOM, 1997 & 0 \\
\hline 150 & Ethiopia & Birr & near Jiga & 10.6500 & 37.3833 & A & 975 & 2129 & $\begin{array}{c}1980 \text { - 1986; } 1988 \text { - } \\
1991 \\
\end{array}$ & 11 & GS & C & BCEOM, 1997 & 1 \\
\hline 151 & Ethiopia & Gumara & near Bahir Dar & 11.8333 & 37.6333 & $\mathrm{~A}$ & 1394 & 1390 & $1980-1992$ & 13 & GS & $\mathrm{C}$ & BCEOM, 1997 & 1 \\
\hline 152 & Ethiopia & Ribb & near Addis Zemen & 12.0000 & 37.7167 & $\mathrm{~A}$ & 1592 & 80 & $\begin{array}{c}1982 ; 1984 ; 1986- \\
1990 ; 1992\end{array}$ & 8 & GS & $\mathrm{C}$ & BCEOM, 1997 & 1 \\
\hline 153 & Ethiopia & Gilgel Abbay & near Merawi & 11.3667 & 37.0333 & $\mathrm{~A}$ & 1664 & 1695.3 & $1980-1992$ & 13 & GS & $\mathrm{C}$ & BCEOM, 1997 & 1 \\
\hline 154 & Ethiopia & Angar & near Gutin & 9.5500 & 36.6167 & $\mathrm{~A}$ & 1975 & 89 & $\begin{array}{c}1982-1983 ; 1987- \\
1992 \\
\end{array}$ & 8 & GS & $\mathrm{C}$ & BCEOM, 1997 & 0 \\
\hline 155 & Ethiopia & Dabana & near Abasina & 9.0333 & 36.0500 & $\mathrm{~A}$ & 2881 & 157 & $1980-1984$ & 5 & GS & $\mathrm{C}$ & BCEOM, 1997 & 1 \\
\hline 156 & Ethiopia & Beles & near Meketel & 11.2000 & 36.3333 & $\mathrm{~B}$ & 3431 & 456 & $1983-1990 ; 1992$ & 9 & GS & $\mathrm{C}$ & BCEOM, 1997 & 1 \\
\hline
\end{tabular}




\begin{tabular}{|c|c|c|c|c|c|c|c|c|c|c|c|c|c|c|}
\hline ID & Country & $\begin{array}{c}\text { River/Catchment } \\
\text { Name }\end{array}$ & $\begin{array}{l}\text { Measuring } \\
\text { location }\end{array}$ & Lat $\left(^{\circ}\right)$ & Lon $\left(^{\circ}\right)$ & $\begin{array}{l}\text { Coord. } \\
\text { Quality }\end{array}$ & $\mathbf{A}\left(\mathbf{k m}^{2}\right)$ & $\underset{\left(\mathbf{t} / \mathbf{k m}^{2} / \mathbf{y}\right)}{\mathbf{S Y}}$ & MP & $\begin{array}{c}\text { MP } \\
\text { length } \\
\text { (y) }\end{array}$ & Type & $\begin{array}{l}\text { Data } \\
\text { Quality }\end{array}$ & Reference & GIS \\
\hline & & & & & & & & & & & & & & \\
\hline 157 & Ethiopia & Angar & near Nekemte & 9.4333 & 36.4167 & A & 4674 & 150 & $1980-1985$ & 6 & GS & $\mathrm{C}$ & BCEOM, 1997 & 1 \\
\hline 158 & Ethiopia & Abbay & near Bahir Dar & 11.6000 & 37.4000 & A & 15321 & 68 & $\begin{array}{c}1980-1981 ; 1983- \\
1990 ; 1992\end{array}$ & 11 & GS & $\mathrm{C}$ & BCEOM, 1997 & 1 \\
\hline 159 & Ethiopia & Abbay & Kessie & 11.0667 & 38.1833 & A & 65784 & 751 & $\begin{array}{c}1980 ; 1982 \text { - 1990; } \\
1992\end{array}$ & 11 & GS & $\mathrm{C}$ & BCEOM, 1997 & 0 \\
\hline 161 & Ethiopia & Awash & Kolka & 8.4690 & 39.1513 & B & 10115 & 1468 & $1959-1973$ & 15 & $\mathrm{R}$ & $\mathrm{U}$ & FAO, 2008 & 1 \\
\hline 162 & Ethiopia & Andit Tid & near Welde $\mathrm{Ab}$ & 9.8000 & 39.7167 & A & 4.8 & 520 & $1989-1996$ & 8 & GS & B & Guzman et al., 2012 & 0 \\
\hline 163 & Ethiopia & & Adihilo & 13.4439 & 39.5675 & A & 0.72 & 950 & N.A. & 5 & $\mathrm{R}$ & A & Haregeweyn et al., 2008 & 1 \\
\hline 164 & Ethiopia & & Endazoey & 13.4760 & 39.6765 & $\mathrm{~B}$ & 1.4 & 695 & N.A. & 5 & $\mathrm{R}$ & $\mathrm{A}$ & Haregeweyn et al., 2008 & 0 \\
\hline 165 & Ethiopia & & Mejae & 13.1945 & 39.5079 & A & 2.6 & 617 & N.A. & 5 & $\mathrm{R}$ & A & Haregeweyn et al., 2008 & 1 \\
\hline 166 & Ethiopia & & Adiakor & 13.4083 & 39.5735 & A & 2.9 & 397 & N.A. & 5 & $\mathrm{R}$ & $\mathrm{A}$ & Haregeweyn et al., 2008 & 1 \\
\hline 167 & Ethiopia & & Gereb Segen & 13.2570 & 39.4949 & A & 4.4 & 1182 & N.A. & 3 & $\mathrm{R}$ & A & Haregeweyn et al., 2008 & 1 \\
\hline 169 & Ethiopia & & Gereb Shegel & 13.5898 & 39.4549 & A & 8.6 & 487 & N.A. & 5 & $\mathrm{R}$ & A & Haregeweyn et al., 2008 & 1 \\
\hline 170 & Ethiopia & & Maideli & 13.2208 & 39.5268 & A & 11 & 1429 & N.A. & 5 & $\mathrm{R}$ & A & Haregeweyn et al., 2008 & 1 \\
\hline 171 & Ethiopia & & Gindae & 13.7715 & 39.3389 & A & 12 & 1216 & N.A. & 5 & $\mathrm{R}$ & A & Haregeweyn et al., 2008 & 1 \\
\hline 172 & Ethiopia & & Adikenafiz & 13.2580 & 39.4083 & A & 14 & 1350 & N.A. & 6 & $\mathrm{R}$ & A & Haregeweyn et al., 2008 & 1 \\
\hline 173 & Ethiopia & & Gum Selasse & 13.2422 & 39.5456 & A & 24 & 736 & N.A. & 7 & $\mathrm{R}$ & A & Haregeweyn et al., 2008 & 1 \\
\hline 174 & Ethiopia & Angereb & Angereb reservoir & 12.6132 & 37.4865 & A & 68 & 2927 & $1997-2007$ & 20 & $\mathrm{R}$ & A & Haregeweyn et al., 2012 & 1 \\
\hline 175 & Ethiopia & Unta & south of Dedo & 7.4796 & 36.8802 & B & 113 & 6264.5 & $2010-2011$ & 2 & GS & $\mathrm{B}$ & Kissi et al., 2013 & 0 \\
\hline 176 & Ethiopia & Nada Kallo & $\begin{array}{c}\text { near outlet in } \\
\text { Gilgel Gibe } \\
\text { reservoir }\end{array}$ & 7.7570 & 37.3322 & A & 148 & 1176.1 & $2010-2011$ & 2 & GS & B & Kissi et al., 2013 & 1 \\
\hline 177 & Ethiopia & Nada Guda & $\begin{array}{c}\text { near outlet in } \\
\text { Gilgel Gibe } \\
\text { reservoir }\end{array}$ & 7.6881 & 37.2324 & A & 237 & 392.5 & $2010-2011$ & 2 & GS & B & Kissi et al., 2013 & 1 \\
\hline 178 & Ethiopia & Bulbul & near Daraba & 7.7145 & 37.0868 & A & 507 & 675.5 & $2010-2011$ & 2 & GS & $\mathrm{B}$ & Kissi et al., 2013 & 1 \\
\hline 179 & Ethiopia & Nadie & $\begin{array}{l}\text { near outlet in } \\
\text { Gilgel Gibe } \\
\text { reservoir }\end{array}$ & 7.8670 & 37.2765 & A & 540 & 374.2 & $2010-2011$ & 2 & GS & B & Kissi et al., 2013 & 1 \\
\hline 180 & Ethiopia & Gilgel Gibe & $\begin{array}{c}\text { near outlet in } \\
\text { Gilgel Gibe } \\
\text { reservoir }\end{array}$ & 7.7577 & 37.1911 & A & 2738 & 279 & $2010-2011$ & 2 & GS & B & Kissi et al., 2013 & 1 \\
\hline
\end{tabular}




\begin{tabular}{|l|c|c|c|c|c|c|c|c|c|c|c|c|c|}
\hline ID & Country & $\begin{array}{c}\text { River/Catchment } \\
\text { Name }\end{array}$ & $\begin{array}{c}\text { Measuring } \\
\text { location }\end{array}$ & Lat $\left(^{\circ}\right)$ & Lon $\left(^{\circ}\right)$ & $\begin{array}{c}\text { Coord. } \\
\text { Quality }\end{array}$ & A $\left(\mathbf{k m}^{2}\right)$ & $\begin{array}{c}\text { SY } \\
\left(\mathbf{t} / \mathrm{km}^{2} / \mathbf{y}\right)\end{array}$ & MP & $\begin{array}{c}\text { MP } \\
\text { length } \\
(\mathbf{y})\end{array}$ & $\begin{array}{c}\text { Type } \\
\text { Quality }\end{array}$ & $\begin{array}{c}\text { Data } \\
\text { Reference }\end{array}$ \\
\hline
\end{tabular}

\begin{tabular}{|c|c|c|c|c|c|c|c|c|c|c|c|c|c|c|}
\hline 182 & Ethiopia & Debaba & Shala & 7.4000 & 38.6333 & $\mathrm{~B}$ & 470 & 214 & 2008 & 1 & GS & $\mathrm{C}$ & Meshesha et al., 2011 & 0 \\
\hline 183 & Ethiopia & Blate & Shala & 7.6167 & 38.4500 & B & 733 & 474 & 2008 & 1 & GS & $\mathrm{C}$ & Meshesha et al., 2011 & 0 \\
\hline 184 & Ethiopia & Melka & Shala & 7.4000 & 38.4167 & $\mathrm{~B}$ & 746 & 326 & 2008 & 1 & GS & $\mathrm{C}$ & Meshesha et al., 2011 & 0 \\
\hline 185 & Ethiopia & Meki & Ziway & 8.1167 & 38.8667 & $\mathrm{~B}$ & 1423 & 611 & 2008 & 1 & GS & $\mathrm{C}$ & Meshesha et al., 2011 & 0 \\
\hline 187 & Ethiopia & Midmar & near Axum & 14.2090 & 38.9165 & $\mathrm{~B}$ & 6.7 & 2100 & N.A. & N.A. & $\mathrm{R}$ & $\mathrm{U}$ & Nyssen et al., 2004 & 0 \\
\hline 188 & Ethiopia & Jinbar & near Ambaras & 13.2455 & 38.0868 & $\mathrm{~A}$ & 30 & 2200 & N.A. & 1 & GS & $\mathrm{U}$ & Nyssen et al., 2004 & 1 \\
\hline 189 & Ethiopia & Mesanu & near Ki'en & 13.4984 & 39.5586 & B & 150 & 1680 & N.A. & N.A. & GS & B & Nyssen et al., 2004 & 1 \\
\hline 190 & Ethiopia & & Borkenna III dam & 11.8045 & 39.7925 & $\mathrm{~B}$ & 465 & 8387.1 & N.A. & 2 & $\mathrm{R}$ & $\mathrm{U}$ & Nyssen et al., 2004 & 0 \\
\hline 191 & Ethiopia & Meki & Meki town bridge & 8.1508 & 38.8225 & B & 1780 & 133 & N.A. & 5 & GS & $\mathrm{U}$ & Nyssen et al., 2004 & 0 \\
\hline 192 & Ethiopia & Wabi Shebelle & Malka-Wakana & 7.1772 & 39.4326 & $\mathrm{~B}$ & 5290 & 21 & N.A. & N.A. & GS & $\mathrm{U}$ & Nyssen et al., 2004 & 1 \\
\hline 193 & Ethiopia & Daketa & Hamero & 7.9695 & 41.9399 & $\mathrm{~B}$ & 14200 & 350 & N.A. & N.A. & GS & $\mathrm{U}$ & Nyssen et al., 2004 & 0 \\
\hline 194 & Ethiopia & Fafen & Kebri-Dahar & 6.7406 & 44.2860 & $\mathrm{~B}$ & 25600 & 98 & N.A. & N.A. & GS & $\mathrm{U}$ & Nyssen et al., 2004 & 1 \\
\hline 195 & Ethiopia & Wabi Shebelle & Hamero-Hedad & 8.2142 & 42.0911 & B & 64490 & 124 & N.A. & N.A. & GS & $\mathrm{U}$ & Nyssen et al., 2004 & 1 \\
\hline 196 & Ethiopia & Wabi Shebelle & Gode & 5.9255 & 43.5473 & $\mathrm{~B}$ & 127300 & 118 & N.A. & N.A. & GS & $\mathrm{U}$ & Nyssen et al., 2004 & 1 \\
\hline 197 & Ethiopia & May Zegzeg & Hagere Selam & 13.6393 & 39.1989 & $\mathrm{~B}$ & 1.9 & 520 & $2000 ; 2006$ & 2 & GS & $\mathrm{B}$ & Nyssen et al., 2009 & 0 \\
\hline 198 & Ethiopia & Minchet & Anjeni & 10.6785 & 37.5305 & A & 1.1 & 2456.2 & $1985-1993$ & 9 & GS & $\mathrm{U}$ & SCRP, 2000b & 1 \\
\hline 200 & Ethiopia & Goppo & Sidamo & 6.9322 & 37.6378 & $\mathrm{~A}$ & 0.94 & 62.3 & $1981-1992$ & 12 & GS & $\mathrm{U}$ & SCRP, 2000c & 1 \\
\hline 201 & Ethiopia & Maybar & South Wello & 10.9960 & 39.6577 & A & 1.1 & 1326.6 & $1982-1989 ; 1992$ & 9 & GS & $\mathrm{U}$ & SCRP, 2000e & 1 \\
\hline 202 & Ethiopia & Dizi & Illulabor & 8.3667 & 35.6000 & B & 6.7 & 0.2 & $1989-1992$ & 4 & GS & $\mathrm{U}$ & SCRP, 2000f & 0 \\
\hline 203 & Ethiopia & Hunde Lafto & Harerge & 9.1201 & 40.9944 & A & 2.4 & 4296.6 & $1983-1991$ & 9 & GS & $\mathrm{U}$ & SCRP, $2000 \mathrm{~g}$ & 1 \\
\hline 204 & Ethiopia & & Koka & 8.3925 & 39.0859 & $\mathrm{~A}$ & 4050 & 4749 & N.A. & N.A. & $\mathrm{R}$ & $\mathrm{U}$ & Shahin, 2003 & 0 \\
\hline 205 & Ethiopia & Teghane & near Mek'ele & 13.5300 & 39.4500 & $\mathrm{C}$ & 7.0 & 345 & $1996-2003$ & 6 & $\mathrm{R}$ & B & $\begin{array}{l}\text { Tamene et al., 2006; } \\
\text { Balthazar et al., } 2012\end{array}$ & 0 \\
\hline 206 & Ethiopia & Laelaywukro & near Adi Kolen & 13.4800 & 39.3600 & $\mathrm{~B}$ & 9.9 & 649 & $1997-2003$ & 7 & $\mathrm{R}$ & $\mathrm{B}$ & $\begin{array}{c}\text { Tamene et al., } \\
\text { 2006Balthazar et al., } \\
2012 \\
\end{array}$ & 0 \\
\hline 207 & Ethiopia & Korir & near Gurare & 13.1500 & 39.2400 & $\mathrm{C}$ & 19 & 1058 & $1995-2003$ & 9 & $\mathrm{R}$ & $\mathrm{B}$ & $\begin{array}{c}\text { Tamene et al., } \\
\text { 2006Balthazar et al., } \\
2012\end{array}$ & 0 \\
\hline 208 & Ethiopia & Gerebmihiz & near Adeba & 13.1800 & 39.2800 & $\mathrm{C}$ & 20 & 3914 & $1997-2003$ & 7 & $\mathrm{R}$ & B & $\begin{array}{c}\text { Tamene et al., } \\
\text { 2006Balthazar et al., } \\
2012\end{array}$ & 0 \\
\hline
\end{tabular}




\begin{tabular}{|c|c|c|c|c|c|c|c|c|c|c|c|c|c|c|}
\hline ID & Country & $\begin{array}{c}\text { River/Catchment } \\
\text { Name }\end{array}$ & $\begin{array}{l}\text { Measuring } \\
\text { location }\end{array}$ & Lat $\left(^{\circ}\right)$ & Lon $\left(^{\circ}\right)$ & $\begin{array}{l}\text { Coord. } \\
\text { Quality }\end{array}$ & $\mathbf{A}\left(\mathbf{k m}^{2}\right)$ & $\begin{array}{c}\mathbf{S Y} \\
\left(\mathrm{t} / \mathbf{k m}^{2} / \mathbf{y}\right)\end{array}$ & MP & $\begin{array}{c}\text { MP } \\
\text { length } \\
(\mathbf{y})\end{array}$ & Type & $\begin{array}{l}\text { Data } \\
\text { Quality }\end{array}$ & Reference & GIS \\
\hline 209 & Ethiopia & Endaselassie & outlet in Geba & 13.4920 & 39.2085 & $\mathrm{~A}$ & 121 & 733 & $2006-2007$ & 2 & GS & B & $\begin{array}{l}\text { Vanmaercke et al., 2010; } \\
\text { Zenebe et al., } 2013\end{array}$ & 1 \\
\hline 210 & Ethiopia & Upper Tankwa & Abiy Addi & 13.6165 & 38.9991 & $\mathrm{~A}$ & 130 & 2272 & $2006-2007$ & 2 & GS & B & $\begin{array}{l}\text { Vanmaercke et al., 2010; } \\
\text { Zenebe et al., } 2013\end{array}$ & 1 \\
\hline 211 & Ethiopia & Lower Tankwa & outlet in Geba & 13.5378 & 38.8926 & A & 216 & 3627 & $2006-2007$ & 2 & GS & B & $\begin{array}{l}\text { Vanmaercke et al., 2010; } \\
\text { Zenebe et al., } 2013\end{array}$ & 1 \\
\hline 212 & Ethiopia & Ilala & outlet in Geba & 13.5837 & 39.3896 & A & 341 & 878 & $2004-2007$ & 4 & GS & B & $\begin{array}{l}\text { Vanmaercke et al., 2010; } \\
\text { Zenebe et al., } 2013\end{array}$ & 1 \\
\hline 213 & Ethiopia & May Gabat & outlet in Geba & 13.4702 & 39.2975 & A & 652 & 752 & $2006-2007$ & 2 & GS & B & $\begin{array}{l}\text { Vanmaercke et al., 2010; } \\
\text { Zenebe et al., } 2013\end{array}$ & 1 \\
\hline 214 & Ethiopia & Agula & outlet in Geba & 13.6252 & 39.4078 & A & 692 & 3784 & $2005-2007$ & 3 & GS & B & $\begin{array}{l}\text { Vanmaercke et al., 2010; } \\
\text { Zenebe et al., } 2013\end{array}$ & 1 \\
\hline 215 & Ethiopia & Genfel & near Diyadib & 13.6477 & 39.4184 & A & 733 & 497 & 2006 & 1 & GS & B & $\begin{array}{c}\text { Vanmaercke et al., 2010; } \\
\text { Zenebe et al., } 2013\end{array}$ & 1 \\
\hline 216 & Ethiopia & Suluh & near Diyadib & 13.6494 & 39.4140 & A & 969 & 890 & 2004; 2006; 2007 & 3 & GS & $\mathrm{B}$ & $\begin{array}{c}\text { Vanmaercke et al., 2010; } \\
\text { Zenebe et al., } 2013\end{array}$ & 1 \\
\hline 217 & Ethiopia & Upper Geba & $\begin{array}{c}\text { roadbridge Mekele } \\
\text { - Hagere Selam }\end{array}$ & 13.5409 & 39.3565 & $\mathrm{~A}$ & 3035 & 1109 & $2006-2007$ & 2 & GS & $\mathrm{B}$ & $\begin{array}{l}\text { Vanmaercke et al., 2010; } \\
\text { Zenebe et al., } 2013\end{array}$ & 1 \\
\hline 218 & Ethiopia & Middle Geba & near Adi Buda & 13.5117 & 38.8951 & $\mathrm{~A}$ & 4592 & 1065 & 2007 & 1 & GS & B & $\begin{array}{c}\text { Vanmaercke et al., 2010; } \\
\text { Zenebe et al., } 2013\end{array}$ & 1 \\
\hline 219 & Gambia & Gambia & near outlet & 13.4209 & -16.5522 & B & 77000 & 2.6 & N.A. & N.A. & GS & $\mathrm{U}$ & $\begin{array}{l}\text { Milliman and Fansworth, } \\
2011 \\
\end{array}$ & 1 \\
\hline 220 & Ghana & & Dua & 10.9371 & -0.8149 & $\mathrm{C}$ & 0.35 & 10270 & $1997-2007$ & 10 & $\mathrm{R}$ & $\mathrm{A}$ & Adwubi et al., 2009 & 0 \\
\hline 221 & Ghana & & Kumpalgogo & 10.9959 & -0.3970 & $\mathrm{C}$ & 0.40 & 15699 & $1998-2007$ & 9 & $\mathrm{R}$ & $\mathrm{A}$ & Adwubi et al., 2009 & 0 \\
\hline 222 & Ghana & & Doba & 10.8902 & -1.0530 & $\mathrm{~B}$ & 0.70 & 1850 & $1998-2007$ & 9 & $\mathrm{R}$ & A & Adwubi et al., 2009 & 1 \\
\hline 223 & Ghana & & Zebilla & 10.9260 & -0.5225 & $\mathrm{~B}$ & 1.1 & 2668 & $1998-2007$ & 9 & $\mathrm{R}$ & $\mathrm{A}$ & Adwubi et al., 2009 & 1 \\
\hline 224 & Ghana & Birim & Bunso & 5.7644 & -1.0192 & $\mathrm{C}$ & 150 & 24.3 & 1991 & 1 & GS & $\mathrm{U}$ & $\begin{array}{l}\text { Akrasi and Ansa-Asare, } \\
2008\end{array}$ & 0 \\
\hline 225 & Ghana & Anum & Konongo & 6.6141 & -1.2156 & A & 681 & 17.9 & 1991 & 1 & GS & $\mathrm{U}$ & $\begin{array}{l}\text { Akrasi and Ansa-Asare, } \\
2008\end{array}$ & 1 \\
\hline 226 & Ghana & Oda & Anwia-Nkwanta & 5.9987 & -2.9628 & $\mathrm{C}$ & 1303 & 26.9 & 1991 & 1 & GS & $\mathrm{U}$ & $\begin{array}{l}\text { Akrasi and Ansa-Asare, } \\
2008\end{array}$ & 0 \\
\hline 227 & Ghana & Ofin & Mfensi & 6.7663 & -1.7783 & B & 1515 & 24.8 & 1991 & 1 & GS & $\mathrm{U}$ & $\begin{array}{c}\text { Akrasi and Ansa-Asare, } \\
2008\end{array}$ & 1 \\
\hline 228 & Ghana & Birim & Oda & 5.9319 & -0.9996 & A & 3248 & 40 & $1989-1991$ & 3 & GS & $\mathrm{U}$ & $\begin{array}{l}\text { Akrasi and Ansa-Asare, } \\
2008\end{array}$ & 1 \\
\hline 229 & Ghana & Ofin & Dunkwa & 5.1163 & -1.6169 & $\mathrm{C}$ & 8345 & 45.1 & $1989-1991$ & 3 & GS & $\mathrm{U}$ & $\begin{array}{l}\text { Akrasi and Ansa-Asare, } \\
2008\end{array}$ & 0 \\
\hline
\end{tabular}




\begin{tabular}{|c|c|c|c|c|c|c|c|c|c|c|c|c|c|c|}
\hline ID & Country & $\begin{array}{c}\text { River/Catchment } \\
\text { Name }\end{array}$ & $\begin{array}{l}\text { Measuring } \\
\text { location }\end{array}$ & Lat $\left(^{\circ}\right)$ & Lon $\left(^{\circ}\right)$ & $\begin{array}{l}\text { Coord. } \\
\text { Quality }\end{array}$ & $\mathbf{A}\left(\mathbf{k m}^{2}\right)$ & $\begin{array}{c}\text { SY } \\
\left(\mathbf{t} / \mathrm{km}^{2} / \mathbf{y}\right)\end{array}$ & MP & $\begin{array}{c}\text { MP } \\
\text { length } \\
(\mathbf{y})\end{array}$ & Type & $\begin{array}{l}\text { Data } \\
\text { Quality }\end{array}$ & Reference & GIS \\
\hline 230 & Ghana & Pra & Assin-Praso & 5.9325 & -1.3663 & B & 9793 & 32.6 & $1989-1991$ & 3 & GS & $\mathrm{U}$ & $\begin{array}{l}\text { Akrasi and Ansa-Asare, } \\
2008\end{array}$ & 1 \\
\hline 231 & Ghana & Pra & Twifu-Praso & 5.6034 & -1.5548 & B & 20767 & 44.1 & $1989-1991$ & 3 & GS & $\mathrm{U}$ & $\begin{array}{l}\text { Akrasi and Ansa-Asare, } \\
2008\end{array}$ & 1 \\
\hline 232 & Ghana & Pra & Beposo & 5.6014 & -2.0587 & B & 22818 & 46.9 & $1987-1991$ & 5 & GS & $\mathrm{U}$ & $\begin{array}{l}\text { Akrasi and Ansa-Asare, } \\
2008\end{array}$ & 1 \\
\hline 233 & Ghana & Afram & Aframso & 7.3251 & -1.3830 & $\mathrm{~B}$ & 308 & 14.8 & N.A. & N.A. & GS & $\mathrm{B}$ & Akrasi, 2005 & 0 \\
\hline 234 & Ghana & Pru & Pruso & 7.5410 & -1.4962 & $\mathrm{~B}$ & 1121 & 9.1 & N.A. & N.A. & GS & $\mathrm{B}$ & Akrasi, 2005 & 1 \\
\hline 235 & Ghana & Daka & Ekumdipe & 8.4034 & -0.2185 & $\mathrm{~B}$ & 6586 & 26.9 & N.A. & N.A. & GS & $\mathrm{B}$ & Akrasi, 2005 & 0 \\
\hline 236 & Ghana & Oti & Saboba & 9.6961 & 0.3483 & $\mathrm{~B}$ & 54890 & 46.6 & N.A. & N.A. & GS & $\mathrm{B}$ & Akrasi, 2005 & 1 \\
\hline 237 & Ghana & White Volta & Pwalugu & 10.5899 & -0.8356 & $\mathrm{~B}$ & 57397 & 21.7 & N.A. & N.A. & GS & $\mathrm{B}$ & Akrasi, 2005 & 1 \\
\hline 238 & Ghana & Black Volta & Lawra & 10.6576 & -2.8959 & $\mathrm{~B}$ & 90658 & 15.2 & N.A. & N.A. & GS & $\mathrm{B}$ & Akrasi, 2005 & 1 \\
\hline 239 & Ghana & White Volta & Nawuni & 9.6953 & -1.1048 & $\mathrm{~B}$ & 96957 & 22.9 & N.A. & N.A. & GS & $\mathrm{B}$ & Akrasi, 2005 & 0 \\
\hline 240 & Ghana & Black Volta & Bamboi & 8.1588 & -2.0347 & $\mathrm{~B}$ & 128759 & 25.7 & N.A. & N.A. & GS & $\mathrm{B}$ & Akrasi, 2005 & 1 \\
\hline 241 & Ghana & & Bugri & 10.7614 & -0.1352 & $\mathrm{~A}$ & 2.2 & 1828 & $1994-2007$ & 13 & $\mathrm{R}$ & $\mathrm{A}$ & Amegashie et al., 2011 & 1 \\
\hline 242 & Ghana & Ayensu & near outlet & 5.4987 & -0.3327 & B & 1700 & 88.2 & N.A. & N.A. & GS & $\mathrm{U}$ & $\begin{array}{l}\text { Milliman and Fansworth, } \\
2011\end{array}$ & 0 \\
\hline 243 & Ghana & Ankobra & near outlet & 4.8909 & -2.2770 & B & 6200 & 290.3 & N.A. & N.A. & GS & $\mathrm{U}$ & $\begin{array}{l}\text { Milliman and Fansworth, } \\
2011\end{array}$ & 0 \\
\hline 244 & Ghana & Pra & near outlet & 5.0372 & -1.6080 & B & 38000 & 63.2 & N.A. & N.A. & GS & $\mathrm{U}$ & $\begin{array}{l}\text { Milliman and Fansworth, } \\
2011\end{array}$ & 1 \\
\hline 245 & Ghana & Volta & near outlet & 5.7909 & 0.6579 & B & 400000 & 47.5 & N.A. & N.A. & GS & $\mathrm{U}$ & $\begin{array}{l}\text { Milliman and Fansworth, } \\
2011\end{array}$ & 1 \\
\hline 246 & Guinea & Milo & Kankan & 10.3673 & -9.2960 & $\mathrm{~A}$ & 9600 & 21.3 & $1987-1987$ & 1 & GS & $\mathrm{U}$ & Liénou et al., 2005 & 1 \\
\hline 247 & Guinea & Konkoure & near outlet & 9.8212 & -13.7655 & B & 16000 & 23.8 & N.A. & N.A. & GS & $\mathrm{U}$ & $\begin{array}{l}\text { Milliman and Fansworth, } \\
2011\end{array}$ & 1 \\
\hline 248 & Ivory Coast & Bandama & Ravineau & 5.9184 & -4.9124 & B & 0.02 & 6.1 & $1964-1967$ & 4 & $\begin{array}{l}\text { GS } \\
\text { (TL) }\end{array}$ & $\mathrm{C}$ & Mathieu, 1971 & 1 \\
\hline 249 & Ivory Coast & St. Pedro & near outlet & 4.7384 & -6.6083 & B & 3300 & 21.2 & N.A. & N.A. & GS & $\mathrm{U}$ & $\begin{array}{l}\text { Milliman and Fansworth, } \\
2011\end{array}$ & 1 \\
\hline 250 & Ivory Coast & Agneby & near outlet & 5.2803 & -4.3291 & B & 8900 & 168.5 & N.A. & N.A. & GS & $\mathrm{U}$ & $\begin{array}{l}\text { Milliman and Fansworth, } \\
2011\end{array}$ & 0 \\
\hline 251 & Ivory Coast & Tano & near outlet & 5.1162 & -2.8939 & B & 16000 & 21.9 & N.A. & N.A. & GS & $\mathrm{U}$ & $\begin{array}{l}\text { Milliman and Fansworth, } \\
2011\end{array}$ & 1 \\
\hline 252 & Ivory Coast & Comoe & near outlet & 5.1889 & -3.7110 & B & 78000 & 115.4 & N.A. & N.A. & GS & $\mathrm{U}$ & $\begin{array}{l}\text { Milliman and Fansworth, } \\
2011\end{array}$ & 1 \\
\hline 253 & Ivory Coast & Sassandra & near outlet & 4.9500 & -6.0504 & B & 79000 & 36.7 & N.A. & N.A. & GS & $\mathrm{U}$ & $\begin{array}{l}\text { Milliman and Fansworth, } \\
2011\end{array}$ & 1 \\
\hline
\end{tabular}




\begin{tabular}{|c|c|c|c|c|c|c|c|c|c|c|c|c|c|c|}
\hline ID & Country & $\begin{array}{c}\text { River/Catchment } \\
\text { Name }\end{array}$ & $\begin{array}{l}\text { Measuring } \\
\text { location }\end{array}$ & Lat $\left({ }^{\circ}\right)$ & $\operatorname{Lon}\left({ }^{\circ}\right)$ & $\begin{array}{l}\text { Coord. } \\
\text { Quality }\end{array}$ & $\mathbf{A}\left(\mathbf{k m}^{2}\right)$ & $\underset{\left(\mathbf{t} / \mathbf{k m}^{2} / \mathbf{y}\right)}{\mathbf{S Y}}$ & MP & $\begin{array}{c}\text { MP } \\
\text { length } \\
(\mathbf{y})\end{array}$ & Type & $\begin{array}{l}\text { Data } \\
\text { Quality }\end{array}$ & Reference & GIS \\
\hline & & & & & & & & & & & & & & \\
\hline 254 & Ivory Coast & Bandama & near outlet & 5.1512 & -4.9654 & B & 97000 & 74.2 & N.A. & N.A. & GS & $\mathrm{U}$ & $\begin{array}{l}\text { Milliman and Fansworth, } \\
2011\end{array}$ & 1 \\
\hline 255 & Kenya & Kaihungu & near Gatheru & -0.7438 & 37.0978 & A & 24 & 156 & 1991 & 1 & GS & $\mathrm{C}$ & Brown et al., 1996 & 1 \\
\hline 256 & Kenya & Tana & Masinga & -0.9130 & 37.5149 & A & 7335 & 6330 & $1981-1983$ & 3 & $\mathrm{R}$ & $\mathrm{U}$ & FAO, 2008 & 1 \\
\hline 257 & Kenya & Tana & Kamburu & -0.8309 & 37.6744 & A & 9520 & 410 & $1974-1981$ & 8 & $\mathrm{R}$ & $\mathrm{U}$ & FAO, 2008 & 1 \\
\hline 258 & Kenya & Tana & Kindaruma & -0.8134 & 37.8001 & A & 10000 & 238 & $1968-1981$ & 14 & $\mathrm{R}$ & $\mathrm{U}$ & FAO, 2008 & 1 \\
\hline 259 & Kenya & Tana & Grand Falls & -0.2692 & 37.9983 & $\mathrm{~B}$ & 17580 & 692 & $1948-1958$ & 11 & GS & $\mathrm{U}$ & FAO, 2008 & 1 \\
\hline 260 & Kenya & Mbagathi & Station: 3AA04 & -1.4087 & 36.8713 & $\mathrm{C}$ & 272 & 16.4 & N.A. & N.A. & GS & $\mathrm{C}$ & Kithiia, 1997 & 0 \\
\hline 261 & Kenya & Athi & Thwake & -1.7635 & 37.7158 & $\mathrm{C}$ & 5724 & 22.9 & N.A. & N.A. & GS & $\mathrm{C}$ & Kithiia, 1997 & 0 \\
\hline 262 & Kenya & Athi & Tsavo & -2.9759 & 38.5180 & $\mathrm{~B}$ & 10272 & 73.4 & N.A. & N.A. & GS & $\mathrm{C}$ & Kithiia, 1997 & 0 \\
\hline 263 & Kenya & Athi & L. Falls & -3.0383 & 38.6961 & $\mathrm{C}$ & 25203 & 81.6 & N.A. & N.A. & GS & $\mathrm{C}$ & Kithiia, 1997 & 0 \\
\hline 264 & Kenya & Nyando & $\begin{array}{l}\text { near outlet Lake } \\
\text { Victoria (?) }\end{array}$ & -0.2906 & 34.8743 & B & 3655 & 346 & $1950-2004$ & 54 & $\begin{array}{c}\text { GS } \\
\text { (TL) }\end{array}$ & $\mathrm{C}$ & Ma, 2006 & 1 \\
\hline 265 & Kenya & Nzoia & $\begin{array}{c}\text { near outlet Lake } \\
\text { Victoria }\end{array}$ & 0.0741 & 33.9809 & B & 13691 & 218 & $1950-2004$ & 54 & $\begin{array}{c}\text { GS } \\
\text { (TL) }\end{array}$ & $\mathrm{C}$ & Мa, 2006 & 1 \\
\hline 267 & Kenya & Thiba & Station: 4DA2 & -0.4139 & 37.3097 & $\mathrm{~B}$ & 32 & 20 & $1974-1977$ & 4 & GS & $\mathrm{C}$ & Ongweny, 1978 & 0 \\
\hline 268 & Kenya & Rupingazi & Station: 4DC3 & -0.5361 & 37.4375 & A & 197 & 37 & $1974-1977$ & 4 & GS & $\mathrm{C}$ & Ongweny, 1978 & 0 \\
\hline 269 & Kenya & Thiba & Station: 4DA10 & -0.6208 & 37.3167 & A & 353 & 74 & $1974-1977$ & 4 & GS & $\mathrm{C}$ & Ongweny, 1978 & 0 \\
\hline 270 & Kenya & Nyamindi & Station: 4DB4 & -0.6153 & 37.3694 & A & 375 & 12 & $1974-1977$ & 4 & GS & $\mathrm{C}$ & Ongweny, 1978 & 0 \\
\hline 271 & Kenya & $\begin{array}{l}\text { Nyamindi \& } \\
\text { Rupingazi }\end{array}$ & Station: 4DC2 & -0.7278 & 37.4889 & A & 740 & 67 & $1974-1977$ & 4 & GS & $\mathrm{C}$ & Ongweny, 1978 & 0 \\
\hline 272 & Kenya & Thiba & Station: 4DD2 & -0.7317 & 37.5061 & A & 1500 & 308 & $1974-1977$ & 4 & GS & $\mathrm{C}$ & Ongweny, 1978 & 1 \\
\hline 273 & Kenya & Tana & Station: 4DE2 & -0.8981 & 37.5028 & $\mathrm{~A}$ & 6681 & 1002.8 & $1974-1977$ & 4 & GS & $\mathrm{B}$ & Ongweny, 1978 & 1 \\
\hline 274 & Kenya & Sirimon & $\begin{array}{c}\text { Isiolo-Nanyuki } \\
\text { road }\end{array}$ & 0.0551 & 37.2071 & A & 62 & 8.6 & N.A. & N.A. & GS & $\mathrm{C}$ & Ongwenyi et al., 1993 & 1 \\
\hline 275 & Kenya & Sagana & Kiganio & -0.8859 & 36.8626 & $\mathrm{~B}$ & 501 & 8.2 & N.A. & N.A. & GS & $\mathrm{C}$ & Ongwenyi et al., 1993 & 1 \\
\hline 276 & Kenya & Thiba & Machanga & -0.7712 & 37.6388 & $\mathrm{~B}$ & 1970 & 160 & N.A. & 2 & GS & $\mathrm{C}$ & Ongwenyi et al., 1993 & 1 \\
\hline 277 & Kenya & Nzoia & Broderick Falls & 0.5833 & 34.8002 & $\mathrm{~B}$ & 8500 & 50 & N.A. & 4 & GS & $\mathrm{C}$ & Ongwenyi et al., 1993 & 1 \\
\hline 278 & Kenya & Ruiru river & Ruiru dam & -1.0468 & 36.7541 & B & 67 & 154 & N.A. & N.A. & $\mathrm{R}$ & $\mathrm{B}$ & UN-WATER, 2006 & 1 \\
\hline 279 & Lesotho & Hololo & Khukhune & -28.7170 & 28.4046 & $\mathrm{~B}$ & 212 & 80 & 1978 - 1982 & 5 & GS & $\mathrm{U}$ & FAO, 2008 & 1 \\
\hline 280 & Lesotho & Maphutseng & Maphutsaneng & -30.3047 & 27.4733 & B & 323 & 500 & $1978-1982$ & 5 & GS & $\mathrm{U}$ & FAO, 2008 & 1 \\
\hline 281 & Lesotho & N. Phuthiatsana & Mapoteng & -29.1248 & 27.9635 & B & 386 & 2050 & $1976-1982$ & 7 & GS & $\mathrm{U}$ & FAO, 2008 & 1 \\
\hline
\end{tabular}




\begin{tabular}{|c|c|c|c|c|c|c|c|c|c|c|c|c|c|c|}
\hline ID & Country & $\begin{array}{l}\text { River/Catchment } \\
\text { Name }\end{array}$ & $\begin{array}{l}\text { Measuring } \\
\text { location }\end{array}$ & Lat $\left({ }^{\circ}\right)$ & Lon $\left(^{\circ}\right)$ & $\begin{array}{l}\text { Coord. } \\
\text { Quality }\end{array}$ & $\mathbf{A}\left(\mathbf{k m}^{2}\right)$ & $\underset{\left(\mathbf{t} / \mathbf{k m}^{2} / \mathbf{y}\right)}{\mathbf{S Y}}$ & MP & $\begin{array}{c}\text { MP } \\
\text { length } \\
\text { (y) }\end{array}$ & Type & $\begin{array}{c}\text { Data } \\
\text { Quality }\end{array}$ & Reference & GIS \\
\hline 283 & Lesotho & Matsoku & Seshote & -29.2714 & 28.5567 & A & 662 & 7 & $1978-1982$ & 5 & GS & $\mathrm{U}$ & FAO, 2008 & 1 \\
\hline 284 & Lesotho & Hlotse & Ha Setene & -28.9137 & 28.1083 & B & 728 & 790 & $1978-1982$ & 5 & GS & $\mathrm{U}$ & FAO, 2008 & 1 \\
\hline 285 & Lesotho & Khobelu & Tlokoeng & -29.2328 & 28.8785 & A & 852 & 14 & $1978-1982$ & 5 & GS & $\mathrm{U}$ & FAO, 2008 & 1 \\
\hline 286 & Lesotho & N. Phuthiatsana & Kolonyama & -29.0833 & 27.7162 & A & 905 & 740 & $1978-1982$ & 5 & GS & $\mathrm{U}$ & FAO, 2008 & 1 \\
\hline 287 & Lesotho & S. Phuthiatsana & Masianokeng & -28.9104 & 28.1301 & A & 945 & 1382 & $1976-1982$ & 7 & GS & $\mathrm{U}$ & FAO, 2008 & 1 \\
\hline 289 & Lesotho & Caledon & Mashili & -28.9813 & 28.2344 & $\mathrm{C}$ & 1560 & 730 & $1976-1982$ & 7 & GS & $\mathrm{U}$ & FAO, 2008 & 0 \\
\hline 290 & Lesotho & Senqu & Mokhotlong & -29.2822 & 29.0580 & A & 1660 & 30 & $1976-1982$ & 7 & GS & $\mathrm{U}$ & FAO, 2008 & 1 \\
\hline 291 & Lesotho & Malibamatso & Paray & -29.4848 & 28.6010 & B & 3240 & 60 & $1976-1982$ & 7 & GS & $\mathrm{U}$ & FAO, 2008 & 1 \\
\hline 292 & Lesotho & Senqu & Koma - Koma & -29.1057 & 28.0093 & $\mathrm{C}$ & 7950 & 70 & $1976-1982$ & 7 & GS & $\mathrm{U}$ & FAO, 2008 & 0 \\
\hline 293 & Lesotho & Senqu & White Hill & -30.0588 & 28.4733 & B & 10900 & 140 & $1976-1982$ & 7 & GS & $\mathrm{U}$ & FAO, 2008 & 1 \\
\hline 294 & Lesotho & Senqu & Seaka & -30.3889 & 27.5720 & B & 19875 & 210 & $1976-1982$ & 7 & GS & $\mathrm{U}$ & FAO, 2008 & 1 \\
\hline 295 & Liberia & Cavally (Cavalla) & near outlet & 4.3500 & -7.5330 & B & 28000 & 189.3 & N.A. & N.A. & GS & $\mathrm{U}$ & $\begin{array}{l}\text { Milliman and Fansworth, } \\
2011\end{array}$ & 1 \\
\hline 297 & Madagascar & Sakamaly & Migodo & -20.4171 & 45.0025 & B & 799 & 2440 & $1970-1971$ & 2 & GS & $\mathrm{U}$ & FAO, 2008 & 1 \\
\hline 298 & Madagascar & Morondava & Tslandava & -20.4335 & 44.1261 & B & 4255 & 1586 & $1970-1971$ & 2 & GS & $\mathrm{U}$ & FAO, 2008 & 1 \\
\hline 299 & Madagascar & Ikopa (Betsiboka) & near outlet & -15.8830 & 46.3330 & B & 30000 & 500 & N.A. & N.A. & GS & $\mathrm{U}$ & $\begin{array}{l}\text { Milliman and Fansworth, } \\
2011\end{array}$ & 1 \\
\hline 300 & Madagascar & Tsiribihina & near outlet & -19.7324 & 44.3571 & B & 45000 & 266.7 & N.A. & N.A. & GS & $\mathrm{U}$ & $\begin{array}{l}\text { Milliman and Fansworth, } \\
2011\end{array}$ & 1 \\
\hline 301 & Madagascar & Mangoky & near outlet & -21.3380 & 43.5446 & B & 59000 & 169.5 & N.A. & N.A. & GS & U & $\begin{array}{c}\text { Milliman and Fansworth, } \\
2011\end{array}$ & 1 \\
\hline 302 & Malawi & Mindawo & $\begin{array}{l}\text { near Malmbala } \\
\text { School }\end{array}$ & -15.9425 & 35.0912 & A & 0.05 & 1605 & N.A. & 2 & GS & A & Amphlett, 1984 & 1 \\
\hline 303 & Malawi & Mindawo 2 & $\begin{array}{c}\text { near Malmbala } \\
\text { School }\end{array}$ & -15.9478 & 35.0923 & A & 0.07 & 250 & N.A. & 1 & GS & A & Amphlett, 1984 & 1 \\
\hline 304 & Malawi & Bvumbwe & near Chigumula & -15.9317 & 35.0564 & A & 0.08 & 17.5 & N.A. & 2 & GS & A & Amphlett, 1984 & 1 \\
\hline 305 & Malawi & Mphezo & $\begin{array}{l}\text { near Malmbala } \\
\text { School }\end{array}$ & -15.9742 & 35.0848 & A & 0.13 & 13 & N.A. & 1 & GS & A & Amphlett, 1984 & 1 \\
\hline 306 & Malawi & Mlowe & outlet & -12.0881 & 34.0421 & A & 113 & 22.9 & 1997 & 1 & GS & $\mathrm{C}$ & Hecky et al., 2003 & 1 \\
\hline 307 & Malawi & Namkokwe & near Outlet & -14.2228 & 34.6411 & $\mathrm{C}$ & 129 & 53.5 & 1997 & 1 & GS & $\mathrm{C}$ & Hecky et al., 2003 & 0 \\
\hline 308 & Malawi & Nadzipulu & near outlet & -14.1719 & 34.5784 & $\mathrm{~B}$ & 224 & 88.4 & 1997 & 1 & GS & $\mathrm{C}$ & Hecky et al., 2003 & 1 \\
\hline 309 & Malawi & N. Rumphi & outlet & -10.6947 & 34.1919 & A & 680 & 233.8 & 1997 & 1 & GS & $\mathrm{C}$ & Hecky et al., 2003 & 1 \\
\hline 310 & Malawi & Dwambadzi & near outlet & -12.4085 & 34.1066 & $\mathrm{C}$ & 778 & 7.2 & 1997 & 1 & GS & $\mathrm{C}$ & Hecky et al., 2003 & 0 \\
\hline
\end{tabular}




\begin{tabular}{|c|c|c|c|c|c|c|c|c|c|c|c|c|c|c|}
\hline ID & Country & $\begin{array}{c}\text { River/Catchment } \\
\text { Name }\end{array}$ & $\begin{array}{l}\text { Measuring } \\
\text { location }\end{array}$ & Lat $\left(^{\circ}\right)$ & Lon $\left(^{\circ}\right)$ & $\begin{array}{l}\text { Coord. } \\
\text { Quality }\end{array}$ & $\mathbf{A}\left(\mathbf{k m}^{2}\right)$ & $\underset{\left(\mathbf{t} / \mathbf{k m}^{2} / \mathbf{y}\right)}{\mathbf{S Y}}$ & MP & $\begin{array}{c}\text { MP } \\
\text { length } \\
(\mathbf{y})\end{array}$ & Type & $\begin{array}{l}\text { Data } \\
\text { Quality }\end{array}$ & Reference & GIS \\
\hline
\end{tabular}

\begin{tabular}{|c|c|c|c|c|c|c|c|c|c|c|c|c|c|c|}
\hline 312 & Malawi & N. Rukuru & outlet & -9.9105 & 33.9331 & A & 1970 & 145.2 & 1997 & 1 & GS & $\mathrm{C}$ & Hecky et al., 2003 & 1 \\
\hline 313 & Malawi & Luweya & outlet & -11.7903 & 34.2052 & A & 2420 & 59.2 & 1997 & 1 & GS & $\mathrm{C}$ & Hecky et al., 2003 & 1 \\
\hline 314 & Malawi & Songwe & near outlet & -9.6894 & 33.9387 & $\mathrm{C}$ & 4280 & 661.3 & 1997 & 1 & GS & $\mathrm{C}$ & Hecky et al., 2003 & 0 \\
\hline 315 & Malawi & Dwangwa & near outlet & -12.6112 & 34.1715 & $\mathrm{~B}$ & 7650 & 47.6 & 1997 & 1 & GS & $\mathrm{C}$ & Hecky et al., 2003 & 1 \\
\hline 316 & Malawi & Linthipe & outlet & -13.8522 & 34.5592 & A & 8560 & 498.5 & 1997 & 1 & GS & $\mathrm{C}$ & Hecky et al., 2003 & 1 \\
\hline 317 & Malawi & Bua & near outlet & -12.7915 & 34.2511 & $\mathrm{~B}$ & 10700 & 47.9 & 1997 & 1 & GS & $\mathrm{C}$ & Hecky et al., 2003 & 1 \\
\hline 318 & Malawi & S. Rukuru & near outlet & -10.7538 & 34.2084 & B & 12110 & 19.3 & 1997 & 1 & GS & $\mathrm{C}$ & Hecky et al., 2003 & 1 \\
\hline 319 & Mali & Dounfing & near Same & 12.6845 & -8.0463 & A & 18 & 20.5 & $\begin{array}{c}\text { May } 1994 \text { - Apr } \\
1996 \\
\end{array}$ & 2 & GS & B & Droux et al., 2003 & 1 \\
\hline 320 & Mali & Djitiko & near Ouronima & 12.0979 & -8.4208 & A & 103 & 14.1 & $\begin{array}{c}\text { May } 1994 \text { - Apr } \\
1996\end{array}$ & 2 & GS & B & Droux et al., 2003 & 1 \\
\hline 321 & Mali & Belekoni & near Bougouni & 11.3492 & -7.4855 & B & 120 & 30.9 & $\begin{array}{c}\text { May } 1994 \text { - Apr } \\
1996\end{array}$ & 2 & GS & B & Droux et al., 2003 & 0 \\
\hline 322 & Mali & Niger & Bamako & 12.6289 & -7.9939 & B & 117000 & 4.9 & $1990-1992$ & 3 & GS & $\mathrm{U}$ & Liénou et al., 2005 & 1 \\
\hline 323 & Mali & Niger & Banankoro & 11.6925 & -8.6609 & B & 71000 & 8.2 & \begin{tabular}{|c|} 
HY 1991/1992 - HY \\
$1997 / 1998$ \\
\end{tabular} & 7 & GS & B & $\begin{array}{l}\text { Picouet et al., 2001; } \\
\text { Picouet, } 1999\end{array}$ & 1 \\
\hline 324 & Mali & Bani & Douna & 13.2116 & -5.9034 & B & 102000 & 3.9 & \begin{tabular}{|c|} 
HY 1991/1992 - HY \\
$1997 / 1998$ \\
\end{tabular} & 7 & GS & B & $\begin{array}{c}\text { Picouet et al., 2001; } \\
\text { Picouet, } 1999 \\
\end{array}$ & 1 \\
\hline 325 & Mali & Niger & Koulikoro & 12.8721 & -7.5435 & B & 120000 & 7.3 & \begin{tabular}{|c|} 
HY 1991/1992 - HY \\
$1997 / 1998$ \\
\end{tabular} & 7 & GS & B & $\begin{array}{l}\text { Picouet et al., 2001; } \\
\text { Picouet, } 1999\end{array}$ & 1 \\
\hline 326 & Mali & Niger & Ké-Macina & 13.9572 & -5.3568 & B & 141000 & 10.2 & \begin{tabular}{|c|} 
HY 1991/1992 - HY \\
$1997 / 1998$ \\
\end{tabular} & 7 & GS & B & $\begin{array}{l}\text { Picouet et al., 2001; } \\
\text { Picouet, } 1999\end{array}$ & 0 \\
\hline 327 & Morocco & Oued Saboun & Barrage de Saboun & 35.6686 & -5.7968 & $\mathrm{~A}$ & 7.7 & 2937.5 & $1991-1999$ & 9 & $\mathrm{R}$ & $\mathrm{B}$ & Abdellaoui et al., 2002 & 1 \\
\hline 328 & Morocco & Nakhla & Nakhla & 35.4461 & -5.4019 & A & 107 & 1576 & $1961-1986$ & 26 & $\mathrm{R}$ & $\mathrm{U}$ & FAO, 2008 & 1 \\
\hline 329 & Morocco & Mharhar & Ibn Battouta & 35.5939 & -5.9882 & $\mathrm{~A}$ & 178 & 3650 & $1977-1986$ & 10 & $\mathrm{R}$ & $\mathrm{U}$ & FAO, 2008 & 1 \\
\hline 330 & Morocco & Nekor & M.B.E.A. Khattabi & 35.0891 & -3.8106 & A & 780 & 4620 & $1981-1986$ & 6 & $\mathrm{R}$ & $\mathrm{U}$ & FAO, 2008 & 1 \\
\hline 331 & Morocco & Aoudour & $\begin{array}{c}\text { near Douar } \\
\text { Tayenza }\end{array}$ & 34.8090 & -5.1655 & B & 1039 & 3850 & $1969-? ?$ & N.A. & GS & $\mathrm{U}$ & FAO, 2008 & 1 \\
\hline 332 & Morocco & Issen & Abdelmoumen & 30.6909 & -9.2068 & $\mathrm{~A}$ & 1300 & 200 & $1981-1986$ & 6 & $\mathrm{R}$ & $\mathrm{U}$ & FAO, 2008 & 1 \\
\hline 333 & Morocco & Tessaout & Moulay Youssef & 31.6333 & -7.2568 & $\mathrm{~A}$ & 1441 & 1291 & $1970-1986$ & 17 & $\mathrm{R}$ & $\mathrm{U}$ & FAO, 2008 & 1 \\
\hline 334 & Morocco & N. Fis & Lalla Takerkoust & 31.3359 & -8.1423 & $\mathrm{~A}$ & 1707 & 1100 & $1935-1986$ & 52 & $\mathrm{R}$ & $\mathrm{U}$ & FAO, 2008 & 1 \\
\hline 335 & Morocco & Querrha & B Ouender & 34.5225 & -4.5657 & A & 1756 & 3590 & $1969-? ?$ & N.A. & GS & $\mathrm{U}$ & FAO, 2008 & 1 \\
\hline 336 & Morocco & Mellah & Oued Mellah & 33.4954 & -7.3316 & A & 1800 & 127.7 & $1931-? ?$ & N.A. & $\mathrm{R}$ & $\mathrm{U}$ & FAO, 2008 & 1 \\
\hline 337 & Morocco & Loukos & El Makhazine & 34.9430 & -5.7066 & A & 1820 & 1299 & $1979-1986$ & 8 & $\mathrm{R}$ & $\mathrm{U}$ & FAO, 2008 & 1 \\
\hline 338 & Morocco & Bou Sellem & unknown & 34.3963 & -5.6852 & $\mathrm{C}$ & 2300 & 100 & N.A. & N.A. & GS & $\mathrm{U}$ & FAO, 2008 & 0 \\
\hline 339 & Morocco & Inaouene & Touaba & 34.1612 & -4.7491 & B & 3324 & 1110 & $1969-? ?$ & N.A. & GS & $\mathrm{U}$ & FAO, 2008 & 1 \\
\hline
\end{tabular}




\begin{tabular}{|c|c|c|c|c|c|c|c|c|c|c|c|c|c|c|}
\hline ID & Country & $\begin{array}{l}\text { River/Catchment } \\
\text { Name }\end{array}$ & $\begin{array}{l}\text { Measuring } \\
\text { location }\end{array}$ & Lat $\left(^{\circ}\right)$ & Lon $\left(^{\circ}\right)$ & $\begin{array}{l}\text { Coord. } \\
\text { Quality }\end{array}$ & $\mathbf{A}\left(\mathbf{k m}^{2}\right)$ & $\underset{\left(\mathbf{t} / \mathbf{k m}^{2} / \mathbf{y}\right)}{\mathbf{S Y}}$ & MP & $\begin{array}{c}\text { MP } \\
\text { length } \\
\text { (y) }\end{array}$ & Type & $\begin{array}{c}\text { Data } \\
\text { Quality }\end{array}$ & Reference & GIS \\
\hline 340 & Morocco & Inaouene & Idris I & 34.1262 & \begin{tabular}{|l|}
-4.6644 \\
\end{tabular} & A & 3680 & 707 & $1972-1986$ & 15 & $\mathrm{R}$ & $\mathrm{U}$ & FAO, 2008 & 1 \\
\hline 341 & Morocco & Massa & $\begin{array}{l}\text { Youssef b } \\
\text { Tachfine }\end{array}$ & 29.8028 & -9.4664 & A & 3784 & 378 & $1973-1986$ & 14 & $\mathrm{R}$ & $\mathrm{U}$ & FAO, 2008 & 1 \\
\hline 342 & Morocco & Querrha & Ourtzarh & 34.5351 & -4.9556 & A & 4398 & 3340 & $1969-? ?$ & N.A. & GS & $\mathrm{U}$ & FAO, 2008 & 1 \\
\hline 343 & Morocco & Ziz & Hassan Eddakhil & 32.0041 & -4.4599 & A & 4400 & 511 & $1971-1986$ & 16 & $\mathrm{R}$ & $\mathrm{U}$ & FAO, 2008 & 1 \\
\hline 344 & Morocco & Sebou & A Timedrine & 33.8161 & -4.6398 & $\mathrm{~A}$ & 4429 & 590 & $1969-? ?$ & N.A. & GS & $\mathrm{U}$ & FAO, 2008 & 1 \\
\hline 346 & Morocco & Querrha & M'Jara & 34.5938 & \begin{tabular}{|l|l|}
-5.1978 \\
\end{tabular} & $\mathrm{~A}$ & 6183 & 3500 & $1969-? ?$ & N.A. & GS & $\mathrm{U}$ & FAO, 2008 & 1 \\
\hline 347 & Morocco & El Abid & Bin El Quidane & 32.0970 & \begin{tabular}{|l|l|}
-6.4028 \\
\end{tabular} & $\mathrm{~A}$ & 6400 & 675 & $1953-1986$ & 34 & $\mathrm{R}$ & $\mathrm{U}$ & FAO, 2008 & 1 \\
\hline 348 & Morocco & Bou Regreg & $\begin{array}{l}\text { S. Mohamed b } \\
\text { Abdellah }\end{array}$ & 33.9391 & -6.7267 & A & 9800 & 338 & 1974 - 1986 & 13 & $\mathrm{R}$ & $\mathrm{U}$ & FAO, 2008 & 1 \\
\hline 349 & Morocco & Sebou & Pont Sebou & 34.2991 & \begin{tabular}{|l|l|}
-5.1348 \\
\end{tabular} & $\mathrm{~B}$ & 12985 & 750 & $1969-? ?$ & N.A. & GS & $\mathrm{U}$ & FAO, 2008 & 1 \\
\hline 350 & Morocco & Draa & Mansour Eddahbi & 30.9231 & \begin{tabular}{|l|l}
-6.7895 \\
\end{tabular} & $\mathrm{~B}$ & 15000 & 410 & $1972-1986$ & 15 & $\mathrm{R}$ & $\mathrm{U}$ & FAO, 2008 & 0 \\
\hline 351 & Morocco & Sebou & Azib Soltane & 34.2803 & -5.4384 & B & 16276 & 650 & 1969 - ?? & N.A. & GS & $\mathrm{U}$ & FAO, 2008 & 1 \\
\hline 352 & Morocco & Er Rbia & Al Massira & 32.4559 & \begin{tabular}{|l|}
-7.5641 \\
\end{tabular} & $\mathrm{~B}$ & 28500 & 415 & $1979-1986$ & 8 & $\mathrm{R}$ & $\mathrm{U}$ & FAO, 2008 & 1 \\
\hline 354 & Morocco & Moulouya & Mohammed V & 34.6459 & -2.9614 & $\mathrm{~B}$ & 49920 & 383 & $1976-1986$ & 11 & $\mathrm{R}$ & $\mathrm{U}$ & FAO, 2008 & 1 \\
\hline 355 & Morocco & Sra & near Bouhouda & 34.6804 & -4.5746 & B & 493 & 3500 & N.A. & N.A. & GS & $\mathrm{U}$ & Hooke, 2006 & 1 \\
\hline 356 & Morocco & Lakhdar & Sidi Driss & 31.8432 & -7.0747 & A & 2850 & 370 & N.A. & N.A. & GS & $\mathrm{U}$ & Jansson, 1982 & 1 \\
\hline 357 & Morocco & Sebou & Pont du Mdez & 33.7049 & -4.5151 & A & 3474 & 320 & N.A. & N.A. & GS & $\mathrm{U}$ & Jansson, 1982 & 1 \\
\hline 358 & Morocco & Sebou & Azzaba & 33.8238 & -4.6945 & $\mathrm{~B}$ & 4736 & 530 & N.A. & N.A. & GS & $\mathrm{U}$ & Jansson, 1982 & 0 \\
\hline 359 & Morocco & Grou & unknown & 33.9379 & -6.7503 & $\mathrm{C}$ & 5540 & 300 & N.A. & N.A. & $\mathrm{R}$ & $\mathrm{U}$ & Jansson, 1982 & 0 \\
\hline 360 & Morocco & Souss & near outlet & 30.3488 & -9.6160 & B & 16000 & 262.5 & N.A. & N.A. & GS & $\mathrm{U}$ & $\begin{array}{l}\text { Milliman and Fansworth, } \\
2011 \\
\end{array}$ & 1 \\
\hline 361 & Morocco & Sebou & near outlet & 34.2586 & -6.6722 & B & 37000 & 1000 & N.A. & N.A. & GS & $\mathrm{U}$ & $\begin{array}{l}\text { Milliman and Fansworth, } \\
2011 \\
\end{array}$ & 1 \\
\hline 362 & Morocco & Moulouya & near outlet & 35.1162 & -2.3492 & B & 51000 & 235.3 & N.A. & N.A. & GS & $\mathrm{U}$ & $\begin{array}{l}\text { Milliman and Fansworth, } \\
2011\end{array}$ & 1 \\
\hline 363 & Morocco & Draa & near outlet & 28.6989 & -11.1647 & B & 114000 & 122.8 & N.A. & N.A. & GS & U & $\begin{array}{l}\text { Milliman and Fansworth, } \\
2011\end{array}$ & 0 \\
\hline 364 & Morocco & Oued MJara & Barrage El Wahda & 34.5966 & -5.1985 & $\mathrm{~B}$ & 5190 & 2910 & N.A. & N.A. & GS & $\mathrm{U}$ & Walling, 1984 & 1 \\
\hline 365 & Mozambique & & Kabora Bassa & -15.6707 & 31.8361 & $\mathrm{~B}$ & 1000000 & 134.5 & N.A. & N.A. & $\mathrm{R}$ & $\mathrm{C}$ & Bolton, 1984 & 0 \\
\hline 366 & Mozambique & Limpopo & near outlet & -25.0771 & 33.5812 & B & 410000 & 80.5 & N.A. & N.A. & GS & $\mathrm{U}$ & $\begin{array}{l}\text { Milliman and Fansworth, } \\
2011 \\
\end{array}$ & 1 \\
\hline
\end{tabular}




\begin{tabular}{|c|c|c|c|c|c|c|c|c|c|c|c|c|c|c|}
\hline ID & Country & $\begin{array}{c}\text { River/Catchment } \\
\text { Name }\end{array}$ & $\begin{array}{l}\text { Measuring } \\
\text { location }\end{array}$ & Lat $\left(^{\circ}\right)$ & Lon $\left(^{\circ}\right)$ & $\begin{array}{l}\text { Coord. } \\
\text { Quality }\end{array}$ & $\mathbf{A}\left(\mathbf{k m}^{2}\right)$ & $\underset{\left(\mathbf{t} / \mathbf{k m}^{2} / \mathbf{y}\right)}{\mathbf{S Y}}$ & MP & $\begin{array}{l}\text { MP } \\
\text { length } \\
\text { (y) }\end{array}$ & Type & $\begin{array}{l}\text { Data } \\
\text { Quality }\end{array}$ & Reference & GIS \\
\hline & & & & & & & & & & & & & & \\
\hline 368 & Niger & Sirba & Tiambi & 13.5289 & 1.3836 & B & 37370 & 18.1 & \begin{tabular}{|c|} 
HY 2006/2007 - HY \\
$2007 / 2008$
\end{tabular} & 2 & GS & A & Amogu, 2009 & 1 \\
\hline 369 & Niger & Sirba & Garbe Kourou & 13.7316 & 1.6049 & B & 38704 & 24.8 & $\begin{array}{c}\text { HY 2006/2007 - HY } \\
2007 / 2008 \\
\end{array}$ & 2 & GS & A & Amogu, 2009 & 1 \\
\hline 370 & Niger & Gorouol & Alcongui & 14.7486 & 0.5977 & B & 44540 & 17.7 & $\begin{array}{c}\text { HY 2006/2007 - HY } \\
2007 / 2008 \\
\end{array}$ & 2 & GS & A & Amogu, 2009 & 1 \\
\hline 371 & Niger & Niger & Farié-Haossa & 13.7836 & 1.6495 & $\mathrm{~B}$ & 650380 & 19.6 & HY 2007/2008 & 1 & GS & A & Amogu, 2009 & 1 \\
\hline 372 & Niger & Niger & Latakabiey & 13.7583 & 1.6793 & $\mathrm{~B}$ & 689130 & 19.6 & HY 2007/2008 & 1 & GS & A & Amogu, 2009 & 1 \\
\hline 373 & Niger & Niger & Brigambou & 12.4672 & 2.7396 & $\mathrm{~B}$ & 736250 & 15.2 & HY 2007/2008 & 1 & GS & A & Amogu, 2009 & 0 \\
\hline 374 & Niger & Niger & Diabou-Kiria & 12.2740 & 2.9870 & $\mathrm{~B}$ & 757640 & 15.1 & HY 2007/2008 & 1 & GS & A & Amogu, 2009 & 0 \\
\hline 375 & Niger & Gorouol & Dolbel & 14.6167 & 0.2833 & B & 7500 & 22.1 & \begin{tabular}{|c|} 
HY 1976/1977 - HY \\
$1982-1983$ \\
\end{tabular} & 7 & GS & B & $\begin{array}{c}\text { Amogu, 2009; Gallaire, } \\
1986 \\
\end{array}$ & 1 \\
\hline 376 & Niger & Niger & Niamey & 13.5030 & 2.1070 & B & 700000 & 12.6 & \begin{tabular}{|c|} 
HY 1984/1985 - HY \\
1985/1986; HY \\
2006/2007 - HY \\
2007/2008 \\
\end{tabular} & 4 & GS & B & $\begin{array}{l}\text { Gallaire, 1986; Amogu, } \\
2009\end{array}$ & 1 \\
\hline 377 & Niger & Niger & Kandadji & 14.6146 & 0.9659 & B & 628830 & 4.8 & $\begin{array}{c}\text { HY 1976/1977 - HY } \\
\text { 1982/1983; HY } \\
\text { 2007/2008 } \\
\end{array}$ & 8 & GS & B & $\begin{array}{l}\text { Gallaire, 1986; Amogu, } \\
2009\end{array}$ & 1 \\
\hline 378 & Nigeria & Niger & $\begin{array}{l}\text { near confluence } \\
\text { with Benue }\end{array}$ & 7.7603 & 6.7603 & B & 133000 & 68 & N.A. & N.A. & GS & $\mathrm{U}$ & $\begin{array}{c}\text { Dedkov and Mozzherin, } \\
1984 \\
\end{array}$ & 0 \\
\hline 379 & Nigeria & Benue & near Lokoja & 7.9045 & 6.9663 & B & 300000 & 73 & N.A. & N.A. & GS & U & $\begin{array}{c}\text { Dedkov and Mozzherin, } \\
1984 \\
\end{array}$ & 1 \\
\hline 380 & Nigeria & Sokoto & Gusau & 12.1443 & 6.6678 & $\mathrm{~A}$ & 2653 & 257 & $1962-1965$ & 4 & GS & $\mathrm{U}$ & FAO, 2008 & 1 \\
\hline 381 & Nigeria & Zamfara & Anka & 12.1213 & 5.9213 & $\mathrm{~A}$ & 4126 & 344 & $1962-1965$ & 4 & GS & $\mathrm{U}$ & FAO, 2008 & 1 \\
\hline 382 & Nigeria & Gagare & Kaura Namoda & 12.6016 & 6.5874 & $\mathrm{~A}$ & 6172 & 225 & $1962-1965$ & 4 & GS & $\mathrm{U}$ & FAO, 2008 & 1 \\
\hline 383 & Nigeria & Bunsuru & Zurmi & 12.7723 & 6.7873 & A & 6826 & 161 & $1962-1965$ & 4 & GS & $\mathrm{U}$ & FAO, 2008 & 0 \\
\hline 384 & Nigeria & Sokoto & Sokoto & 13.0784 & 5.2629 & B & 12851 & 212 & $1962-1965$ & 4 & GS & $\mathrm{U}$ & FAO, 2008 & 1 \\
\hline 385 & Nigeria & Zamfara & Kalgo & 12.3213 & 4.1999 & B & 16678 & 38 & $1962-1965$ & 4 & GS & $\mathrm{U}$ & FAO, 2008 & 1 \\
\hline 386 & Nigeria & Rima & Sabon Birni & 12.5804 & 6.8813 & $\mathrm{C}$ & 19832 & 100 & $1962-1965$ & 4 & GS & $\mathrm{U}$ & FAO, 2008 & 0 \\
\hline 387 & Nigeria & Rima & Argungu & 12.7572 & 4.5290 & $\mathrm{C}$ & 43490 & 7 & $1964-1965$ & 2 & GS & $\mathrm{U}$ & FAO, 2008 & 1 \\
\hline 388 & Nigeria & Ogun & near outlet & 6.5755 & 3.4388 & B & 47000 & 23.4 & N.A. & N.A. & GS & $\mathrm{U}$ & $\begin{array}{l}\text { Milliman and Fansworth, } \\
2011\end{array}$ & 0 \\
\hline 389 & Nigeria & Cross & near outlet & 4.6403 & 8.4293 & B & 60000 & 125 & N.A. & N.A. & GS & $\mathrm{U}$ & $\begin{array}{l}\text { Milliman and Fansworth, } \\
2011 \\
\end{array}$ & 1 \\
\hline 390 & Nigeria & Niger & near outlet & 4.7212 & 6.7858 & B & 2200000 & 18.2 & N.A. & N.A. & GS & $\mathrm{U}$ & $\begin{array}{l}\text { Milliman and Fansworth, } \\
2011 \\
\end{array}$ & 1 \\
\hline
\end{tabular}




\begin{tabular}{|c|c|c|c|c|c|c|c|c|c|c|c|c|c|c|}
\hline ID & Country & $\begin{array}{c}\text { River/Catchment } \\
\text { Name }\end{array}$ & $\begin{array}{l}\text { Measuring } \\
\text { location }\end{array}$ & Lat $\left({ }^{\circ}\right)$ & $\operatorname{Lon}\left({ }^{\circ}\right)$ & $\begin{array}{l}\text { Coord. } \\
\text { Quality }\end{array}$ & $\mathbf{A}\left(\mathbf{k m}^{2}\right)$ & $\begin{array}{c}\mathrm{SY} \\
\left(\mathbf{t} / \mathbf{k m}^{2} / \mathbf{y}\right)\end{array}$ & MP & $\begin{array}{c}\text { MP } \\
\text { length } \\
(\mathbf{y})\end{array}$ & Type & $\begin{array}{l}\text { Data } \\
\text { Quality }\end{array}$ & Reference & GIS \\
\hline & & & & & & & & & & & & & & \\
\hline 391 & Senegal & Gambie & Kedougou & 12.5511 & -12.1669 & A & 7500 & 7.9 & $1987-1987$ & 1 & GS & $\mathrm{U}$ & Liénou et al., 2005 & 1 \\
\hline 392 & Senegal & Gambie & Gouloumbou & 13.4809 & -13.7458 & $\mathrm{~B}$ & 42000 & 2.1 & $1983-1984$ & 2 & GS & $\mathrm{U}$ & Liénou et al., 2005 & 1 \\
\hline 393 & Senegal & Sénégal & Bakel & 14.9047 & -12.4522 & $\mathrm{~B}$ & 218000 & 10.3 & $1979-1987$ & 9 & GS & $\mathrm{U}$ & Liénou et al., 2005 & 0 \\
\hline 394 & Senegal & Sénégal & Dagana & 16.5220 & -15.5129 & $\mathrm{~B}$ & 270000 & 10.6 & $1981-1983$ & 3 & GS & $\mathrm{U}$ & Liénou et al., 2005 & 0 \\
\hline 395 & Senegal & Sénégal & near outlet & 16.1262 & -16.4864 & B & 270000 & 11.1 & N.A. & N.A. & GS & $\mathrm{U}$ & $\begin{array}{l}\text { Milliman and Fansworth, } \\
2011\end{array}$ & 1 \\
\hline 396 & South Africa & & Mpanamana & -25.3083 & 31.9735 & $\mathrm{~A}$ & 8.1 & 50 & $1957-2008$ & 52 & $\mathrm{R}$ & $\mathrm{A}$ & Baade et al., 2012 & 1 \\
\hline 397 & South Africa & & Makhohlola & -25.2557 & 31.8598 & $\mathrm{~A}$ & 13 & 10 & $1963-2008$ & 46 & $\mathrm{R}$ & $\mathrm{A}$ & Baade et al., 2012 & 1 \\
\hline 398 & South Africa & & Silolweni & -24.8226 & 31.8365 & $\mathrm{~A}$ & 14 & 50 & $1969-2008$ & 40 & $\mathrm{R}$ & $\mathrm{A}$ & Baade et al., 2012 & 1 \\
\hline 399 & South Africa & & Nhlanganzwane & -25.2325 & 31.9752 & $\mathrm{~A}$ & 14 & 60 & $1956-2008$ & 53 & $\mathrm{R}$ & $\mathrm{A}$ & Baade et al., 2012 & 1 \\
\hline 400 & South Africa & & Mlondozi & -25.0350 & 31.9339 & $\mathrm{~A}$ & 101 & 11 & $1951-2008$ & 58 & $\mathrm{R}$ & $\mathrm{A}$ & Baade et al., 2012 & 1 \\
\hline 401 & South Africa & Oranje & Aliwal North & -30.6818 & 26.7117 & $\mathrm{~B}$ & 37000 & 480 & N.A. & 13 & GS & $\mathrm{U}$ & $\begin{array}{l}\text { Dedkov and Mozzherin, } \\
1984\end{array}$ & 1 \\
\hline 402 & South Africa & Oranje & Prieska & -29.6608 & 22.7566 & $\mathrm{~B}$ & 820000 & 85 & N.A. & 18 & GS & $\mathrm{U}$ & $\begin{array}{c}\text { Dedkov and Mozzherin, } \\
1984\end{array}$ & 0 \\
\hline 403 & South Africa & Oranje & Bethulie & -30.5362 & 25.9704 & $\mathrm{C}$ & 6362 & 890 & $1929-1969$ & 41 & GS & $\mathrm{U}$ & FAO, 2008 & 0 \\
\hline 404 & South Africa & & $\begin{array}{c}\text { Compassberg Dam } \\
10\end{array}$ & -31.7200 & 24.5683 & A & 1.5 & 445 & $1970-2003$ & 34 & $\mathrm{R}$ & B & Foster et al., 2012 & 1 \\
\hline 405 & South Africa & & $\begin{array}{c}\text { Compassberg Dam } \\
7 \\
\end{array}$ & -31.7206 & 24.5675 & A & 6.3 & 153 & $1970-2007$ & 38 & $\mathrm{R}$ & B & Foster et al., 2012 & 1 \\
\hline 406 & South Africa & & Cranemere & -32.5305 & 24.9872 & $\mathrm{~A}$ & 58 & 175 & $1970-2007$ & 38 & $\mathrm{R}$ & B & Foster et al., 2012 & 0 \\
\hline 407 & South Africa & Kromme & near outlet & -34.1367 & 24.8439 & $\mathrm{~B}$ & 900 & 200 & N.A. & N.A. & GS & $\mathrm{U}$ & $\begin{array}{l}\text { Milliman and Fansworth, } \\
2011\end{array}$ & 1 \\
\hline 408 & South Africa & Matigulu & near outlet & -29.1143 & 31.6170 & B & 1000 & 220 & N.A. & N.A. & GS & $\mathrm{U}$ & $\begin{array}{l}\text { Milliman and Fansworth, } \\
2011\end{array}$ & 1 \\
\hline 409 & South Africa & Keurbooms & near outlet & -34.0295 & 23.3987 & $\mathrm{~B}$ & 1100 & 181.8 & N.A. & N.A. & GS & $\mathrm{U}$ & $\begin{array}{l}\text { Milliman and Fansworth, } \\
2011\end{array}$ & 1 \\
\hline 410 & South Africa & $\begin{array}{l}\text { Umtamvuna } \\
\text { (Mtamvuna) }\end{array}$ & near outlet & -31.1006 & 30.2266 & $\mathrm{~B}$ & 1500 & 286.7 & N.A. & N.A. & GS & $\mathrm{U}$ & $\begin{array}{l}\text { Milliman and Fansworth, } \\
2011\end{array}$ & 0 \\
\hline 411 & South Africa & Umvoti (Mvoti) & near outlet & -29.3807 & 31.3367 & B & 2800 & 289.3 & N.A. & N.A. & GS & $\mathrm{U}$ & $\begin{array}{l}\text { Milliman and Fansworth, } \\
2011\end{array}$ & 1 \\
\hline 412 & South Africa & $\begin{array}{l}\text { Umhlantuzi } \\
\text { (Mhlantuzi) }\end{array}$ & near outlet & -28.8170 & 32.0830 & $\mathrm{~B}$ & 3700 & 297.3 & N.A. & N.A. & GS & $\mathrm{U}$ & $\begin{array}{l}\text { Milliman and Fansworth, } \\
2011\end{array}$ & 1 \\
\hline 413 & South Africa & $\begin{array}{l}\text { Umkomazi } \\
\text { (Mkomaas) }\end{array}$ & near outlet & -30.1856 & 30.8185 & B & 4300 & 372.1 & N.A. & N.A. & GS & $\mathrm{U}$ & $\begin{array}{l}\text { Milliman and Fansworth, } \\
2011\end{array}$ & 1 \\
\hline 414 & South Africa & Umgeni (Mgeni) & near outlet & -29.8765 & 31.0619 & $\mathrm{~B}$ & 4400 & 386.4 & N.A. & N.A. & GS & $\mathrm{U}$ & $\begin{array}{l}\text { Milliman and Fansworth, } \\
2011\end{array}$ & 0 \\
\hline
\end{tabular}




\begin{tabular}{|c|c|c|c|c|c|c|c|c|c|c|c|c|c|c|}
\hline ID & Country & $\begin{array}{c}\text { River/Catchment } \\
\text { Name }\end{array}$ & $\begin{array}{l}\text { Measuring } \\
\text { location }\end{array}$ & Lat $\left(^{\circ}\right)$ & Lon $\left(^{\circ}\right)$ & $\begin{array}{l}\text { Coord. } \\
\text { Quality }\end{array}$ & $\mathbf{A}\left(\mathbf{k m}^{2}\right)$ & $\underset{\left(\mathbf{t} / \mathbf{k m}^{2} / \mathbf{y}\right)}{\mathbf{S Y}}$ & MP & $\begin{array}{c}\text { MP } \\
\text { length } \\
(\mathbf{y})\end{array}$ & Type & $\begin{array}{l}\text { Data } \\
\text { Quality }\end{array}$ & Reference & GIS \\
\hline & & & & & & & & & & & & & & \\
\hline 415 & South Africa & Umfolozi (Mfolozi) & near outlet & -28.4541 & 32.4253 & B & 10000 & 240 & N.A. & N.A. & GS & $\mathrm{U}$ & $\begin{array}{l}\text { Milliman and Fansworth, } \\
2011\end{array}$ & 1 \\
\hline 416 & South Africa & $\begin{array}{l}\text { Umzimvubu } \\
\text { (Mzimvubu) }\end{array}$ & near outlet & -31.6262 & 29.5536 & B & 16000 & 137.5 & N.A. & N.A. & GS & $\mathrm{U}$ & $\begin{array}{l}\text { Milliman and Fansworth, } \\
2011\end{array}$ & 1 \\
\hline 417 & South Africa & Tugela (Thukela) & near outlet & -29.2172 & 31.4892 & B & 29000 & 303.4 & N.A. & N.A. & GS & $\mathrm{U}$ & $\begin{array}{l}\text { Milliman and Fansworth, } \\
2011\end{array}$ & 1 \\
\hline 418 & South Africa & Oranje & near outlet & -28.6192 & 16.4507 & B & 1000000 & 89 & N.A. & N.A. & GS & $\mathrm{U}$ & $\begin{array}{l}\text { Milliman and Fansworth, } \\
2011\end{array}$ & 1 \\
\hline 419 & South Africa & Brak & Ernest Robinson & -33.9022 & 22.1743 & A & 10 & 12 & $1955-1985$ & 30 & $\mathrm{R}$ & $\mathrm{B}$ & Rooseboom et al., 1992 & 1 \\
\hline 420 & South Africa & Broederstroom & Dap Naude & -23.8145 & 29.9663 & A & 14 & 357 & $1961-1987$ & 26 & $\mathrm{R}$ & B & Rooseboom et al., 1992 & 1 \\
\hline 421 & South Africa & Le Roux & Melville & -33.3965 & 22.3142 & $\mathrm{C}$ & 18 & 1 & $1945-1984$ & 39 & $\mathrm{R}$ & B & Rooseboom et al., 1992 & 0 \\
\hline 422 & South Africa & Gubu & Gubu & -32.6040 & 27.2738 & A & 23 & 161 & $1970-1981$ & 11 & $\mathrm{R}$ & B & Rooseboom et al., 1992 & 1 \\
\hline 423 & South Africa & Wit & Longmere & -25.2806 & 31.0009 & A & 27 & 250 & $1940-1979$ & 39 & $\mathrm{R}$ & B & Rooseboom et al., 1992 & 0 \\
\hline 424 & South Africa & Buffems & Maden & -32.7397 & 27.2994 & A & 30 & 42 & $1909-1981$ & 72 & $\mathrm{R}$ & B & Rooseboom et al., 1992 & 1 \\
\hline 425 & South Africa & Korinte & Korentepoort & -33.9986 & 21.1657 & A & 37 & 33 & $1965-1983$ & 18 & $\mathrm{R}$ & B & Rooseboom et al., 1992 & 1 \\
\hline 426 & South Africa & Le Roux & Raubenheimer & -33.4096 & 22.2815 & A & 43 & 7 & $1973-1984$ & 11 & $\mathrm{R}$ & B & Rooseboom et al., 1992 & 0 \\
\hline 428 & South Africa & Konings & Klipberg & -33.9422 & 19.7941 & A & 54 & 1 & $1964-1983$ & 19 & $\mathrm{R}$ & $\mathrm{B}$ & Rooseboom et al., 1992 & 1 \\
\hline 429 & South Africa & Stettynskloof & Stettynskloof & -33.8363 & 19.2524 & A & 55 & 54 & $1954-1984$ & 30 & $\mathrm{R}$ & B & Rooseboom et al., 1992 & 1 \\
\hline 430 & South Africa & Sanddrif & Roode Elsburg & -33.4364 & 19.5685 & $\mathrm{C}$ & 59 & 202 & $1968-1983$ & 15 & $\mathrm{R}$ & $\mathrm{B}$ & Rooseboom et al., 1992 & 0 \\
\hline 431 & South Africa & Witwaters & Da Gama & -25.1412 & 31.0209 & A & 62 & 566 & $1971-1979$ & 8 & $\mathrm{R}$ & B & Rooseboom et al., 1992 & 1 \\
\hline 432 & South Africa & Leeu & Weltevrede & -27.2231 & 27.5702 & A & 63 & 377 & $1907-1978$ & 71 & $\mathrm{R}$ & $\mathrm{B}$ & Rooseboom et al., 1992 & 1 \\
\hline 433 & South Africa & Politsi & Magoebaskloof & -23.8173 & 30.0555 & A & 64 & 76 & $1970-1986$ & 16 & $\mathrm{R}$ & B & Rooseboom et al., 1992 & 1 \\
\hline 434 & South Africa & Sand & Witteklip & -25.2377 & 30.8980 & A & 64 & 160 & $1969-1979$ & 10 & $\mathrm{R}$ & $\mathrm{B}$ & Rooseboom et al., 1992 & 1 \\
\hline 435 & South Africa & Wit & Klipkopjes & -25.2206 & 31.0080 & A & 78 & 234 & $1960-1979$ & 19 & $\mathrm{R}$ & B & Rooseboom et al., 1992 & 1 \\
\hline 436 & South Africa & Matjesvlei & Menin & -28.0850 & 28.2773 & A & 80 & 44 & $1922-1978$ & 56 & $\mathrm{R}$ & $\mathrm{B}$ & Rooseboom et al., 1992 & 1 \\
\hline 437 & South Africa & Leeu & Roodepoort & -25.3870 & 29.4966 & $\mathrm{C}$ & 80 & 271 & $1896-1978$ & 82 & $\mathrm{R}$ & B & Rooseboom et al., 1992 & 0 \\
\hline 438 & South Africa & Ramadiepa & Hans Merensky & -23.7504 & 30.1077 & A & 88 & 25 & $1935-1987$ & 52 & $\mathrm{R}$ & $\mathrm{B}$ & Rooseboom et al., 1992 & 1 \\
\hline 439 & South Africa & Groot & Poortjieskloof & -33.8582 & 20.3714 & A & 94 & 103 & $1957-1979$ & 22 & $\mathrm{R}$ & B & Rooseboom et al., 1992 & 1 \\
\hline 440 & South Africa & Gamka & Gamka & -32.2387 & 22.5865 & A & 98 & 70 & $1955-1980$ & 25 & $\mathrm{R}$ & $\mathrm{B}$ & Rooseboom et al., 1992 & 1 \\
\hline 441 & South Africa & Hartenbos & Hartebeeskuil & -34.0965 & 22.0076 & A & 100 & 7 & $1969-1981$ & 12 & $\mathrm{R}$ & B & Rooseboom et al., 1992 & 1 \\
\hline 442 & South Africa & Nwandezi & Nwanedzi & -22.6349 & 30.3988 & A & 109 & 14 & $1963-1979$ & 16 & $\mathrm{R}$ & $\mathrm{B}$ & Rooseboom et al., 1992 & 1 \\
\hline 443 & South Africa & Keisies & Pietersfontein & -33.6676 & 20.0117 & A & 116 & 269 & $1968-1981$ & 13 & $\mathrm{R}$ & B & Rooseboom et al., 1992 & 1 \\
\hline
\end{tabular}




\begin{tabular}{|c|c|c|c|c|c|c|c|c|c|c|c|c|c|c|}
\hline ID & Country & $\begin{array}{c}\text { River/Catchment } \\
\text { Name }\end{array}$ & $\begin{array}{l}\text { Measuring } \\
\text { location }\end{array}$ & Lat $\left(^{\circ}\right)$ & Lon $\left(^{\circ}\right)$ & $\begin{array}{l}\text { Coord. } \\
\text { Quality }\end{array}$ & $\mathbf{A}\left(\mathbf{k m}^{2}\right)$ & $\underset{\left(\mathbf{t} / \mathbf{k m}^{2} / \mathbf{y}\right)}{\mathbf{S Y}}$ & MP & $\begin{array}{c}\text { MP } \\
\text { length } \\
(\mathbf{y})\end{array}$ & Type & $\begin{array}{c}\text { Data } \\
\text { Quality }\end{array}$ & Reference & GIS \\
\hline
\end{tabular}

\begin{tabular}{|c|c|c|c|c|c|c|c|c|c|c|c|c|c|c|}
\hline 445 & South Africa & Wemmershoek & Wemmershoek & -33.8332 & 19.0820 & $\mathrm{~B}$ & 125 & 310 & $1957-1984$ & 27 & $\mathrm{R}$ & B & Rooseboom et al., 1992 & 1 \\
\hline 446 & South Africa & Cordiers & Oukloof & -33.2478 & 22.0992 & A & 141 & 54 & $1929-1984$ & 55 & $\mathrm{R}$ & B & Rooseboom et al., 1992 & 1 \\
\hline 447 & South Africa & Loerie & Loerie & -33.8653 & 25.0392 & $\mathrm{~A}$ & 147 & 280 & $1971-1984$ & 13 & $\mathrm{R}$ & B & Rooseboom et al., 1992 & 1 \\
\hline 448 & South Africa & Duiwenhoks & Duiwenhoks & -33.9970 & 20.9489 & A & 148 & 20 & $1965-1979$ & 14 & $\mathrm{R}$ & B & Rooseboom et al., 1992 & 1 \\
\hline 450 & South Africa & Klip & Windsor & -28.4956 & 29.7405 & $\mathrm{C}$ & 150 & 315 & $1957-1990$ & 33 & $\mathrm{R}$ & B & Rooseboom et al., 1992 & 0 \\
\hline 451 & South Africa & Mnyamvubu & Craigie Burn & -29.1625 & 30.2874 & $\mathrm{~A}$ & 152 & 29 & $1963-1983$ & 20 & $\mathrm{R}$ & B & Rooseboom et al., 1992 & 1 \\
\hline 452 & South Africa & Letaba & Ebenezer & -23.9411 & 29.9790 & A & 156 & 155 & $1959-1986$ & 27 & $\mathrm{R}$ & B & Rooseboom et al., 1992 & 1 \\
\hline 453 & South Africa & Wit & Primkop & -25.3835 & 31.0710 & $\mathrm{~A}$ & 158 & 55 & $1970-1987$ & 17 & $\mathrm{R}$ & B & Rooseboom et al., 1992 & 0 \\
\hline 454 & South Africa & Klaserie & Jan Wassenaar & -24.5238 & 31.0700 & A & 165 & 121 & $1960-1979$ & 19 & $\mathrm{R}$ & B & Rooseboom et al., 1992 & 1 \\
\hline 455 & South Africa & Sterk & Welgevonden & -33.9015 & 18.8576 & $\mathrm{C}$ & 166 & 6 & $1954-1977$ & 23 & $\mathrm{R}$ & B & Rooseboom et al., 1992 & 0 \\
\hline 456 & South Africa & Nels & Calitzdorp & -33.4872 & 21.7055 & A & 170 & 135 & $1917-1981$ & 64 & $\mathrm{R}$ & B & Rooseboom et al., 1992 & 1 \\
\hline 457 & South Africa & Dorps & Combrink & -24.1633 & 29.0317 & A & 174 & 15 & $1964-1978$ & 14 & $\mathrm{R}$ & B & Rooseboom et al., 1992 & 1 \\
\hline 458 & South Africa & Hoeks & Moordkuil & -33.7170 & 19.4326 & $\mathrm{~A}$ & 176 & 9 & $1950-1985$ & 35 & $\mathrm{R}$ & B & Rooseboom et al., 1992 & 1 \\
\hline 459 & South Africa & Mpapa & Jericho & -26.6452 & 30.4790 & A & 218 & 211 & $1966-1983$ & 17 & $\mathrm{R}$ & B & Rooseboom et al., 1992 & 1 \\
\hline 460 & South Africa & Umzinduzi & Henley & -29.6250 & 30.2469 & A & 238 & 42 & $1942-1987$ & 45 & $\mathrm{R}$ & B & Rooseboom et al., 1992 & 1 \\
\hline 461 & South Africa & Bethulie & Bethulie & -30.4804 & 25.9709 & $\mathrm{~A}$ & 255 & 455 & $1921-1979$ & 58 & $\mathrm{R}$ & B & Rooseboom et al., 1992 & 1 \\
\hline 463 & South Africa & Watervals & Buffelskloof & -24.9612 & 30.2594 & $\mathrm{~A}$ & 278 & 20 & $1972-1987$ & 15 & $\mathrm{R}$ & B & Rooseboom et al., 1992 & 1 \\
\hline 464 & South Africa & Koster & Koster & -25.7085 & 26.8985 & $\mathrm{~A}$ & 280 & 36 & $1964-1980$ & 16 & $\mathrm{R}$ & B & Rooseboom et al., 1992 & 1 \\
\hline 465 & South Africa & Dorp & Victoria-Wes & -30.0556 & 24.8004 & $\mathrm{C}$ & 280 & 53 & $1924-1954$ & 30 & $\mathrm{R}$ & B & Rooseboom et al., 1992 & 0 \\
\hline 466 & South Africa & Doring & Indwe & -31.5122 & 27.3311 & $\mathrm{~A}$ & 295 & 646 & $1969-1984$ & 15 & $\mathrm{R}$ & B & Rooseboom et al., 1992 & 1 \\
\hline 467 & South Africa & Apies & Bon Accord & -25.6283 & 28.1885 & A & 315 & 178 & $1925-1980$ & 55 & $\mathrm{R}$ & B & Rooseboom et al., 1992 & 1 \\
\hline 468 & South Africa & Krom & Churchill & -33.9936 & 24.4895 & A & 357 & 10 & $1943-1987$ & 44 & $\mathrm{R}$ & B & Rooseboom et al., 1992 & 1 \\
\hline 469 & South Africa & Schoonspruit & Rietspruit & -26.1622 & 29.2310 & $\mathrm{~A}$ & 375 & 65 & $1955-1989$ & 34 & $\mathrm{R}$ & B & Rooseboom et al., 1992 & 1 \\
\hline 470 & South Africa & Buffels & Bridle Drift & -32.9686 & 27.7380 & $\mathrm{~A}$ & 375 & 751 & $1968-1981$ & 13 & $\mathrm{R}$ & B & Rooseboom et al., 1992 & 0 \\
\hline 471 & South Africa & Mgeni & Camperdown & -29.7375 & 30.5401 & $\mathrm{C}$ & 376 & 84 & $1901-1923$ & 22 & $\mathrm{R}$ & B & Rooseboom et al., 1992 & 0 \\
\hline 472 & South Africa & Mdloti & Hazelmere & -29.5974 & 31.0301 & $\mathrm{~A}$ & 377 & 723 & $1975-1987$ & 12 & $\mathrm{R}$ & B & Rooseboom et al., 1992 & 1 \\
\hline 473 & South Africa & Nuy & Keerom & -33.5837 & 19.7072 & A & 378 & 88 & $1954-1981$ & 27 & $\mathrm{R}$ & B & Rooseboom et al., 1992 & 1 \\
\hline 474 & South Africa & Nahoon & Nahoon & -32.9106 & 27.8067 & $\mathrm{~B}$ & 474 & 115 & $1964-1981$ & 17 & $\mathrm{R}$ & B & Rooseboom et al., 1992 & 1 \\
\hline 475 & South Africa & Hennops & Rietvlei & -25.8865 & 28.2683 & $\mathrm{~A}$ & 479 & 40 & $1934-1977$ & 43 & $\mathrm{R}$ & B & Rooseboom et al., 1992 & 1 \\
\hline 476 & South Africa & Sterk & Doorndraai & -24.2812 & 28.7806 & $\mathrm{~A}$ & 479 & 98 & $1953-1979$ & 26 & $\mathrm{R}$ & B & Rooseboom et al., 1992 & 1 \\
\hline
\end{tabular}




\begin{tabular}{|l|c|c|c|c|c|c|c|c|c|c|c|c|c|}
\hline ID & Country & $\begin{array}{c}\text { River/Catchment } \\
\text { Name }\end{array}$ & $\begin{array}{c}\text { Measuring } \\
\text { location }\end{array}$ & Lat $\left({ }^{\circ}\right)$ & Lon $\left(^{\circ}\right)$ & $\begin{array}{c}\text { Coord. } \\
\text { Quality }\end{array}$ & A $\left(\mathbf{k m}^{2}\right)$ & $\begin{array}{c}\text { SY } \\
\left(\mathbf{t} / \mathbf{k m}^{2} / \mathbf{y}\right)\end{array}$ & MP & $\begin{array}{c}\text { MP } \\
\text { length } \\
(\mathbf{y})\end{array}$ & $\begin{array}{c}\text { Type } \\
\text { Quality }\end{array}$ & Reference \\
\hline
\end{tabular}

\begin{tabular}{|c|c|c|c|c|c|c|c|c|c|c|c|c|c|c|}
\hline 477 & South Africa & Hex & Olifantsnek & -25.7939 & 27.2539 & A & 492 & 105 & $1928-1988$ & 60 & $\mathrm{R}$ & B & Rooseboom et al., 1992 & 1 \\
\hline 478 & South Africa & Leeu & Armenia & -29.3497 & 27.1359 & $\mathrm{~A}$ & 529 & 32 & $1951-1987$ & 36 & $\mathrm{R}$ & $\mathrm{B}$ & Rooseboom et al., 1992 & 1 \\
\hline 479 & South Africa & Nuwejaars & Nuwejaars & -33.2933 & 26.1219 & A & 531 & 4 & $1958-1981$ & 23 & $\mathrm{R}$ & B & Rooseboom et al., 1992 & 1 \\
\hline 480 & South Africa & Usutu & Westoe & -26.5002 & 30.6196 & $\mathrm{~A}$ & 531 & 5 & $1968-1980$ & 12 & $\mathrm{R}$ & $\mathrm{B}$ & Rooseboom et al., 1992 & 1 \\
\hline 481 & South Africa & Brak & Bellair & -33.7155 & 20.5930 & $\mathrm{~A}$ & 558 & 34 & $1920-1981$ & 61 & $\mathrm{R}$ & B & Rooseboom et al., 1992 & 1 \\
\hline 482 & South Africa & Hex & Bospoort & -25.5724 & 27.3307 & $\mathrm{C}$ & 600 & 63 & $1953-1969$ & 16 & $\mathrm{R}$ & $\mathrm{B}$ & Rooseboom et al., 1992 & 0 \\
\hline 483 & South Africa & Modder & Rustfontein & -29.2696 & 26.6157 & B & 600 & 283 & $1955-1981$ & 26 & $\mathrm{R}$ & B & Rooseboom et al., 1992 & 0 \\
\hline 484 & South Africa & Buffeljags & Buffeljags & -34.0233 & 20.5449 & $\mathrm{~A}$ & 601 & 7 & $1966-1983$ & 17 & $\mathrm{R}$ & $\mathrm{B}$ & Rooseboom et al., 1992 & 1 \\
\hline 486 & South Africa & Marico & Kromellenboog & -25.4408 & 26.3451 & $\mathrm{~A}$ & 606 & 132 & $1955-1983$ & 28 & $\mathrm{R}$ & $\mathrm{B}$ & Rooseboom et al., 1992 & 0 \\
\hline 487 & South Africa & Pienaars & Roodeplaat & -25.6199 & 28.3763 & A & 684 & 105 & $1959-1980$ & 21 & $\mathrm{R}$ & B & Rooseboom et al., 1992 & 1 \\
\hline 488 & South Africa & Elands & Lindleyspoort & -25.4982 & 26.6918 & $\mathrm{~A}$ & 705 & 83 & $1938-1980$ & 42 & $\mathrm{R}$ & $\mathrm{B}$ & Rooseboom et al., 1992 & 1 \\
\hline 489 & South Africa & Umgeni & Albert Falls & -29.4304 & 30.4228 & B & 716 & 31 & $1974-1983$ & 9 & $\mathrm{R}$ & B & Rooseboom et al., 1992 & 0 \\
\hline 490 & South Africa & Hluhluwe & Hluhluwe & -28.1163 & 32.1873 & $\mathrm{~A}$ & 734 & 137 & $1964-1985$ & 21 & $\mathrm{R}$ & $\mathrm{B}$ & Rooseboom et al., 1992 & 1 \\
\hline 491 & South Africa & Olifants & Bulshoek & -31.9951 & 18.7879 & A & 736 & 17 & $1922-1980$ & 58 & $\mathrm{R}$ & B & Rooseboom et al., 1992 & 0 \\
\hline 492 & South Africa & Boesmans & Wagendrift & -29.0444 & 29.8521 & $\mathrm{~A}$ & 744 & 91 & $1963-1983$ & 20 & $\mathrm{R}$ & $\mathrm{B}$ & Rooseboom et al., 1992 & 1 \\
\hline 493 & South Africa & Mlazi & Shongweni & -29.8575 & 30.7203 & A & 750 & 231 & $1927-1987$ & 60 & $\mathrm{R}$ & B & Rooseboom et al., 1992 & 1 \\
\hline 495 & South Africa & Tugele & Spioenkop & -28.6815 & 29.5012 & $\mathrm{~B}$ & 774 & 426 & $1972-1986$ & 14 & $\mathrm{R}$ & B & Rooseboom et al., 1992 & 0 \\
\hline 496 & South Africa & Ngagane & Chelmsford & -27.9682 & 29.9344 & $\mathrm{~A}$ & 830 & 160 & $1961-1983$ & 22 & $\mathrm{R}$ & $\mathrm{B}$ & Rooseboom et al., 1992 & 1 \\
\hline 497 & South Africa & Nzhelele & Nzhelele & -22.7372 & 30.1024 & A & 842 & 119 & $1948-1979$ & 31 & $\mathrm{R}$ & B & Rooseboom et al., 1992 & 1 \\
\hline 498 & South Africa & Buffels & Laing & -32.9556 & 27.5005 & $\mathrm{~A}$ & 862 & 75 & $1950-1981$ & 31 & $\mathrm{R}$ & $\mathrm{B}$ & Rooseboom et al., 1992 & 1 \\
\hline 499 & South Africa & Mtata & Mtata & -31.5479 & 28.7351 & $\mathrm{~A}$ & 868 & 89 & $1977-1987$ & 10 & $\mathrm{R}$ & B & Rooseboom et al., 1992 & 1 \\
\hline 500 & South Africa & Loop & Klipdrift & -34.1273 & 24.5660 & $\mathrm{~B}$ & 881 & 38 & $1918-1977$ & 59 & $\mathrm{R}$ & $\mathrm{B}$ & Rooseboom et al., 1992 & 0 \\
\hline 501 & South Africa & Kaffir & Tierpoort & -29.4108 & 26.1487 & A & 922 & 113 & $1922-1979$ & 57 & $\mathrm{R}$ & B & Rooseboom et al., 1992 & 1 \\
\hline 502 & South Africa & Umgeni & Midmar & -29.5153 & 30.1759 & $\mathrm{~A}$ & 928 & 10 & $1965-1983$ & 18 & $\mathrm{R}$ & $\mathrm{B}$ & Rooseboom et al., 1992 & 1 \\
\hline 503 & South Africa & Elands & Rust de Winter & -25.2372 & 28.5141 & $\mathrm{~A}$ & 1147 & 33 & $1934-1977$ & 43 & $\mathrm{R}$ & $\mathrm{B}$ & Rooseboom et al., 1992 & 1 \\
\hline 504 & South Africa & Marico & Klein Maricoprt & -25.5246 & 26.1419 & $\mathrm{~A}$ & 1180 & 21 & $1934-1983$ & 49 & $\mathrm{R}$ & $\mathrm{B}$ & Rooseboom et al., 1992 & 1 \\
\hline 505 & South Africa & Marico & Marico-Bosveld & -25.4682 & 26.3965 & A & 1219 & 52 & $1933-1977$ & 44 & $\mathrm{R}$ & B & Rooseboom et al., 1992 & 1 \\
\hline 506 & South Africa & Bronkhorst & Bronkhorstspruit & -25.8886 & 28.7222 & $\mathrm{~A}$ & 1263 & 48 & $1948-1983$ & 35 & $\mathrm{R}$ & $\mathrm{B}$ & Rooseboom et al., 1992 & 1 \\
\hline 507 & South Africa & Bierspruit & Bierspruit & -24.9180 & 27.1387 & $\mathrm{~A}$ & 1330 & 20 & $1960-1980$ & 20 & $\mathrm{R}$ & $\mathrm{B}$ & Rooseboom et al., 1992 & 1 \\
\hline 508 & South Africa & Mooi & Klerkskraal & -26.2311 & 27.1487 & B & 1335 & 17 & $1969-1982$ & 13 & $\mathrm{R}$ & B & Rooseboom et al., 1992 & 1 \\
\hline
\end{tabular}




\begin{tabular}{|c|c|c|c|c|c|c|c|c|c|c|c|c|c|}
\hline ID & Country & $\begin{array}{c}\text { River/Catchment } \\
\text { Name }\end{array}$ & $\begin{array}{c}\text { Measuring } \\
\text { location }\end{array}$ & Lat $\left(^{\circ}\right)$ & Lon $\left(^{\circ}\right)$ & $\begin{array}{c}\text { Coord. } \\
\text { Quality }\end{array}$ & A $\left(\mathbf{k m}^{2}\right)$ & $\begin{array}{c}\text { SY } \\
\left(\mathbf{t} / \mathrm{km}^{2} / \mathbf{y}\right)\end{array}$ & MP & $\begin{array}{c}\text { MP } \\
\text { length } \\
(\mathbf{y})\end{array}$ & $\begin{array}{c}\text { Type } \\
\text { Quality }\end{array}$ & $\begin{array}{c}\text { Data } \\
\text { Reference }\end{array}$ \\
\hline
\end{tabular}

\begin{tabular}{|c|c|c|c|c|c|c|c|c|c|c|c|c|c|c|}
\hline 509 & South Africa & Van Wyksvlei & Van Wyksvlei & -30.3807 & 21.8107 & $\mathrm{~A}$ & 1339 & 26 & $1884-1979$ & 95 & $\mathrm{R}$ & $\mathrm{B}$ & Rooseboom et al., 1992 & 1 \\
\hline 510 & South Africa & Wit Kei & Xonxa & -31.8167 & 27.1500 & A & 1487 & 881 & $1974-1986$ & 12 & $\mathrm{R}$ & $\mathrm{B}$ & Rooseboom et al., 1992 & 1 \\
\hline 511 & South Africa & Kammanassie & Kammanassie & -33.6492 & 22.4121 & $\mathrm{~A}$ & 1505 & 54 & $1923-1981$ & 58 & $\mathrm{R}$ & $\mathrm{B}$ & Rooseboom et al., 1992 & 1 \\
\hline 512 & South Africa & Komati & Nooitgedacht & -25.5197 & 28.0325 & $\mathrm{~B}$ & 1569 & 30 & $1962-1983$ & 21 & $\mathrm{R}$ & $\mathrm{B}$ & Rooseboom et al., 1992 & 0 \\
\hline 514 & South Africa & Mooi & Boskop & -26.5722 & 27.1108 & $\mathrm{C}$ & 1952 & 8 & $1959-1981$ & 22 & $\mathrm{R}$ & $\mathrm{B}$ & Rooseboom et al., 1992 & 0 \\
\hline 515 & South Africa & Olifants & Clanwilliam & -32.2023 & 18.8857 & $\mathrm{~A}$ & 2033 & 134 & $1935-1980$ & 45 & $\mathrm{R}$ & $\mathrm{B}$ & Rooseboom et al., 1992 & 1 \\
\hline 516 & South Africa & Leeu & Leeu gamka & -32.6901 & 23.1000 & $\mathrm{C}$ & 2088 & 140 & $1959-1981$ & 22 & $\mathrm{R}$ & $\mathrm{B}$ & Rooseboom et al., 1992 & 0 \\
\hline 517 & South Africa & Renoster & Koppies & -27.2449 & 27.6822 & $\mathrm{~A}$ & 2147 & 136 & $1911-1978$ & 67 & $\mathrm{R}$ & $\mathrm{B}$ & Rooseboom et al., 1992 & 1 \\
\hline 518 & South Africa & Sand & Allemanskraal & -28.2947 & 27.1326 & $\mathrm{~B}$ & 2655 & 373 & $1960-1989$ & 29 & $\mathrm{R}$ & $\mathrm{B}$ & Rooseboom et al., 1992 & 1 \\
\hline 519 & South Africa & Modder & Krugersdrift & -28.8869 & 25.9628 & $\mathrm{~B}$ & 3355 & 157 & $1970-1989$ & 19 & $\mathrm{R}$ & $\mathrm{B}$ & Rooseboom et al., 1992 & 0 \\
\hline 520 & South Africa & Tarka & Lake Arthur & -32.2112 & 25.8127 & $\mathrm{~A}$ & 3450 & 521 & $1924-1985$ & 61 & $\mathrm{R}$ & $\mathrm{B}$ & Rooseboom et al., 1992 & 0 \\
\hline 521 & South Africa & Sondags & $\begin{array}{c}\text { Van } \\
\text { Rhyneveldspas }\end{array}$ & -32.2236 & 24.5216 & $\mathrm{~A}$ & 3544 & 210 & $1925-1978$ & 53 & $\mathrm{R}$ & $\mathrm{B}$ & Rooseboom et al., 1992 & 1 \\
\hline 522 & South Africa & Limpopo & Hartebeespoort & -25.7506 & 27.8613 & $\mathrm{~A}$ & 3633 & 256 & $1923-1979$ & 50 & $\mathrm{R}$ & $\mathrm{B}$ & Rooseboom et al., 1992 & 1 \\
\hline 523 & South Africa & Koega & Paul Sauer & -33.7392 & 24.5888 & $\mathrm{~A}$ & 3887 & 18 & $1969-1986$ & 17 & $\mathrm{R}$ & B & Rooseboom et al., 1992 & 1 \\
\hline 524 & South Africa & Vet & Erfenis & -28.5127 & 26.7767 & $\mathrm{~B}$ & 4000 & 173 & $1959-1987$ & 28 & $\mathrm{R}$ & $\mathrm{B}$ & Rooseboom et al., 1992 & 1 \\
\hline 525 & South Africa & Buffels & Floriskraal & -33.2815 & 20.9891 & A & 4001 & 169 & $1957-1981$ & 24 & $\mathrm{R}$ & B & Rooseboom et al., 1992 & 1 \\
\hline 527 & South Africa & Mogol & Hans Strydom & -23.9771 & 27.7252 & $\mathrm{~A}$ & 4319 & 11 & $1975-1988$ & 13 & $\mathrm{R}$ & B & Rooseboom et al., 1992 & 1 \\
\hline 528 & South Africa & Pienaars & Klipvoor & -25.1478 & 27.8316 & $\mathrm{~B}$ & 4585 & 14 & $1970-1987$ & 17 & $\mathrm{R}$ & $\mathrm{B}$ & Rooseboom et al., 1992 & 0 \\
\hline 529 & South Africa & Olifants & Stompdrift & -33.5125 & 22.5856 & $\mathrm{~B}$ & 5235 & 58 & $1965-1981$ & 16 & $\mathrm{R}$ & B & Rooseboom et al., 1992 & 1 \\
\hline 530 & South Africa & Olifants & Loskop & -25.4299 & 29.3219 & $\mathrm{C}$ & 5820 & 58 & $1939-1977$ & 38 & $\mathrm{R}$ & $\mathrm{B}$ & Rooseboom et al., 1992 & 0 \\
\hline 531 & South Africa & Pongola & Pongolapoort & -27.4200 & 32.0792 & $\mathrm{~A}$ & 7831 & 446 & $1973-1984$ & 11 & $\mathrm{R}$ & $\mathrm{B}$ & Rooseboom et al., 1992 & 1 \\
\hline 532 & South Africa & Vis & Elandsdrift & -32.5306 & 25.7610 & $\mathrm{~B}$ & 8042 & 27 & $1973-1981$ & 8 & $\mathrm{R}$ & $\mathrm{B}$ & Rooseboom et al., 1992 & 0 \\
\hline 533 & South Africa & Riet & Kalkfontein & -29.5107 & 25.2570 & $\mathrm{~B}$ & 8647 & 122 & $1938-1979$ & 41 & $\mathrm{R}$ & $\mathrm{B}$ & Rooseboom et al., 1992 & 1 \\
\hline 534 & South Africa & Mogalakwena & Glen Alpine & -23.2058 & 28.6886 & $\mathrm{~B}$ & 10713 & 10 & $1967-1979$ & 12 & $\mathrm{R}$ & $\mathrm{B}$ & Rooseboom et al., 1992 & 1 \\
\hline 535 & South Africa & Sondags & Lake Mentz & -33.1807 & 25.1508 & $\mathrm{~B}$ & 12987 & 271 & $1922-1978$ & 56 & $\mathrm{R}$ & $\mathrm{B}$ & Rooseboom et al., 1992 & 0 \\
\hline 536 & South Africa & Ongers & Smartt & -30.6258 & 23.2954 & $\mathrm{~B}$ & 13114 & 4 & $1912-1980$ & 68 & $\mathrm{R}$ & $\mathrm{B}$ & Rooseboom et al., 1992 & 1 \\
\hline 537 & South Africa & Gamka & Gamkapoort & -33.2960 & 21.6330 & $\mathrm{~B}$ & 17076 & 35 & $1969-1981$ & 12 & $\mathrm{R}$ & $\mathrm{B}$ & Rooseboom et al., 1992 & 1 \\
\hline 538 & South Africa & Oranje & Hendrik Verwoerd & -30.6237 & 25.5020 & $\mathrm{~B}$ & 67845 & 352 & 1971 - 1979 & 8 & $\mathrm{R}$ & $\mathrm{B}$ & Rooseboom et al., 1992 & 1 \\
\hline 539 & South Africa & Bloed & Rooikraal & -25.2945 & 29.6503 & $\mathrm{~A}$ & 168 & 302 & $1921-1968$ & 48 & $\mathrm{R}$ & $\mathrm{B}$ & Rooseboom, 1978 & 1 \\
\hline 540 & South Africa & Witspruit & Egmont Dam & -30.0493 & 27.0360 & $\mathrm{~A}$ & 326 & 120 & $1937-1955$ & 19 & $\mathrm{R}$ & $\mathrm{B}$ & Rooseboom, 1978 & 1 \\
\hline
\end{tabular}




\begin{tabular}{|c|c|c|c|c|c|c|c|c|c|c|c|c|c|c|}
\hline ID & Country & $\begin{array}{c}\text { River/Catchment } \\
\text { Name }\end{array}$ & $\begin{array}{l}\text { Measuring } \\
\text { location }\end{array}$ & Lat $\left(^{\circ}\right)$ & Lon $\left(^{\circ}\right)$ & $\begin{array}{l}\text { Coord. } \\
\text { Quality }\end{array}$ & $\mathbf{A}\left(\mathbf{k m}^{2}\right)$ & $\underset{\left(\mathbf{t} / \mathbf{k m}^{2} / \mathbf{y}\right)}{\mathbf{S Y}}$ & MP & $\begin{array}{c}\text { MP } \\
\text { length } \\
(\mathbf{y})\end{array}$ & Type & $\begin{array}{c}\text { Data } \\
\text { Quality }\end{array}$ & Reference & GIS \\
\hline
\end{tabular}

\begin{tabular}{|c|c|c|c|c|c|c|c|c|c|c|c|c|c|c|}
\hline 541 & South Africa & Mzimkulwana & Gilbert Eyles & -30.7189 & 30.1511 & A & 409 & 89 & $1951-1966$ & 16 & $\mathrm{R}$ & B & Rooseboom, 1978 & 1 \\
\hline 542 & South Africa & Kat & Upsher & -32.5703 & 26.6845 & A & 554 & 499 & $1931-1948$ & 18 & GS & B & Rooseboom, 1978 & 1 \\
\hline 543 & South Africa & Klein Vis & Buffelsfontein & -26.8986 & 26.8167 & B & 995 & 589 & $1931-1939$ & 9 & GS & B & Rooseboom, 1978 & 1 \\
\hline 544 & South Africa & Modder & Sannaspos & -29.1520 & 26.5386 & $\mathrm{~B}$ & 1650 & 304 & $1935-1943$ & 9 & GS & $\mathrm{B}$ & Rooseboom, 1978 & 1 \\
\hline 545 & South Africa & Stormbergspruit & Burgersdorp & -31.0107 & 26.3282 & A & 2370 & 762 & $1935-1948$ & 14 & GS & B & Rooseboom, 1978 & 1 \\
\hline 546 & South Africa & Tarka & Kommandodrif & -32.0867 & 26.0366 & A & 3528 & 86 & $1956-1966$ & 11 & $\mathrm{R}$ & $\mathrm{B}$ & Rooseboom, 1978 & 1 \\
\hline 547 & South Africa & Olifants & Doornpoort & -25.8623 & 29.3049 & A & 3618 & 3 & $1925-1973$ & 49 & $\mathrm{R}$ & B & Rooseboom, 1978 & 1 \\
\hline 548 & South Africa & Tugela/Tugela & Colenso & -28.7367 & 29.8210 & A & 4200 & 463 & $1950-1959$ & 10 & GS & B & Rooseboom, 1978 & 1 \\
\hline 549 & South Africa & Groot Brak & Grassridge & -31.7547 & 25.4695 & A & 4483 & 223 & $1924-1966$ & 43 & $\mathrm{R}$ & B & Rooseboom, 1978 & 1 \\
\hline 550 & South Africa & Pongola & Intuembi & -27.9161 & 30.6633 & $\mathrm{C}$ & 7122 & 114 & $1932-1938$ & 7 & GS & B & Rooseboom, 1978 & 0 \\
\hline 551 & South Africa & Tugela/Buffels & Vant's Drift & -28.2348 & 30.5008 & A & 7930 & 559 & $1930-1932$ & 3 & GS & B & Rooseboom, 1978 & 1 \\
\hline 552 & South Africa & Vaal & Standerton & -26.9596 & 29.2443 & A & 8254 & 193 & $1929-1940$ & 12 & GS & B & Rooseboom, 1978 & 1 \\
\hline 553 & South Africa & Harts & Schweizer-Reneke & -27.1624 & 25.3457 & A & 9251 & 7 & $1934-1956$ & 23 & GS & B & Rooseboom, 1978 & 1 \\
\hline 554 & South Africa & Riet & Leeuwkraal & -24.9373 & 29.8174 & B & 10277 & 100 & $1929-1938$ & 10 & GS & B & Rooseboom, 1978 & 0 \\
\hline 555 & South Africa & Sondags & Jansenville & -32.9491 & 24.6643 & B & 11560 & 136 & $1930-1948$ & 19 & GS & B & Rooseboom, 1978 & 1 \\
\hline 556 & South Africa & Oranje & $\begin{array}{c}\text { Aliwal- } \\
\text { Oranjedraai } \\
\end{array}$ & -30.3359 & 27.3547 & B & 12321 & 540 & $1929-1969$ & 41 & GS & B & Rooseboom, 1978 & 0 \\
\hline 557 & South Africa & Caledon & Jammersdrift & $\mid-29.7190$ & 26.9807 & B & 13320 & 890 & $1929-1943$ & 15 & GS & B & Rooseboom, 1978 & 1 \\
\hline 558 & South Africa & Modder & Paardeberg & -28.9825 & 25.0931 & $\mathrm{C}$ & 14812 & 95 & $1939-1948$ & 10 & GS & B & Rooseboom, 1978 & 0 \\
\hline 559 & South Africa & Oranje & Oranjedraai & -30.3363 & 27.3541 & $\mathrm{~B}$ & 24882 & 402 & $1964-1971$ & 8 & GS & $\mathrm{B}$ & Rooseboom, 1978 & 1 \\
\hline 560 & South Africa & Oranje & $\begin{array}{l}\text { Oranjerivierbrug- } \\
\text { Bethulie }\end{array}$ & -30.5346 & 25.9677 & $\mathrm{C}$ & 29316 & 418 & $1929-1952$ & 24 & GS & $\mathrm{B}$ & Rooseboom, 1978 & 0 \\
\hline 561 & South Africa & Vaal & Vaaldam & -26.8975 & 28.1405 & $\mathrm{~B}$ & 37110 & 125 & $1938-1966$ & 29 & $\mathrm{R}$ & $\mathrm{B}$ & Rooseboom, 1978 & 1 \\
\hline 562 & South Africa & Hartbees & Rooiberg & -29.4106 & 21.2077 & B & 72208 & 6 & $1935-1960$ & 26 & $\mathrm{R}$ & B & Rooseboom, 1978 & 1 \\
\hline 563 & South Africa & Jakkalsrivier & near Bot River & -34.1998 & 19.1576 & $\mathrm{~A}$ & 0.18 & 1.6 & N.A. & N.A. & GS & $\mathrm{A}$ & Scott et al., 1998 & 1 \\
\hline 564 & South Africa & Biesievlei & Jonkershoek & -33.9770 & 18.9480 & $\mathrm{~A}$ & 0.27 & 1.6 & N.A. & N.A. & GS & A & Scott et al., 1998 & 1 \\
\hline 565 & South Africa & Lambrechtbos & Jonkershoek & -33.9682 & 18.9417 & A & 0.66 & 15.6 & N.A. & N.A. & GS & A & Scott et al., 1998 & 1 \\
\hline 566 & South Africa & Swartboskloof & Jonkershoek & -33.9943 & 18.9534 & A & 1.8 & 42.2 & N.A. & N.A. & $\begin{array}{l}\text { GS } \\
\text { (TL) }\end{array}$ & A & Scott et al., 1998 & 1 \\
\hline 567 & South Africa & Bosboukloof & Jonkershoek & -33.9602 & 18.9384 & A & 2.0 & 208 & N.A. & N.A. & $\begin{array}{l}\text { GS } \\
\text { (TL) }\end{array}$ & A & Scott et al., 1998 & 1 \\
\hline 568 & South Africa & Langrivier & Jonkershoek & -33.9852 & 18.9725 & A & 2.5 & 34.6 & N.A. & 11 & GS & A & Scott et al., 1998 & 1 \\
\hline 569 & South Africa & Bakkerskloof & Zachariahoek & -33.7615 & 19.0558 & A & 3.6 & 16.6 & N.A. & N.A. & $\begin{array}{l}\text { GS } \\
\text { (TL) }\end{array}$ & A & Scott et al., 1998 & 1 \\
\hline 570 & Sudan & Dinder River & Gawisi & 13.3286 & 34.0987 & B & 16000 & 75 & $1993-1996$ & 4 & GS & $\mathrm{U}$ & $\begin{array}{c}\text { Billi and el Badri Ali, } \\
2010\end{array}$ & 0 \\
\hline
\end{tabular}




\begin{tabular}{|c|c|c|c|c|c|c|c|c|c|c|c|c|c|c|}
\hline ID & Country & $\begin{array}{c}\text { River/Catchment } \\
\text { Name }\end{array}$ & $\begin{array}{l}\text { Measuring } \\
\text { location }\end{array}$ & Lat $\left({ }^{\circ}\right)$ & Lon $\left(^{\circ}\right)$ & $\begin{array}{l}\text { Coord. } \\
\text { Quality }\end{array}$ & $A\left(\mathbf{k m}^{2}\right)$ & $\underset{\left(\mathbf{t} / \mathbf{k m}^{2} / \mathbf{y}\right)}{\mathbf{S Y}}$ & MP & $\begin{array}{c}\text { MP } \\
\text { length } \\
(\mathbf{y})\end{array}$ & Type & $\begin{array}{l}\text { Data } \\
\text { Quality }\end{array}$ & Reference & GIS \\
\hline & & & & & & & & & & & & & & \\
\hline 571 & Sudan & Rahad & Hawata & 13.4130 & 34.6168 & $\mathrm{C}$ & 16049 & 81 & $1993-1996$ & 4 & GS & $\mathrm{U}$ & $\begin{array}{l}\text { Billi and el Badri Ali, } \\
2010\end{array}$ & 0 \\
\hline 572 & Sudan & Blue Nile & El Diem & 11.2500 & 34.8238 & B & 198364 & 489 & 1993 & 1 & GS & $\mathrm{U}$ & $\begin{array}{l}\text { Billi and el Badri Ali, } \\
2010\end{array}$ & 0 \\
\hline 573 & Sudan & Blue Nile & Roseires & 11.7467 & 34.4018 & B & 209895 & 667 & $1964-1990$ & 27 & GS & $\mathrm{U}$ & $\begin{array}{c}\text { Billi and el Badri Ali, } \\
2010 \\
\end{array}$ & 0 \\
\hline 574 & Sudan & Blue Nile & Sennar & 13.5417 & 33.6383 & B & 277286 & 339 & $1993-1996$ & 4 & GS & $\mathrm{U}$ & $\begin{array}{c}\text { Billi and el Badri Ali, } \\
2010 \\
\end{array}$ & 0 \\
\hline 575 & Sudan & Blue Nile & Khartoum & 15.5714 & 32.5933 & B & 324859 & 708 & $1964-1990$ & 27 & GS & $\mathrm{U}$ & $\begin{array}{l}\text { Billi and el Badri Ali, } \\
2010\end{array}$ & 1 \\
\hline 576 & Sudan & Nile & Wadi Halfa & 21.7920 & 31.3709 & B & 2600000 & 38 & N.A. & N.A. & GS & $\mathrm{U}$ & $\begin{array}{l}\text { Dedkov and Mozzherin, } \\
1984\end{array}$ & 1 \\
\hline 577 & Sudan & Atbara & Khashm el Girba & 14.8721 & 35.8968 & B & 20000 & 3422 & $1964-1976$ & 13 & $\mathrm{R}$ & $\mathrm{U}$ & FAO, 2008 & 0 \\
\hline 578 & Sudan & Gash & Kassala & 15.4398 & 36.3918 & B & 24642 & 365.2 & N.A. & 2 & GS & $\mathrm{U}$ & Nyssen et al., 2004 & 1 \\
\hline 579 & Sudan & Atbara & outlet & 17.6676 & 34.0242 & $\mathrm{~B}$ & 68800 & 203.5 & N.A. & N.A. & GS & $\mathrm{U}$ & Nyssen et al., 2004 & 0 \\
\hline 580 & Tanzania & Morogoro & Morogoro & -6.8218 & 37.6688 & $\mathrm{~B}$ & 19 & 390 & N.A. & 3 & GS & $\mathrm{U}$ & $\begin{array}{c}\text { Dedkov and Mozzherin, } \\
1984 \\
\end{array}$ & 1 \\
\hline 581 & Tanzania & Rufiji & Stiegler's Gorge & -7.7989 & 37.8632 & $\mathrm{~B}$ & 156600 & 106 & $1954-1970$ & 17 & GS & $\mathrm{U}$ & FAO, 2008 & 1 \\
\hline 582 & Tanzania & Rufiji & near outlet & -7.8059 & 39.3158 & B & 180000 & 144.4 & N.A. & N.A. & GS & $\mathrm{U}$ & $\begin{array}{l}\text { Milliman and Fansworth, } \\
2011\end{array}$ & 1 \\
\hline 583 & Tanzania & & Igurubi & -3.9993 & 33.7066 & A & 1.2 & 1078.6 & $1959-1978$ & 19 & $\mathrm{R}$ & $\mathrm{C}$ & Ndomba, 2011 & 1 \\
\hline 584 & Tanzania & & Mbola & -4.8776 & 32.7211 & $\mathrm{C}$ & 6.4 & 635.4 & $1972-1978$ & 6 & $\mathrm{R}$ & $\mathrm{C}$ & Ndomba, 2011 & 0 \\
\hline 585 & Tanzania & & Ulaya & -4.3992 & 33.4503 & A & 8.3 & 155.7 & $1947-1978$ & 31 & $\mathrm{R}$ & $\mathrm{C}$ & Ndomba, 2011 & 1 \\
\hline 586 & Tanzania & & Malolo & -4.1044 & 32.8513 & $\mathrm{~A}$ & 15 & 119.3 & $1962-1975$ & 13 & $\mathrm{R}$ & $\mathrm{C}$ & Ndomba, 2011 & 1 \\
\hline 587 & Tanzania & & Tura & -5.5284 & 33.8327 & A & 105 & 109.5 & $1948-1978$ & 30 & $\mathrm{R}$ & $\mathrm{C}$ & Ndomba, 2011 & 1 \\
\hline 588 & Tanzania & & Bulenya hills & -4.2889 & 33.7873 & A & 194 & 51.4 & $1961-1978$ & 17 & $\mathrm{R}$ & $\mathrm{C}$ & Ndomba, 2011 & 1 \\
\hline 589 & Tanzania & Ngonya & $\begin{array}{c}\text { outlet in lake } \\
\text { Tanganyika }\end{array}$ & -4.6260 & 29.6420 & A & 7.0 & 3131.6 & Nov 1997 - Oct 1998 & 1 & GS & $\mathrm{C}$ & $\begin{array}{c}\text { Nkotagu en Mbwano, } \\
2000\end{array}$ & 1 \\
\hline 590 & Tanzania & & Imagi & -6.2061 & 35.7552 & A & 1.5 & 701.3 & $1930-1971$ & 42 & $\mathrm{R}$ & B & Rapp et al., 1972 & 1 \\
\hline 591 & Tanzania & & Msalatu & -6.2038 & 35.7720 & $\mathrm{~B}$ & 8.7 & 503.3 & $1944-1971$ & 28 & $\mathrm{R}$ & B & Rapp et al., 1972 & 1 \\
\hline 592 & Tanzania & & Kisongo & -3.3391 & 36.5778 & $\mathrm{~B}$ & 9.3 & 736.7 & $1960-1971$ & 12 & $\mathrm{R}$ & B & Rapp et al., 1972 & 0 \\
\hline 593 & Tanzania & & Matambulu & -6.2856 & 35.7403 & $\mathrm{~A}$ & 18 & 1009.8 & $1962-1971$ & 10 & $\mathrm{R}$ & B & Rapp et al., 1972 & 1 \\
\hline 594 & Tanzania & & Ikowa & -6.1886 & 36.2243 & A & 640 & 393.6 & $1957-1969$ & 13 & $\mathrm{R}$ & B & Rapp et al., 1972 & 1 \\
\hline 595 & Tanzania & Kalambo & Kalambo village & -8.5924 & 31.2490 & A & 2575 & 3.8 & $\begin{array}{c}1 \text { Oct } 1998-30 \text { Sept } \\
1999\end{array}$ & 1 & GS & $\mathrm{C}$ & Sichingabula, 2000 & 0 \\
\hline 596 & Tanzania & Lufubu & Kabyolwe village & -8.5806 & 31.7134 & $\mathrm{C}$ & 7047 & 7.9 & $\begin{array}{c}1 \text { Oct } 1998-30 \text { Sept } \\
1999\end{array}$ & 1 & GS & $\mathrm{C}$ & Sichingabula, 2000 & 0 \\
\hline
\end{tabular}




\begin{tabular}{|c|c|c|c|c|c|c|c|c|c|c|c|c|c|c|}
\hline ID & Country & $\begin{array}{c}\text { River/Catchment } \\
\text { Name }\end{array}$ & $\begin{array}{l}\text { Measuring } \\
\text { location }\end{array}$ & Lat $\left({ }^{\circ}\right)$ & Lon $\left(^{\circ}\right)$ & $\begin{array}{l}\text { Coord. } \\
\text { Quality }\end{array}$ & $A\left(\mathbf{k m}^{2}\right)$ & $\underset{\left(\mathbf{t} / \mathbf{k m}^{2} / \mathbf{y}\right)}{\mathbf{S Y}}$ & MP & $\begin{array}{c}\text { MP } \\
\text { length } \\
(\mathbf{y})\end{array}$ & Type & $\begin{array}{l}\text { Data } \\
\text { Quality }\end{array}$ & Reference & GIS \\
\hline 597 & Togo & Mono & near outlet & 6.2565 & 1.8055 & B & 29000 & 55.2 & N.A. & N.A. & GS & $\mathrm{U}$ & $\begin{array}{l}\text { Milliman and Fansworth, } \\
2011\end{array}$ & 1 \\
\hline 598 & Tunesia & & El Melah & 36.4648 & 10.6539 & A & 0.85 & 707.2 & $1994-1999$ & 5 & $\mathrm{R}$ & $\mathrm{B}$ & Boufaroua et al., 2006 & 1 \\
\hline 599 & Tunesia & & M'Richet el Anse & 36.0932 & 9.5948 & $\mathrm{~A}$ & 1.6 & 1028.6 & $1993-2003$ & 10 & $\mathrm{R}$ & $\mathrm{B}$ & Boufaroua et al., 2006 & 0 \\
\hline 600 & Tunesia & & Fidh Ben Naceur & 35.7233 & 9.5903 & $\mathrm{~A}$ & 1.7 & 1272 & $1993-2001$ & 8 & $\mathrm{R}$ & B & Boufaroua et al., 2006 & 1 \\
\hline 601 & Tunesia & & Kamech & 36.8717 & 10.8689 & $\mathrm{~A}$ & 2.5 & 2121.6 & $1994-2006$ & 12 & $\mathrm{R}$ & B & Boufaroua et al., 2006 & 1 \\
\hline 602 & Tunesia & & Saadine & 36.1152 & 9.9439 & $\mathrm{~A}$ & 2.7 & 2581.1 & $1994-1999$ & 5 & $\mathrm{R}$ & $\mathrm{B}$ & Boufaroua et al., 2006 & 1 \\
\hline 603 & Tunesia & & Abdessadock & 35.6827 & 9.2466 & $\mathrm{~A}$ & 3.1 & 1374.2 & $1993-2000$ & 7 & $\mathrm{R}$ & B & Boufaroua et al., 2006 & 1 \\
\hline 604 & Tunesia & & Dékikira & 35.8844 & 9.6814 & $\mathrm{~A}$ & 3.1 & 1660.7 & $1993-2006$ & 13 & $\mathrm{R}$ & $\mathrm{B}$ & Boufaroua et al., 2006 & 0 \\
\hline 605 & Tunesia & & Sbahia 1 & 36.4953 & 10.2086 & $\mathrm{~A}$ & 3.2 & 1359.7 & $1993-2006$ & 13 & $\mathrm{R}$ & $\mathrm{B}$ & Boufaroua et al., 2006 & 1 \\
\hline 606 & Tunesia & & El Amadi & 36.1756 & 8.7842 & $\mathrm{~A}$ & 3.3 & 733.1 & $1999-2004$ & 5 & $\mathrm{R}$ & B & Boufaroua et al., 2006 & 1 \\
\hline 607 & Tunesia & & Es Sénéga & 35.4883 & 9.1049 & A & 3.6 & 1465 & $1993-2002$ & 9 & $\mathrm{R}$ & $\mathrm{B}$ & Boufaroua et al., 2006 & 1 \\
\hline 608 & Tunesia & & Sadine1 & 35.7993 & 9.0662 & $\mathrm{~B}$ & 3.8 & 1397.3 & $1992-2000$ & 8 & $\mathrm{R}$ & $\mathrm{B}$ & Boufaroua et al., 2006 & 1 \\
\hline 609 & Tunesia & & El H'nach & 36.0694 & 9.4486 & A & 4.0 & 1099.8 & $1993-2006$ & 13 & $\mathrm{R}$ & B & Boufaroua et al., 2006 & 1 \\
\hline 610 & Tunesia & & Fid Ali & 35.7061 & 9.6028 & $\mathrm{~A}$ & 4.1 & 2053.6 & $1993-2004$ & 11 & $\mathrm{R}$ & $\mathrm{B}$ & Boufaroua et al., 2006 & 0 \\
\hline 611 & Tunesia & & Es Séghir & 36.4857 & 10.6847 & $\mathrm{~A}$ & 4.3 & 148.7 & $1994-2004$ & 10 & $\mathrm{R}$ & $\mathrm{B}$ & Boufaroua et al., 2006 & 1 \\
\hline 612 & Tunesia & & Brahim Zaher & 35.5428 & 9.2433 & $\mathrm{~A}$ & 4.6 & 1252.3 & $1994-1999$ & 5 & $\mathrm{R}$ & B & Boufaroua et al., 2006 & 1 \\
\hline 613 & Tunesia & & Baouejer & 35.5853 & 8.8658 & $\mathrm{~A}$ & 4.9 & 408.4 & $1993-2000$ & 7 & $\mathrm{R}$ & $\mathrm{B}$ & Boufaroua et al., 2006 & 0 \\
\hline 614 & Tunesia & & Janet & 35.8729 & 9.1924 & $\mathrm{~A}$ & 5.2 & 2532.4 & $1993-2003$ & 10 & $\mathrm{R}$ & $\mathrm{B}$ & Boufaroua et al., 2006 & 1 \\
\hline 615 & Tunesia & & M'Rira & 35.6094 & 8.4769 & A & 6.1 & 664.8 & $1993-2006$ & 13 & $\mathrm{R}$ & $\mathrm{B}$ & Boufaroua et al., 2006 & 1 \\
\hline 616 & Tunesia & & Abdeladim & 35.2169 & 8.5506 & $\mathrm{~A}$ & 6.4 & 197.4 & $1993-2006$ & 13 & $\mathrm{R}$ & $\mathrm{B}$ & Boufaroua et al., 2006 & 1 \\
\hline 617 & Tunesia & & Sadine2 & 35.7989 & 9.0795 & $\mathrm{~A}$ & 6.5 & 2437.4 & $1992-2000$ & 8 & $\mathrm{R}$ & $\mathrm{B}$ & Boufaroua et al., 2006 & 1 \\
\hline 618 & Tunesia & & Arara & 35.3689 & 8.4015 & A & 7.1 & 2546.9 & $1993-2002$ & 9 & $\mathrm{R}$ & B & Boufaroua et al., 2006 & 1 \\
\hline 619 & Tunesia & & Echar & 35.5513 & 8.6792 & $\mathrm{~A}$ & 9.2 & 262.5 & $1993-1999$ & 6 & $\mathrm{R}$ & $\mathrm{B}$ & Boufaroua et al., 2006 & 1 \\
\hline 620 & Tunesia & & El Gouazine & 35.9083 & 9.7036 & $\mathrm{~A}$ & 18 & 168 & $1993-2006$ & 13 & $\mathrm{R}$ & $\mathrm{B}$ & Boufaroua et al., 2006 & 1 \\
\hline 621 & Tunesia & Oued Chiba & Chiba & 36.6988 & 10.7716 & A & 64 & 4220 & N.A. & 12 & $\mathrm{R}$ & B & $\begin{array}{c}\text { Ghorbel and Claude, } \\
1977 \\
\end{array}$ & 1 \\
\hline 622 & Tunesia & Oued Kasseb & Kasseb & 36.7664 & 8.9933 & A & 101 & 5070 & N.A. & 8 & $\mathrm{R}$ & $\mathrm{B}$ & $\begin{array}{c}\text { Ghorbel and Claude, } \\
1977\end{array}$ & 1 \\
\hline 623 & Tunesia & Oued Lakhmess & Lakhmess & 35.9971 & 9.4775 & A & 131 & 2865 & N.A. & 9 & $\mathrm{R}$ & $\mathrm{B}$ & $\begin{array}{c}\text { Ghorbel and Claude, } \\
1977 \\
\end{array}$ & 1 \\
\hline 624 & Tunesia & & Nebaana & 36.0524 & 9.8514 & A & 855 & 2300 & N.A. & 10 & $\mathrm{R}$ & $\mathrm{B}$ & $\begin{array}{c}\text { Ghorbel and Claude, } \\
1977 \\
\end{array}$ & 1 \\
\hline 625 & Tunesia & Oued Mellegue & Mellègue & 36.3110 & 8.6873 & $\mathrm{~B}$ & 10300 & 695 & N.A. & 21 & $\mathrm{R}$ & $\mathrm{B}$ & $\begin{array}{c}\text { Ghorbel and Claude, } \\
1977 \\
\end{array}$ & 1 \\
\hline 626 & Tunesia & Rhezela & Rhezela & 37.0540 & 9.5403 & $\mathrm{~A}$ & 48 & 1900 & $1984-? ?$ & N.A. & $\mathrm{R}$ & B & Lahlou, 1996 & 1 \\
\hline
\end{tabular}




\begin{tabular}{|c|c|c|c|c|c|c|c|c|c|c|c|c|c|c|}
\hline ID & Country & $\begin{array}{c}\text { River/Catchment } \\
\text { Name }\end{array}$ & $\begin{array}{l}\text { Measuring } \\
\text { location }\end{array}$ & Lat $\left({ }^{\circ}\right)$ & Lon $\left(^{\circ}\right)$ & $\begin{array}{l}\text { Coord. } \\
\text { Quality }\end{array}$ & $\mathbf{A}\left(\mathbf{k m}^{2}\right)$ & $\underset{\left(\mathbf{t} / \mathbf{k m}^{2} / \mathbf{y}\right)}{\mathbf{S Y}}$ & MP & $\begin{array}{c}\text { MP } \\
\text { length } \\
(\mathbf{y})\end{array}$ & Type & $\begin{array}{c}\text { Data } \\
\text { Quality }\end{array}$ & Reference & GIS \\
\hline & & & & & & & & & & & & & & \\
\hline 627 & Tunesia & & Masri & 36.5808 & 10.3097 & $\mathrm{C}$ & 53 & 4426.6 & N.A. & N.A. & $\mathrm{R}$ & B & Lahlou, 1996 & 0 \\
\hline 628 & Tunesia & Bezik & Bezik & 36.7239 & 10.6348 & A & 84 & 2430 & 1960 - ?? & N.A. & $\mathrm{R}$ & B & Lahlou, 1996 & 1 \\
\hline 629 & Tunesia & & Lebna & 36.7521 & 10.9075 & A & 199 & 2906 & $1986-? ?$ & N.A. & $\mathrm{R}$ & B & Lahlou, 1996 & 1 \\
\hline 630 & Tunesia & Kebir & Kebir & 36.2458 & 9.7844 & A & 271 & 844 & $1925-? ?$ & N.A. & $\mathrm{R}$ & B & Lahlou, 1996 & 1 \\
\hline 631 & Tunesia & Bou Hertma & Bou Hertma & 36.3991 & 8.7940 & $\mathrm{C}$ & 390 & 1600 & $1976-? ?$ & N.A. & $\mathrm{R}$ & B & Lahlou, 1996 & 0 \\
\hline 633 & Tunesia & & Siliana & 36.1462 & 9.3608 & $\mathrm{~A}$ & 1040 & 4035.9 & N.A. & N.A. & $\mathrm{R}$ & B & Lahlou, 1996 & 1 \\
\hline 634 & Tunesia & Marguellil & Marguellil & 35.5667 & 9.7392 & $\mathrm{~A}$ & 1120 & 1500 & $1990-? ?$ & N.A. & $\mathrm{R}$ & B & Lahlou, 1996 & 1 \\
\hline 635 & Tunesia & & Bir M'cherga & 36.5152 & 10.0135 & $\mathrm{~A}$ & 1263 & 350 & N.A. & N.A. & $\mathrm{R}$ & $\mathrm{B}$ & Lahlou, 1996 & 1 \\
\hline 636 & Tunesia & & Sidi Saad & 35.3669 & 9.6723 & $\mathrm{~B}$ & 8950 & 813.6 & N.A. & N.A. & $\mathrm{R}$ & B & Lahlou, 1996 & 1 \\
\hline 637 & Tunesia & & Sidi Salem & 36.6507 & 9.3901 & B & 18250 & 234.2 & N.A. & N.A. & $\mathrm{R}$ & B & Lahlou, 1996 & 1 \\
\hline 638 & Tunesia & & Hadada & 35.8387 & 9.1313 & B & 4.7 & 1060.8 & N.A. & N.A. & $\mathrm{R}$ & B & $\begin{array}{l}\text { Lahlou, 1996; Boufarou } \\
\text { et al., } 2006\end{array}$ & 1 \\
\hline 639 & Tunesia & Miliane (Meliane) & near outlet & 36.7636 & 10.2966 & B & 2000 & 450 & N.A. & N.A. & GS & $\mathrm{U}$ & $\begin{array}{l}\text { Milliman and Fansworth, } \\
2011\end{array}$ & 1 \\
\hline 641 & Uganda & Muzira & Muzira & -0.4787 & 30.3359 & A & 99 & 164 & $\begin{array}{c}1 \text { June } 2009-31 \\
\text { May } 2010\end{array}$ & 1 & GS & $\mathrm{C}$ & $\begin{array}{l}\text { Ryken, 2010; Ryken et } \\
\text { al., } 2013\end{array}$ & 1 \\
\hline 642 & Uganda & Buhweju & Nyakambu & -0.4318 & 30.4597 & A & 182 & 68 & $\begin{array}{c}1 \text { June } 2009-31 \\
\text { May } 2010\end{array}$ & 1 & GS & $\mathrm{C}$ & $\begin{array}{l}\text { Ryken, 2010; Ryken et } \\
\text { al., } 2013\end{array}$ & 1 \\
\hline 643 & Uganda & Kandenkye & Rwamunena & -0.6749 & 30.2783 & A & 359 & 23 & $\begin{array}{c}1 \text { June } 2009-31 \\
\text { May } 2010\end{array}$ & 1 & GS & $\mathrm{C}$ & $\begin{array}{l}\text { Ryken, 2010; Ryken et } \\
\text { al., } 2013\end{array}$ & 1 \\
\hline 644 & Uganda & Koga & Koga & -0.5788 & 30.4506 & A & 379 & 25 & $\begin{array}{c}1 \text { June } 2009-31 \\
\text { May } 2010\end{array}$ & 1 & GS & $\mathrm{C}$ & $\begin{array}{l}\text { Ryken, 2010; Ryken et } \\
\text { al., } 2013\end{array}$ & 1 \\
\hline 645 & Uganda & Itojo & Ndaija & -0.7233 & 30.3502 & A & 683 & 53 & $\begin{array}{l}1 \text { June } 2009-31 \\
\text { May } 2010\end{array}$ & 1 & GS & $\mathrm{C}$ & $\begin{array}{c}\text { Ryken, 2010; Ryken et } \\
\text { al., } 2013\end{array}$ & 1 \\
\hline 646 & Uganda & Bujaga & Nyeihanga & -0.6825 & 30.3894 & A & 859 & 41 & $\begin{array}{l}1 \text { June } 2009-31 \\
\text { May } 2010\end{array}$ & 1 & GS & $\mathrm{C}$ & $\begin{array}{c}\text { Ryken, 2010; Ryken et } \\
\text { al., } 2014\end{array}$ & 1 \\
\hline 647 & Uganda & Mijera & Rugarama & -0.6313 & 30.4463 & A & 1092 & 60 & $\begin{array}{c}1 \text { June } 2009-31 \\
\text { May } 2010\end{array}$ & 1 & GS & $\mathrm{C}$ & $\begin{array}{c}\text { Ryken, 2010; Ryken et } \\
\text { al., 2015 }\end{array}$ & 1 \\
\hline 648 & Uganda & Nyamitanga & Ruharo & -0.6153 & 30.6868 & A & 2121 & 94 & $\begin{array}{l}1 \text { June } 2009-31 \\
\text { May } 2010\end{array}$ & 1 & GS & $\mathrm{C}$ & $\begin{array}{l}\text { Ryken, 2010; Ryken et } \\
\text { al., } 2016\end{array}$ & 1 \\
\hline 649 & Zambia & Izi & Mbete village & -8.8115 & 31.0413 & A & 54 & 8.3 & $\begin{array}{c}1 \text { Oct } 1998-30 \text { Sept } \\
1999\end{array}$ & 1 & GS & $\mathrm{C}$ & Sichingabula, 2000 & 1 \\
\hline 650 & Zambia & Lucheche & Kawe village & -8.8128 & 31.1516 & B & 312 & 1.2 & $\begin{array}{c}1 \text { Oct } 1998-30 \text { Sept } \\
1999\end{array}$ & 1 & GS & $\mathrm{C}$ & Sichingabula, 2000 & 1 \\
\hline
\end{tabular}




\begin{tabular}{|c|c|c|c|c|c|c|c|c|c|c|c|c|c|}
\hline ID & Country & $\begin{array}{c}\text { River/Catchment } \\
\text { Name }\end{array}$ & $\begin{array}{c}\text { Measuring } \\
\text { location }\end{array}$ & Lat $\left(^{\circ}\right)$ & Lon $\left(^{\circ}\right)$ & $\begin{array}{c}\text { Coord. } \\
\text { Quality }\end{array}$ & A $\left(\mathbf{k m}^{2}\right)$ & $\begin{array}{c}\text { SY } \\
\left(\mathbf{t} / \mathrm{km}^{2} / \mathbf{y}\right)\end{array}$ & MP & $\begin{array}{c}\text { MP } \\
\text { length } \\
(\mathbf{y})\end{array}$ & $\begin{array}{c}\text { Type } \\
\text { Quality }\end{array}$ & $\begin{array}{c}\text { Data } \\
\text { Reference }\end{array}$ \\
\hline
\end{tabular}

\begin{tabular}{|c|c|c|c|c|c|c|c|c|c|c|c|c|c|c|}
\hline 651 & Zambia & Lunzua & Simumbele village & -8.7720 & 31.1478 & A & 686 & 14 & \begin{tabular}{|c|}
1 Oct $1998-30$ Sept \\
1999
\end{tabular} & 1 & GS & $\mathrm{C}$ & Sichingabula, 2000 & 1 \\
\hline 652 & Zambia & Upper Kaleya & near Mazabuka & -16.1833 & 28.0333 & B & 63 & 21 & $1997-2000$ & 3 & GS & $\mathrm{A}$ & Walling et al., 2001 & 1 \\
\hline 653 & Zimbabwe & & Kariba & -16.5122 & 28.7661 & B & 514892 & 77.2 & N.A. & N.A. & $\mathrm{R}$ & $\mathrm{C}$ & Bolton, 1984 & 0 \\
\hline 654 & Zimbabwe & Gwai & outlet & -17.9800 & 26.9256 & B & 14400 & 150 & N.A. & 1 & GS & $\mathrm{U}$ & $\begin{array}{c}\text { Dedkov and Mozzherin, } \\
1984\end{array}$ & 0 \\
\hline 655 & Zimbabwe & & Nyaru Shangwe & -20.2212 & 30.2836 & A & 108 & 704 & $1973-1984$ & 12 & $\mathrm{R}$ & $\mathrm{U}$ & FAO, 2008 & 1 \\
\hline 656 & Zimbabwe & & Makaholi & -19.8485 & 30.7674 & A & 154 & 10 & $1970-1984$ & 15 & $\mathrm{R}$ & $\mathrm{U}$ & FAO, 2008 & 1 \\
\hline 657 & Zimbabwe & & Chikwedziwa & -21.6863 & 31.3184 & A & 205 & 45 & $1950-1984$ & 35 & $\mathrm{R}$ & $\mathrm{U}$ & FAO, 2008 & 1 \\
\hline 659 & Zimbabwe & & Mazoe & -17.5287 & 30.9943 & A & 348 & 64 & $1920-1984$ & 65 & $\mathrm{R}$ & $\mathrm{U}$ & FAO, 2008 & 1 \\
\hline 660 & Zimbabwe & & Upper Umgusa & -20.0567 & 28.5739 & A & 401 & 48 & $1946-1984$ & 39 & $\mathrm{R}$ & $\mathrm{U}$ & FAO, 2008 & 1 \\
\hline 661 & Zimbabwe & & $\begin{array}{l}\text { Mchabisa (or: } \\
\text { Mchabisa Sheet) }\end{array}$ & -21.0375 & 29.3689 & $\mathrm{C}$ & 435 & 88 & $1942-1984$ & 43 & $\mathrm{R}$ & $\mathrm{U}$ & FAO, 2008 & 0 \\
\hline 662 & Zimbabwe & & Siya & -20.2470 & 31.6187 & A & 518 & 300 & $1977-1984$ & 8 & $\mathrm{R}$ & $\mathrm{U}$ & FAO, 2008 & 1 \\
\hline 663 & Zimbabwe & & Ngezi & -18.7481 & 30.3937 & A & 1399 & 65 & $1944-1984$ & 41 & $\mathrm{R}$ & $\mathrm{U}$ & FAO, 2008 & 1 \\
\hline 664 & Zimbabwe & & Manjirenji & -20.6007 & 31.5985 & A & 1536 & 319 & $1966-1984$ & 19 & $\mathrm{R}$ & $\mathrm{U}$ & FAO, 2008 & 1 \\
\hline 665 & Zimbabwe & & Bangala & -20.6888 & 31.2207 & A & 1839 & 232 & $1963-1984$ & 22 & $\mathrm{R}$ & $\mathrm{U}$ & FAO, 2008 & 0 \\
\hline 667 & Zimbabwe & & Kyle & -20.2234 & 30.9826 & A & 3989 & 60 & $1961-1984$ & 24 & $\mathrm{R}$ & $\mathrm{U}$ & FAO, 2008 & 1 \\
\hline 668 & Zimbabwe & & Rinette Weir & -21.2854 & 30.6321 & A & 6000 & 270 & N.A. & 9 & $\mathrm{R}$ & $\mathrm{U}$ & Kabell, 1984 & 1 \\
\hline 669 & Zimbabwe & & Jotsholo Weir & -18.6935 & 27.5841 & B & 14860 & 110 & N.A. & 6 & $\mathrm{R}$ & $\mathrm{U}$ & Kabell, 1984 & 1 \\
\hline 670 & Zimbabwe & & Chatikobu & -19.7166 & 32.0834 & A & 2.4 & 421 & N.A. & N.A. & $\mathrm{R}$ & B & Van den wall Bake, 1986 & 1 \\
\hline 671 & Zimbabwe & & Nyamembwe & -16.5225 & 31.5474 & A & 7.0 & 410 & N.A. & N.A. & $\mathrm{R}$ & B & Van den wall Bake, 1986 & 1 \\
\hline 672 & Zimbabwe & & Nyamasa & -17.1799 & 32.9265 & $\mathrm{~B}$ & 7.1 & 157 & N.A. & N.A. & $\mathrm{R}$ & $\mathrm{B}$ & Van den wall Bake, 1986 & 1 \\
\hline 673 & Zimbabwe & & Masvaru & -19.2490 & 32.6049 & $\mathrm{C}$ & 8.6 & 469 & N.A. & N.A. & $\mathrm{R}$ & $\mathrm{B}$ & Van den wall Bake, 1986 & 0 \\
\hline 674 & Zimbabwe & & Demba & -20.3706 & 31.5966 & $\mathrm{C}$ & 10 & 332 & N.A. & N.A. & $\mathrm{R}$ & $\mathrm{B}$ & Van den wall Bake, 1986 & 0 \\
\hline 675 & Zimbabwe & & Mabgwe Matema & -20.2881 & 29.7295 & A & 28 & 80 & N.A. & N.A. & $\mathrm{R}$ & B & Van den wall Bake, 1986 & 1 \\
\hline 676 & Zimbabwe & & Masunswa & -17.0828 & 32.1347 & $\mathrm{C}$ & 29 & 348 & N.A. & N.A. & $\mathrm{R}$ & $\mathrm{B}$ & Van den wall Bake, 1986 & 0 \\
\hline 677 & Zimbabwe & & Banga & -20.8387 & 31.0724 & $\mathrm{C}$ & 38 & 12 & N.A. & N.A. & $\mathrm{R}$ & $\mathrm{B}$ & Van den wall Bake, 1986 & 0 \\
\hline 678 & Zimbabwe & & Mapanzure & -20.7671 & 31.1529 & $\mathrm{~A}$ & 43 & 526 & N.A. & N.A. & $\mathrm{R}$ & $\mathrm{B}$ & Van den wall Bake, 1986 & 1 \\
\hline 679 & Zimbabwe & & Dowe & -20.0896 & 31.9004 & $\mathrm{~A}$ & 52 & 306 & N.A. & N.A. & $\mathrm{R}$ & $\mathrm{B}$ & Van den wall Bake, 1986 & 1 \\
\hline 680 & Zimbabwe & & Ngwenya & -19.9171 & 28.8874 & A & 54 & 245 & N.A. & N.A. & $\mathrm{R}$ & B & Van den wall Bake, 1986 & 1 \\
\hline
\end{tabular}




\begin{tabular}{|c|c|c|c|c|c|c|c|c|c|c|c|c|c|c|}
\hline ID & Country & $\begin{array}{c}\text { River/Catchment } \\
\text { Name }\end{array}$ & $\begin{array}{c}\text { Measuring } \\
\text { location }\end{array}$ & Lat $\left({ }^{\circ}\right)$ & Lon $\left(^{\circ}\right)$ & $\begin{array}{l}\text { Coord. } \\
\text { Quality }\end{array}$ & $\mathbf{A}\left(\mathbf{k m}^{2}\right)$ & $\underset{\left(\mathbf{t} / \mathbf{k m}^{2} / \mathbf{y}\right)}{\mathbf{S Y}}$ & MP & $\begin{array}{c}\text { MP } \\
\text { length } \\
\text { (y) }\end{array}$ & Type & $\begin{array}{c}\text { Data } \\
\text { Quality }\end{array}$ & Reference & GIS \\
\hline & 7imbohwo & & ( ) & & & $C$ & 50 & 01 & No & 1 & & & , & ${ }_{0}$ \\
\hline 682 & Zimbabwe & & Questeds & -20.4311 & 27.8320 & $\mathrm{~A}$ & 61 & 84 & N.A. & N.A. & $\mathrm{R}$ & $\mathrm{B}$ & Van den wall Bake, 1986 & 1 \\
\hline
\end{tabular}

